$$
\text { UNIVERSIDADE DE SÃO PAULO }
$$

FACULDADE DE FILOSOFIA, LETRAS E CIÊNCIAS HUMANAS

TATIANE REGHINI DE MATTOS

\title{
As vozes narrativas de Pepetela: A geração da utopia e
} Predadores

São Paulo 
TATIANE REGHINI DE MATTOS

\section{As vozes narrativas de Pepetela: A geração da utopia e Predadores}

Dissertação apresentada ao programa de Estudos Comparados de Literaturas de Língua Portuguesa da Faculdade de Filosofia, Letras e Ciências Humanas da Universidade de São Paulo, para obtenção do título de Mestre sob a orientação da Prof ${ }^{a}$. Dra. Rejane Vecchia da Rocha e Silva.

São Paulo 
Autorizo a reprodução e divulgação total ou parcial deste trabalho, por qualquer meio convencional ou eletrônico, para fins de estudo e pesquisa, desde que citada a fonte.

Catalogação da Publicação

Faculdade de Filosofia, Letras e Ciências Humanas da Universidade de São Paulo

MATTOS, Tatiane Reghini de.

As vozes narrativas de Pepetela: A geração da utopia e Predadores / Tatiane Reghini de Mattos

Rejane Vecchia da Rocha e Silva. - São Paulo, 2013.

$113 \mathrm{f}$.

Dissertação (Mestrado) - Universidade de São Paulo, 2013.

1. Pepetela. 2. Literatura. 2. Angola. 3. História 4. Ideologia

I. Título: As vozes narrativas de Pepetela: A geração da utopia e Predadores 
nome: MATTOS, Tatiane Reghini de

título: As vozes narrativas de Pepetela: A geração da utopia e Predadores

Dissertação apresentada à Faculdade de Filosofia, Letras e Ciências Humanas para obtenção do título de Mestre.

Aprovada em:

Banca examinadora

Prof. Dr Instituição:

Julgamento:

Assinatura:

Prof. Dr. Instituição:

Julgamento:

Assinatura:

Prof. Dr. Instituição:

Julgamento: Assinatura: 
A literatura e essa preocupação social apareceram ligadas em mim desde o princípio, portanto, agora, é um bocado tarde para mudar, há é que aperfeiçoar isso...

PEPETELA 
Agradecimentos:

Muito especialmente à Rejane Vecchia, pela orientação e amizade generosas.

À Margarete Reghini e ao Claudio Mattos.

Ao Guilherme Vieira e à Carol Takeda; ao Otávio Almeida, à Andrea Guerra e à Gabriela Viacava.

A todos os amigos que me ajudaram a escrever esta dissertação. 


\section{RESUMO}

MATTOS, T. R. As vozes narrativas de Pepetela : A geração da utopia e Predadores. 2013. 113 f. Dissertação (Mestrado) - Faculdade de Filosofia, Letras e Ciências Humanas. Departamento de Letras Clássicas e Vernáculas, Universidade de São Paulo, São Paulo, 2013.

Esta pesquisa tem como objetivo a realização de uma análise comparativa entre as vozes que narram os romances $A$ geração da utopia e Predadores, do escritor angolano Pepetela, a partir, principalmente, do mapeamento das consonâncias e dissonâncias entre as vozes, possibilitadas pelas condições históricas e ideológicas presentes em suas composições.

Palavras-chave: Pepetela, literatura, Angola, narrador, história, ideologia. 


\section{ABSTRACT}

MATTOS, T. R. The narrative voices of Pepetela: A geração da utopia and Predadores. 2013. 113 f. Dissertação (Mestrado) - Faculdade de Filosofia, Letras e Ciên Humanas. Departamento de Letras Clássicas e Vernáculas, Universidade de São Pa São Paulo, 2013.

The aim of the present research is to provide a comparative analysis between the narrative voices of the novels A geração da utopia and Predadores, written by the Angolan writer Pepetela. The comparison is mainly based on the mapping of the consonances and dissonances among these voices, allowed by historical and ideological conditions existent in his works.

Key Words: Pepetela, literature, Angola, narrator, history, ideology. 


\section{Sumário}

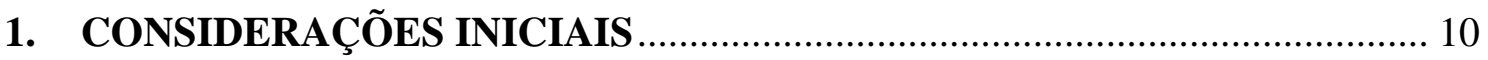

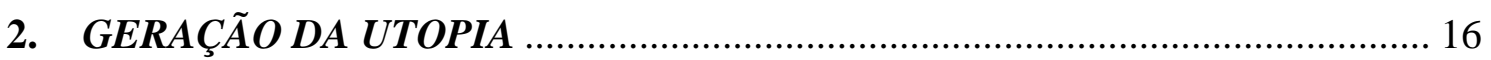

2.1 A utopia latente - a aproximação de Sara (Nascimento do projeto e construção utópica)

2.2 A guerra desfazendo as ilusões - o narrador e Mundial ........................... 30

2.3 O último refúgio - foco narrativo em Aníbal ............................................. 36

2.4 Estilhaços da realidade - Malongo ao centro ....................................... 42

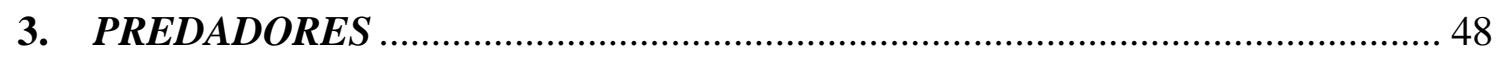

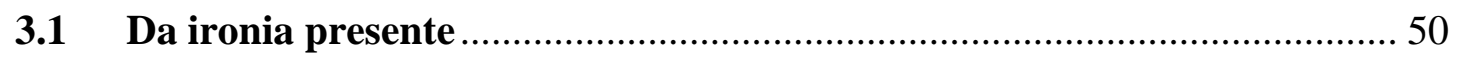

3.2 A ironia latente: o narrador que acompanha Vladimiro Caposso ............ 55

3.3 Ironia silenciada: a presença de Sebastião Lopes e Nacib ........................ 61

3.4 A ironia sobreposta ao enredo: o diálogo autor implícito e leitor ............. 67

4. NO CERNE DA COMPARAÇÃO: APORTE TEÓRICO PARA ANÁLISE

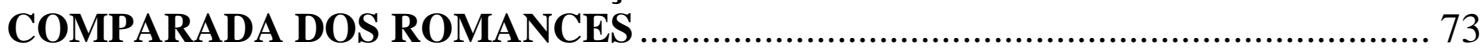

4.1 As vozes que contam: posição do narrador e presença do autor implícito73

4.2 Vozes dissonantes: a consolidação das vozes enviesadas por eventos

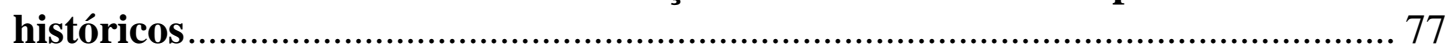

4.3 Vozes consonantes: a presença da dimensão ideológica ........................... 91

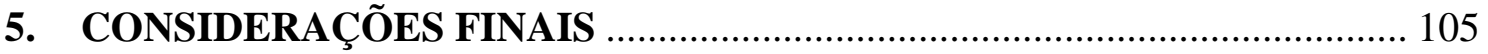

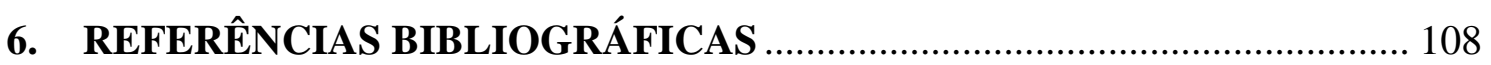




\section{CONSIDERAÇÕES INICIAIS}

A presente dissertação tem o interesse de analisar a questão do foco narrativo a partir dos romances A geração da utopia e Predadores, ambos escritos pelo escritor angolano Pepetela. Nascido em Benguela, em 1941, Artur Carlos Maurício Pestana dos Santos apresenta como um dos leitmotiv do seu projeto literário a necessidade de aliar dois campos do conhecimento humano, isto é, a literatura, dentro de suas demarcadas especificidades, e a história, que emerge no cenário literário a partir de um olhar que procura contar as experiências da vida em Angola. No romance A geração da utopia, o recorte cronológico proposto pelo autor focalizará todo o processo de ascensão da luta de libertação, a guerra propriamente dita e as duas décadas posteriores a 1975, abarcando, assim, quatro décadas da história do país. Em Predadores, há uma alternância proposta relativamente ao tempo do romance e que se organiza entre as décadas de 1970, 1980, 1990 e o início dos anos 2000. É possível perceber, portanto, comparativamente, o interesse em abarcar longos períodos da história do país em que se revele uma percepção apurada dos movimentos dessa história, destacando, sobretudo, as relações sociais desencadeadas pela organização política e econômica em distintas décadas.

O engajamento do escritor, portanto, remete à sua militância política e dela não se dissocia. Pepetela foi recrutado para a luta armada anticolonial pelo MPLA (Movimento Popular de Libertação de Angola) em 1969, deslocando-se de Argel ${ }^{1}$, onde já estava exilado após a fuga de Lisboa, para Cabinda ${ }^{2}$, local onde participou de sua primeira Frente de Guerrilha. Lá escreveu Muana Puó (1969), considerado por alguns críticos como seu primeiro romance, e Mayombe (1971), que se consagraria como uma das obras mais marcantes de sua produção literária. Passados três anos, foi para Frente Leste e escreveu As aventuras de ngunga e parte do capítulo que mais tarde comporia $A$ chana, de A geração da utopia.

\footnotetext{
${ }^{1}$ Após sair de Lisboa, Pepetela segue para Paris e, em 1963, fixa-se em Argel; a Argélia, a essa altura, já tinha conquistado sua independência da França, e contava com a presença de um grupo de angolano. Lá, o escritor forma-se em Sociologia.

${ }^{2}$ Enclave ao norte do país, rico em petróleo.
} 
Em 1974, Pepetela assumiu o comando da frente de guerra contra a FNLA (Força Nacional de Libertação de Angola), em Benguela, e dois anos depois assumiu o cargo de vice-ministro da Educação, já no primeiro governo de conotações marxistasleninistas $^{3}$ do MPLA, presidido por Agostinho Neto. Nesse cargo, permaneceu até 1982 e durante esse tempo escreveu A corda (1976), A revolta da casa dos ídolos (1977) e iniciou $O$ cão e os caluandas (1979). Sua trajetória política está, portanto, intrinsicamente ligada à sua trajetória artística e, muito embora $A$ geração da utopia e Predadores tenham sido escritos depois de findada sua atuação pelo MPLA, ainda assim ecoam nessas obras os vários processos históricos relativos à história angolana, mantendo características fundamentais do projeto literário inicial de Pepetela.

Se, no entanto, sua participação ativa como agente histórico resulta e/ou acompanha seu desenvolvimento artístico, torna-se plausível que tenhamos incidindo na obra literária seus posicionamentos políticos ao longo de seu percurso. Entendemos que tal incidência se dará especialmente no que tange a questão do ponto de vista (ou foco narrativo), evidenciado principalmente a partir de duas vozes que preponderam na sua oratória: seus autores implícitos e seus narradores.

No tocante à distinção entre essas duas entidades narrativas, narrador e autor implícito, buscaremos apoio à teoria de Wayne Booth, a qual, destaquemos desde já, estabelece diferenciações entre ambos. Para Booth, o autor implícito é uma espécie de alter ego do próprio autor e "está presente em todos os discursos de qualquer personagem a quem tenha sido conferido o emblema de credibilidade, seja de que modo for” (BOOTH, 1980, p. 37). Já o narrador é mais uma criação desse autor implícito, tanto quanto as personagens que compõem o romance, e "é geralmente aceito como o "eu" da obra que, afinal, não passa de mais um dos elementos criados pelo autor implícito e pode dele ser diferenciado por amplas ironias". (BOOTH, 1980, p. 90).

Estabelecendo, assim, essa distinção, podemos notar que nas duas obras que compõem o corpus ficcional desta dissertação manifestam-se autor implícito e narrador dissociando-se por vezes, e assumindo, ora um ora outro, a condução da voz narrativa. Não obstante, torna-se essencial que frisemos as distinções que entre eles se estabelecem e que parecem apontar para a imersão/dimensão ideológica à qual está

\footnotetext{
${ }^{3}$ Tal referência está ligada às lideranças que seguiram a cartilha de Joseph Stalin.
} 
circunscrito esse autor implícito. Assim sendo, temos que enquanto em A geração da utopia o narrador é interceptado por esse autor que poucas vezes autonomamente se manifesta, colocando-se numa esfera para além da voz narrativa, em Predadores tal intercepção do narrador executada pelo autor implícito passa a ser parte estruturante da voz que narra, criando um diálogo direto com o leitor e deflagrando um tom irônico que em A geração ainda estava em gestação.

Em linhas gerais, A geração da utopia, publicada em 1992, traça um panorama da geração que presenciou ou participou da luta de libertação de Angola e do conseguinte governo que se instaura no país independente. Através de quatro personagens que serão uma espécie de duplo do foco narrativo em terceira pessoa, são revelados os caminhos dessa geração que sonhava com uma Angola liberta do inimigo colonial e progenitora de uma igualdade social, calcada nos sonhos socialistas latentes da década de 1960. Divida também em quatro partes, a narração compreende um período de tempo que vai de 1961, época do início da elaboração da luta armada anticolonial, até 1991, período em que acordos para a realização de eleições parecia garantir em Angola o fim da guerra que se estendeu de 1977 a 2002. Com saltos de aproximadamente uma década entre os capítulos que compõem o romance, o leitor se encontra com as mesmas personagens a viverem em diferentes contextos políticos, sociais e históricos angolanos. Nesse percurso, acompanhamos a ascensão de uma reflexão profundamente crítica que se revelará ora pelos narradores, ora pelo autor implícito (que por vezes se manifestará explicitamente), sobre os rumos políticos do país e em que se observa a ascensão e queda de uma expectativa ainda utópica que ambicionava um país independente e uma identidade nacional constituída no processo de libertação até a descompassada realidade vigente no pós-independência.

Treze anos depois, Pepetela publica Predadores. O contexto apresentado aqui é, conforme nos alerta o título, de uma sociedade entregue aos mandos e desmandos de homens predatórios que agem em benefício próprio, enquanto afundam o país inteiro na miséria e na falta de recursos, com suas investidas violentas para obter poder e acumular riqueza. O espaço de tempo compreendido na obra vai de novembro de 1974 a janeiro de 2005, ou seja, do momento em que se inicia o cessar fogo e começam os acordos 
para a independência até poucos anos depois do fim da guerra civil angolana ${ }^{4}$. Embora aqui o narrador também estabeleça o seu duplo com diversas personagens, é de Vladimiro Caposso que estará próximo na maior parte do tempo narrativo. Nascido pobre, Caposso aprende a usar todos os artifícios necessários para ascender numa política que, após a independência, finca-se na corrupção e nas regras feitas por aqueles que ocupam o poder. Vladimiro torna-se um homem rico e poderoso, cujos mandos e desmandos contribuem para uma construção social cada vez mais desigual. A narrativa não é linear; o tempo se organiza a partir de uma sistemática alternância à mercê das escolhas do autor implícito que, por sua vez, intromete-se na narrativa frequentemente chamando o leitor a conversa.

Se em comum as narrativas apresentam essa dimensão polifônica do foco narrativo, respaldada em personagens ou, por vezes, na manifestação explícita do autor implícito, é válido ressaltar que outras características reverberam num processo de espelhamento de certos elementos narrativos que apontam para um dialogismo entre narradores e autores implícitos de ambos romances. Nesse sentido, podemos destacar nos dois romances, por exemplo, o surgimento de uma burguesia política angolana - que acumula capital aproveitando-se de benefícios fornecidos por servidores corruptos do Estado que se apresenta no final de A geração da utopia e se tornará central para a narrativa de Predadores. Assim sendo, Malongo que é o representante dessa nova classe em $A$ geração, terá seu retrato refletido em Vladimiro Caposso, de Predadores. Essa reverberação de um tema tratado de maneira restrita (correspondente a um capítulo) em outro tratado de maneira ampla (o romance todo) permite, a nosso ver, que se estabeleça um diálogo entre os autores implícitos dessas obras. Da mesma maneira, características da voz narrativa que se levantam em $A$ geração da utopia ao tratar esse tema resplandecerão, tomando novas dimensões em Predadores.

Temos, assim, algumas características narrativas que começam a ser fecundadas em A geração da utopia reaparecendo em Predadores, e bem mais intensificadas. Caso extremamente significativo desse processo é, por exemplo, o uso da ironia, que

\footnotetext{
${ }^{4}$ Pepetela, em entrevistas recentes, tem colocado em questão o termo guerra civil, chamando a atenção para o que foram as especificidades dessa guerra que aconteceu em Angola entre 1976 a 2002. Valeria destacar que os confrontos colocam em choque organizações políticas internas, no caso, o MPLA e a UNITA, mas, frisemos, tais confrontos encontraram apoio de países que ambicionavam intervir na política-econômica interna. A década de 1970 atravessava ainda a Guerra Fria e isso merece e deve ser considerado no conjunto dos conflitos internos.
} 
enquanto naquele romance é ensaiada a partir da aproximação do foco narrativo dos vilões da história (capítulo 2 e 4 - nos quais o narrador acompanha, respectivamente, Vítor e Malongo), neste ressurge com um caráter agudo, precipitando-se numa crítica negativa mais sagaz e contundente, advinda da aproximação do narrador com o antiherói Caposso.

Nesse contexto, é válido apontar ainda para o fato de que esse diálogo entre as vozes das obras citadas parece ser oriundo de um romance anterior a esses, cuja temática também é o desenvolvimento da luta armada, mas que, no entanto, não está no escopo deste trabalho. Escrito em 1972, embora publicado apenas em 1982, Mayombe apresenta em seu enredo as experiências vividas por certo grupo de guerrilheiros na floresta de Cabinda, relatando seus medos, expectativas, ambições, dificuldades, renúncias e necessidades: a luta individual de cada personagem por uma causa coletiva, a saber a independência e a construção de uma nação com princípios socialistas. Dividido em cinco capítulos mais o epílogo, o romance se apresenta sob dois planos narrativos. O primeiro representado por um narrador em terceira pessoa, mais intimamente ligado ao modo de ver do seu protagonista, o Comandante Sem Medo; e o segundo, realizado em primeira pessoa, numa espécie de voz concedida às personagens que fazem seus relatos.

Essa voz concedida, a qual Rita Chaves chama de democrática, abrolha sempre marcada textualmente na forma de itálico e está vinculada aos inícios de cada capítulo, cujo título, repetido inúmeras vezes - Eu, narrador sou... -, anuncia o nome do personagem que terá direito a voz, alimentando, dessa maneira, conforme nos alerta ABDALA Jr. (in CHAVES, 2009, p. 175) "o conjunto de uma totalidade dialógica sonhada pelo escritor”. Dessa forma, o autor implícito se manifesta nas articulações que executa entre o narrador e essas personagens, cujas vozes inauguram cada capítulo. Há, portanto, como podemos notar, uma espécie de ensaio da polifonia que se tornará preponderante em A geração da utopia e também estará presente em Predadores. Chamamos de ensaio porque se em Mayombe essa voz do narrador abre pontualmente espaço para outras vozes, diferenciando-se, no entanto, em A geração e Predadores, ela se engendra de maneira mais complexa, através do fluxo de consciência e, principalmente, do discurso indireto livre, que acabam por se tornar características marcantes de suas estruturas. E dessa maneira notamos que a utopia está para Mayombe 
e $A$ geração (no retrato da luta anticolonial), assim como a ironia está para $A$ geração e Predadores (no retrato do período do pós-independência).

Esse processo que parece amalgamar as obras aponta para uma alocação ideológica dos autores implícitos subscritos nelas, resultando em um intrínseco diálogo. Confiamos que esse diálogo da voz narrativa é resultante do processo ideológico marcado pelo contexto histórico, no qual o autor implícito se inscreve, submetendo o seu narrador. E residem nas características específicas de cada uma os fragmentos dessa resultante. É a partir desse ponto que chegamos à inter-relação entre literatura e história proposta por esta pesquisa.

Ainda que o tempo compreendido nas obras sofra uma variável, é notável que também sofra esse processo de espelhamento, expandindo-se, como pretendemos demonstrar. Podemos destacar que se em A geração da utopia o tempo retratado é do início da eclosão da guerra anticolonial até o momento em que houve no país um intervalo da guerra civil (gerada por disputas políticas internas, angariadas e intensificadas pelos interesses externos) para as primeiras eleições; em Predadores o tempo a ser contemplado é do pós-independência (correspondente ao capítulo 2 de $A$ geração) até o fim da guerra civil, numa Angola já imersa nos interesses neoliberais. Mayombe corresponde a parte desse tempo, mas não a seu todo. O tempo lá é o tempo de guerra de libertação, tendo como cenário um front de batalha de Cabinda. Tempo esse que corresponde também ao segundo capítulo de $A$ geração, mas que, no entanto, é retratado a partir de diferente pespectiva (sendo mais positiva naquele e mais negativa neste).

Temos, então, que a maneira como será retratado esse momento histórico do pósguerra colonial em cada uma das narrativas presentes nesta dissertação é singularizada pela perspectiva através da qual se conta a história. E, por sua vez, essa perspectiva, escolhida pelo autor implícito, acatada pelo narrador, revela, acreditamos, qual a proximidade desse autor implícito com o projeto político predominante no MPLA. Se as vozes narrativas presentes nas obras se reverberam, dialogando, e assumem novas posturas críticas, podemos admitir que ecoam mudanças ideológicas no processo do alter ego de Pepetela produzido na obra de refletir sobre o contexto histórico. 
Não obstante, nota-se que, embora ambos romances desvelem facetas negativas do MPLA, ressoam também em suas estruturas o comprometimento com o projeto inicial, outrora vislumbrado através da projeção utópica. Ainda que haja uma mudança de postura crítica, podemos observar na construção dessa voz narrativa e das personagens que tomam forma através dela a proeminência das características idealizadas como essenciais no projeto do MPLA para formação do novo país independente e, consequentemente, dos homens que formariam esse país.

Portanto, se há de fato uma ruptura ideológica do autor implícito com a ordem que se estabelece ao longo do enredo, ela parece ocorrer de maneira singular em cada um dos romances, compreendendo, todavia, uma parte do projeto e nunca o seu todo. E uma vez realizada dessa maneira, parece-nos importante averiguar de que forma ela se manifesta em cada uma das obras e o que elucida a partir da postura narrativa que assume. Cabe, portanto, realizarmos uma investigação que caminhe na perspectiva comparada para ver as imbricações entre ambas as obras, a seguir, entre ambas as obras e os processos históricos de Angola, e, por último, ambas as obras, a história presente nelas e o viés ideológico identificados nessa leitura.

\section{GERAÇÃO DA UTOPIA}

"Faz-se a utopia e nasce uma nação. Faz-se uma nação e perde-se um sonho" Rita Chaves ${ }^{5}$

Em 1991, Pepetela estabelece-se em Berlim com uma bolsa recebida do Serviço Alemão de Intercâmbio Universitário e escreve A geração da utopia. Passados dezesseis anos da conquista da Independência, o autor parece fazer, nesse romance, um balanço sobre os eventos ocorridos em Angola durante cerca de três décadas (19611992), ficcionalizando episódios cujos pontos fulcrais são identificáveis na história do país. Nesse livro, o escritor se propõe a retratar as facetas e contradições de uma geração que se predispôs a lutar por uma Angola independente, mas que também foi imprescindível nos primeiros passos do país no pós-independência.

\footnotetext{
${ }^{5}$ CHAVES, Rita. Via Atlântica, 1999.
} 
Dentre as características marcantes da obra pepeteliana, encontramos um compromisso, assumido pelo autor, mencionado em algumas ocasiões, em identificar e relatar episódios constituintes da história de seu país que foram fixados por sua memória ${ }^{6}$. A geração da utopia pertence a esse repertório artístico cujo enredo está marcado de forma contundente por esses anos que se encerram na memória angolana como os anos de luta. No entanto, no que tange as intenções críticas desse romance, pondera Pepetela: "Esse romance não é uma resposta a nada. Apenas uma estória sobre uma geração que fez a independência de Angola e não soube fazer mais" (CHAVES, 2009, p. 42).

Considerando seu compromisso com a história nas linhas fundantes desse seu trabalho literário, parece-nos importante avaliar o locus enunciativo ao qual a obra está circunscrita. Quem é a voz que narra? Qual é a perspectiva desse ato narrativo?

Para pensarmos o foco narrativo presente em A geração da utopia, faz-se necessário que conheçamos de antemão alguns aspectos de sua estrutura que permearão nossa leitura. Em linhas bem gerais, o romance é realizado através da narrativa onisciente em terceira pessoa, mas há que se apontar algumas especificações no que concerne a essa classificação tão abrangente. Embora sua elaboração esteja cunhada por uma onisciência seletiva, é importante destacarmos o caráter não unitário que paira sobre ela. O narrador elege a personagem da qual irá se aproximar ao longo dos capítulos, possibilitando, dessa maneira, uma variedade de pontos de vista. Essa variação é verificável não apenas na distribuição dos capítulos como também na composição dos mesmos, mas está adstrita a três personagens principais do enredo: Sara, Vítor, Malongo; e a personagem que podemos identificar como protagonista: Aníbal.

Ainda que seja comum a seleção de mais de uma "mente" dentro de um mesmo capítulo, é notável a alternância da "mente" privilegiada em cada um deles, resultando numa perceptível polifonia narrativa. Portanto, o primeiro capítulo é narrado com a forte influência de Sara (embora ele também contenha um momento da voz de Vítor e outro

\footnotetext{
${ }^{6}$ Em entrevista para Carlos Serrano, diz o autor: "Outro objetivo é que daqui a uns tempos não haverá pessoas que tenham vivido a situação colonial por "dentro". E toda a nova geração deverá ouvir falar, apenas. Há de haver textos de história sobre o que era o colonialismo, o que era a mentalidade do colono, etc., mas forçosamente texto de história, é uma coisa fria... e as pessoas acabam por imaginar o que seria, mas não compreender profundamente, e aí é o papel do romance, fundamental, para a nova geração conseguir "viver" um pouco o que era a vida antes. Aí há também uma preocupação de registrar para a história". SERRANO, Carlos. O romance como documento. Via Atlântica, São Paulo, n. 3, dez. 1999.
} 
de Malongo); o segundo acompanha Vítor; o terceiro, Aníbal; e no quarto e último, destaca-se a presença de Malongo. A realização dessa polifonia capitular ecoa diferentes perspectivas (ainda que estejam sempre subjugadas à posição do narrador); cujo efeito conflui para uma melhor ambientação dos fatos narrados, numa tomada que separa a utopia latente da desilusão, identificáveis em momentos distintos da obra, ainda que todo o enredo pareça apontar para os caminhos que separam uma e outra.

Sendo assim, podemos notar que a utopia evocada pela crença na coletividade do primeiro capítulo, construída principalmente através do olhar de Sara, oferece lugar à angústia que contorna todo o segundo, pela voz hesitante e individualista de um Vítor (ali, Mundial) em transformação; que gera a aflição e a imobilidade evocadas pela presença fundamental de um Aníbal isolado no terceiro, abrindo espaço para a frustração e ausência de expectativa que permeia a perspectiva anticoletiva do Malongo empreendedor, expressa nas páginas que findam a narrativa. Há, entretanto, epílogos que tecem uma ligação entre os capítulos, cujo intervalo narrativo é de cerca de uma década (1961, 1972, 1982, 1991), através, principalmente, de sumários.

Torna-se imprescindível ressaltarmos que o ponto de vista do narrador, apesar da variação de perspectiva possibilitada por certa dimensão polifônica que procura estabelecer, não é variável, e coincide, principalmente, como pretendemos mostrar nesta análise, com a perspectiva do herói e do autor implícito. Ou seja, embora esse narrador acompanhe diversos personagens, ele compactua com o ponto de vista dessas duas entidades narrativas que figuram na obra a representação do intelectual engajado militante do MPLA. O que resulta, acreditamos, num ato narrativo ideologicamente marcado, no qual tais valores reverberam.

Se cada um dos capítulos compõe uma unidade no romance por estarem circunscritos a determinado locus espaço-temporal, parece-nos prudente dividir a análise em quatro partes que considerarão a experiência de leitura proporcionada pelos diálogos que se estabelecem nessas estruturas ${ }^{7}$. Ao final, observaremos o romance de forma mais panorâmica, considerando as particularidades apontadas, na tentativa de emitir opinião acerca da voz que conta essa história.

\footnotetext{
7 "Em qualquer experiência de leitura, há um diálogo implícito entre autor, narrador, as outras personagens e o leitor.” (BOOTH, 1980, p. 171).
} 


\title{
2.1 A utopia latente - a aproximação de Sara (Nascimento do projeto e construção utópica)
}

\section{A Casa (1961)}

\author{
"Portanto, só os ciclos eram eternos". (PEPETELA, 2013, p. 9).
}

A frase inaugural do romance, apontada acima, assinala, desde seu início, a força motriz dessa parte da narrativa: a ruptura com os ciclos que se pretendiam eternos, representados pela ideologia que referendava a situação colonial. No entanto, a viabilidade dessa ruptura depende, a princípio, do processo de "desalienação" dos agentes históricos. Tem-se que só a obtenção e fortalecimento de consciência política incitaria o movimento à luta anticolonial. A narrativa é construída, nesse capítulo, a partir desse pressuposto, e toda sua estrutura demonstra-se fundada no intuito de representar o cenário ideal que possibilitaria o embate entre uma antiga e uma nova ordem. Podemos observar, ao longo de nossa leitura, que esse cenário ideal será sustentado por três movimentos principais: o processo de aguçada conscientização política; o surgimento do espectro de coletividade; e a presença incontestável do sentimento utópico; todos constituídos conjuntamente irão emoldurar a consciência nacional que aqui surge. Nesse contexto, podemos ainda observar um movimento de ascensão da postura contra ideológica na voz do narrador, conforme pretendemos aqui apresentar.

O narrador, amparado pelo autor implícito, tem sua voz respaldada especialmente pela intensa aproximação que estabelece com Sara, que é a principal responsável pela ambientação do capítulo. No entanto, vale salientar que outras vozes se evidenciam, ainda que brevemente, caso de Malongo e Vítor. E parece-nos que essa evidência tem como função principal iluminar o caráter dessas personagens, através de um olhar alicerçado ainda por Sara.

Conforme anuncia o título, os episódios a serem relatados nesse momento estão situados em um locus espaço-temporal definido, que remete à história, qual seja a Casa 
dos Estudantes do Império, no ano de 1961. Situada em Lisboa, a $\mathrm{CEI}^{8}$, como era conhecida, reunia jovens estudantes africanos provenientes dos diversos países mantidos como colônias portuguesas a época em que residiam em Portugal. O encontro e as trocas possibilitadas nesse espaço resultaram, na contramão do intuito português, em uma efervescência política e cultural que contribuiu para o fortalecimento do processo de conscientização político-social dos jovens que frequentavam a casa.

Quanto ao ano que cinge o enredo podemos destaca-lo na história de libertação angolana por ser o ano de eclosão da guerra anticolonial. Dois principais eventos são significativos para esse processo: o 4 de fevereiro ${ }^{9}$, quando há um resgate de presos políticos nas prisões de Luanda e o 15 de $\operatorname{março~}^{10}$, em que ocorre a revolta do Norte. Ambos os episódios são apontados a partir do fluxo de consciência de Sara e ambientam o clima que rege essa parte da narrativa. Através de suas colocações, temos contato com as dúvidas que pairam acerca dos ocorridos nos jovens sitiados na metrópole:

As notícias enchiam as páginas de jornais, mas as informações eram poucas. A censura estava a trabalhar a triplo vapor, as tesouras nunca funcionaram tanto como agora. Os jornais enchiam-se de discursos patrioteiros, Portugal é uno e indivisível, de declarações de apoio ao regime, mas pouco de concreto sobre os acontecimentos. Sabia-se que o Norte se tinha revoltado em nome duma antes desconhecida UPA e de Lumumba, que era uma esperança no futuro. Tudo começou no 15 de março. Não, antes, em 4 de fevereiro, houve ataque às prisões de Luanda para libertar os presos políticos. Seguiu-se uma repressão terrível em Luanda, falava-se de milhares de mortos entre os

\footnotetext{
${ }^{8}$ Criada em 1944 em Lisboa, foi fechada em 1965. "É interessante registrar que a Casa dos Estudantes do Império constituiu-se num paradoxo da política salazarista. Tendo sido uma tentativa do governo português de controlar os estudantes africanos, acabou por converter-se em espaço privilegiado de ampliação do esforço para divulgar a valorização e o regate das culturas que remetiam ao continente africano." (ARAÚJO, 2005, p. 37).

9 "Em Luanda, na madrugada de 4 de fevereiro, grupos de homens, armados de catanas, com apenas uma arma de fogo, vestidos de roupa escura, atacam a esquadra da Polícia de Segurança Pública (PSP), a cadeia de São Paulo e a Casa de Reclusão, numa ousada tentativa de regatar os presos políticos detidos nas ações policiais de 1959 e 1960." (BITTECOURT, 2008: 78). Bittencourt afirma ainda que, embora essa ação tenha autoria reivindicada pelo MPLA, ela é resultado do movimento de vários grupos insatisfeito com a situação colonial. Muitos homens libertos nessa ação foram para a UPA (União das Populações de Angola).

10 "Os levantamentos que abalaram todo o Norte da Colônia em Março de 1961 e que ficariam conhecidos pela data de 15 de março possuem características muito especiais e bem diferentes do que até agora foi retratado. Claramente, foi a UPA, sob liderança de Holden Roberto, que esteve por trás de toda a preparação dos ataques às fazendas e postos administrativos portugueses. Marcada pela violência, num grau até então inédito na luta anticolonial, a revolta, levada adiante na sua grande maioria por camponeses do Norte, os Bakongo - principal base de apoio da UPA (...) insatisfeita com a exploração de café na região - acabaria por avançar sobre as áreas Kimbundu, que no frágil esquema frequentemente repetido de sobreposição e associação entre filiações étnicas e políticas corresponderia a uma zona de apoio ao MPLA. Além dos brancos, também foram vítimas assimilados, negros e mestiços e muitos Ovimbundu vindos do Sul para trabalhar como contratados na região (...).” (BITTENCOURT, 2008: 86).
} 
nacionalistas. Aí também mistério, quem executara as ações, qual o seu objetivo? Depois foi março no Norte. Um levantamento contra os brancos, os fazendeiros de café eram mortos e as povoações saqueadas. Era pelo menos essa a propaganda do governo. (PEPETELA, 2013, p. 14).

Imersos nesse locus, assim anunciado pela onisciência do narrador através, principalmente, do fluxo de consciência de Sara, tomamos contato com as principais personagens que habitam o romance: Sara, a esforçada estudante de medicina, Aníbal, o intelectual engajado; Vítor, o displicente estudante de veterinária e Malongo, o atlético jogador de futebol.

No entanto, ainda que seja assim ambientado o contexto histórico, é importante frisarmos que a presença do autor implícito que rouba a voz narrativa logo no segundo parágrafo já instituía, desde então, o espaço crítico no qual está pautado o foco narrativo.

(Na prova oral de Aptidão à Faculdade de Letras, em Lisboa, o examinador fez uma pergunta ao futuro escritor. Este respondeu hesitantemente, iniciando com um portanto. De onde é o senhor?, perguntou o professor, ao que o escritor respondeu de Angola. Logo vi que não sabia falar português; então desconhece que a palavra portanto só se utiliza como conclusão dum raciocínio? Assim mesmo, para pôr o examinado à vontade. Daí a raiva do autor que jurou um dia havia de escrever um livro iniciando por essa palavra. Promessa cumprida. E depois deste parêntesis, revelador de saudável rancor de trinta anos, esconde-se definitiva e prudentemente $\mathrm{o}$ autor.) (PEPETELA, 2013, p. 9).

Com essa aparição entre parênteses, o autor implícito emerge na narrativa com autonomia, recorrendo ao comentário, que tende a aproximá-lo do leitor. Esse recurso incita ainda uma impressão de realidade: ao relatar um episódio que ultrapassa a capacidade de onisciência do narrador, o autor formula nessas linhas uma tentativa de exceder os limites ficcionais. A indignação resultante do processo de humilhação aferido pelo outro desponta como leitmotiv da produção literária. Abaliza, dessa forma, dois aspectos preponderantes nesse momento narrativo - o universo que nele subjaz é aquele em que imperavam os valores impostos pela ideologia colonial; nascem, no seio dessa ideologia, as vozes dissidentes que procurarão subverter a ordem vigente, através de um movimento contra ideológico, cujo principal representante será o próprio narrador. 
Apoiando-se na transgressão necessária para sobressair-se a essa imposição - do outro - tão limitante, o romance é iniciado pela negativa. Ao iniciar o romance, instância significativa da manifestação da língua, com o portanto ${ }^{11}$ outrora questionado, o autor apropria-se do português e imprime sua singularidade, debochando da autoridade impressa pelo professor. Nega o colonizador e projeta a obra para o mesmo horizonte da sua atitude.

É notável aqui, no entanto, que a aspiração que conduz esse autor manifesto resplandece de sua intelectualidade. E ainda que afirme que se esconderá prudentemente, esse seu movimento nos remete para a composição narrativa que se desencadeia a partir daqui. Se o autor contesta a partir da subversão ${ }^{12}$ da língua, o narrador se apresenta para satisfazer e comungar a necessidade de libertarem-se, ambos, dos valores portugueses e o contexto aqui formulado contribui para a exaltação da conscientização necessária. E é nesse sentido que Sara se apresenta como melhor meio de emersão da aspiração que contagia a primeira parte do enredo.

Benguelense, filha de ricos comerciantes portugueses radicados em Angola e estudante de medicina, Sara assiste nascer sua consciência política com relação a situação de Angola a partir de Lisboa, através, principalmente, da observação das contrastantes diferenças entre colônia e metrópole. Ao observar as diferenças entre si e os portugueses, Sara identifica-se como angolana, instaurando assim sua impressão de nacionalidade. O que faz emergir sua indumentária libertária instrumentalizada pelo desejo de uma profunda modificação político-social de sua terra natal:

E ali, no centro mesmo do império, Sara descobria a sua diferença cultural em relação aos portugueses. Foi um caminho longo e perturbante. Chegou à conclusão de que o batuque ouvido na infância apontava outro rumo, não o do fado português. Que a desejada medicina para todos não se enquadrava com a estrutura colonial, em que uns tinham acesso a tudo e outros nada. Que o índice tremendo de mortalidade infantil existente nas colônias, se não reflexo direto e imediato duma política criminosa, encontrava nela uma agravante e servia aos seus objetivos. E demonstrou essas ideias numa palestra que fez com um médico cabo-verdiano, no ano passado. Palestra prudente com cuidadosa escolha das palavras, que lhe valeu muitos

\footnotetext{
11 "Ao iniciar a frase com a palavra "portanto" - um traço do falar angolano - o aluno é acidamente repreendido pelo professor em sua arrogância, humilha-o associando a peculiaridade de seu uso da língua a ignorância de quem vem das colônias. Desse modo, a singularidade que poderia ser entendida como um traço de identidade converte-se em "deficiência", prova, portanto, de inferioridade." (CHAVES, 2005, p. 97).

${ }^{12} \mathrm{O}$ uso do termo subversão aqui se restringe à colocação do professor citado.
} 
aplausos no fim, mas também uma chama à PIDE, a polícia política, para advertência. (PEPETELA, 2013, p. 12).

Sim, nos primeiros tempos teria de trabalhar no hospital e depois ver como chegar nos bairros periféricos. Sem apoio do Estado, porque esse só servia os ricos. Sem apoio dos ricos, porque esses só serviam a si próprios. Não era fácil, não. Só mesmo com a independência. (PEPETELA, 2013, p. 53).

Essa impressão que se aloca em Sara é exatamente aquela apontada como necessária pelos projetos que visavam a libertação. A propulsão da revolta contra o regime colonial só seria possibilitada por uma ideia de identidade que colocaria todos os agentes desse processo em comunhão de valores e em oposição aos valores portugueses, muito embora houvesse no seio dessa identidade profundas raízes heterogêneas. Sara, portanto, corresponde a essa aspiração, e acompanhando o seu desenvolvimento na narrativa temos contato com a evolução da conscientização política desperta nos jovens angolanos.

Nesse cenário de reinvindicação e início de luta, essa aproximação entre Sara e o narrador também permite que este projete a perspectiva utópica que marcará toda a primeira parte da obra. Para tanto, as fraquezas da personagem eleita são transformadas em qualidades por certa solidariedade e cumplicidade narrativa. $\mathrm{O}$ narrador, aqui assiduamente presente com sua intromissão (palpitando acerca da realidade das personagens), como pudemos verificar na cena posta acima, condensa, através de Sara, elevado grau de otimismo e romantismo. Sara enxerga o mundo à maneira que lhe apetece, usando "truques para ver as pessoas pelo ângulo que mais as favorece", segundo Aníbal, (que classifica essa atitude como "generosa, mas pouco realista") (PEPETELA, 2013, p. 62); e calcada nessa atitude de benfazejo acaba por figurar uma tentativa de edificação do espectro de coletividade, segundo ponto essencial à luta que se desenha.

Sara, dessa maneira, torna-se uma espécie de elo da diversidade que ali coexiste, prestando-se a dialogar com ampla gama de personagens, principais e secundárias. Esses diálogos acabam por fomentar a insatisfação com o sistema vigente e a comunhão entre personagens distintas. Portanto, através das manifestações dessa personagem, que aqui se estabelece como uma espécie de duplo do narrador, são orquestradas na obra as principais atitudes necessárias para o período: conscientização política e projeção utópica. 
Isso justifica a aproximação que o autor implícito propõe ao seu narrador. Sara não tem a sapiência de Aníbal, que trataremos mais adiante. No entanto, estabelecendo com ela o seu duplo, o narrador consegue harmonizar as diferenças detectáveis no caráter de cada personagem com a possibilidade de revolução, projetando na obra o que Ernst Bloch chama de sonho diurno. O filósofo alemão Ernst Bloch, em seu "O Princípio Esperança”, escrito durante a Segunda Guerra Mundial, diferencia sonho noturno e sonho diurno. Enquanto aquele está relacionado ao estado inconsciente sob o efeito do sono e do eu censor adormecido, este está inscrito no universo do consciente, da consciência antecipadora, do eu que sonha com o futuro autêntico. Para Bloch, a utopia está presente tanto na sociedade quanto no indivíduo e é detectada na esperança não passiva. Uma esperança esclarecida ligada às possibilidades concretas, através da qual o indivíduo, carregado da "consciência-antecipadora", sonha com um futuro autêntico, para o qual sua ação, guiada pela esperança e a confiança, é fundamental. Nesse futuro, portanto, imaginado através do sonho diurno, existe a satisfação do ser dentro de uma realidade possível. Entre as diversas formas de realização do sonho diurno, Bloch indica o papel da arte na perspectiva do porvir.

O otimismo e a confiança de Sara nos agentes que a cercam encarnam as ações necessárias para o desenho do sonho diurno, mas para dilatar a consciência antecipadora o narrador opta por desmascarar os problemas do presente que são obstáculos para o futuro. Ao vincular-se a Malongo e Vítor (com menos intensidade), o narrador propõe uma avaliação sobre os problemas resultantes da colonização que deveriam ser superados. Estabelece, assim, planos distintos na narrativa: enquanto em Sara é perpetuado o caráter que ambiciona a luta (consciência e utopia), em Malongo e Vítor reverberam os obstáculos que a ela se apresentam.

Como resultante dessa equação, temos contato com os pontos fracos de Sara, que o narrador evidencia, sem, no entanto, descredibilizá-la. O erro não está nela, está no outro. Exemplo disso é a passagem em que, ao questionar o comportamento de Malongo, Sara acaba por tomar a verdade como mentira e a mentira como verdade, num princípio de boa fé que contraria a realidade do caráter do seu namorado, explicitado a partir da aproximação que o narrador estabelece com o jogador:

Sara levantou-se. Foi apagar o cigarro no cinzeiro. Procurou controlar a fúria. Estava a gozar com ela? Podia ser assim irresponsável que não 
se interessava com uma notícia tão importante? Por vezes, não sabia se ele mentia sempre ou só às vezes. A sua primeira suspeita parecia infundada, ele fora sincero, não a procurava porque andava chateado com o futebol. Mas custava a acreditar que fosse tão apolítico, numa altura daquelas. (PEPETELA, 2013, p. 44).

Ao aproximar-se de Malongo, o malanjino jogador de futebol e namorado de Sara, o narrador evidencia ao leitor a forma de pensar e agir dessa personagem, contrariando, como fica claro em diversos momentos, a visão que a namorada insiste em nutrir sobre ele. Numa expectativa de reverter o quadro apolítico do namorado, Sara parece não se aperceber de certas qualidades de Malongo, mas o narrador revela os pontos críticos de sua postura e a ineficiência da percepção da própria Sara.

A partir desse posicionamento do narrador, podemos observar o Malongo persuasivo, valendo-se de seu poder de sedução, esquivando-se de responsabilidades até mesmo quando diz respeito ao futebol. Além disso, temos contato com a perspectiva alienada do rapaz, que pensava apenas nos pequenos benefícios particulares (tornar-se jogador principal de uma equipe de futebol lisboeta), em detrimento dos malefícios enfrentados por seu país, por seus conterrâneos e por ele mesmo, consequentes do sistema colonial opressor. Se com o alicerce do olhar de Sara criamos simpatia por certa ingenuidade e leveza de espírito que transparece nas atitudes do jogador, rapidamente o narrador nos apresenta características de Malongo que despertam a desconfiança do leitor, como fica nítido na frieza com que encara a possibilidade de tirar proveito de uma situação em que se anuncia como vítima.
A situação convinha-lhe perfeitamente (...) tinha todo o tempo livre para os últimos dias de Denise. E mesmo um pretexto preparado, caso Sara ouvisse alguma coisa sobre essa ligação. Clarro, estava chateado conitgo, apareceu a francesa, preciso de me distrair. Nunca teria acontecido se não me andasse a esconder as coisas. Tinha pois que manter a posição de orgulho ferido, pelo menos até Denise ir embora. (PEPETELA, 2013, p. 77-78).

Outra personagem que recebe significativa relevância nesse capítulo é Vítor. Vítor, de Huambo, estudante pouco aplicado de veterinária e que vai descobrir em Lisboa a necessidade e a urgência da luta de independência. Há, quando acontecem as primeiras investidas da guerra que chegam aos estudantes sitiados em Lisboa, uma introdução dessa personagem à crítica político-social. Cresce sua consciência para com os problemas da terra natal à medida que diminui seu interesse com os objetivos iniciais 
que o levaram a Lisboa. A narrativa que incide sobre Vítor, no entanto, não nos leva ao questionamento de seu caráter tão evidentemente explicitado como com Malongo.

Entretanto, vale observar que em relação a Vítor parece ocorrer o início de um ritual de passagem na medida em que as suas verdadeiras impressões de que não sabia o que ia acontecendo, vão se confirmar ao longo do capítulo. O sentimento de inferioridade é sua marca registrada e o que acena para a sua potencialidade de vir a se formar como outro indivíduo, confrontado que é com aqueles que já defendem um discurso de emancipação social mais esclarecido politicamente.

Vítor se sentia intimidado. Começara a ler umas coisas, a discutir com
os mais-velhos, mas reconhecia a sua ignorância. Como argumentar
contra um tipo que passava a vida a ler e a discutir teorias de que ele
nem sequer ouvira falar? E ainda por cima sem levantar a voz,
pacientemente, como um professor ou um padre que explica algo a
uma criança. (PEPEPTELA, 2013, p. 97).

$\mathrm{O}$ que fica evidente na intimidade que se estabelece entre Vítor e a onisciência narrativa é que seu sentimento de inferioridade ecoa em diversas situações vividas por ele. A primeira é com relação a Sara, por ser ele incapaz de estudar para exames no período conturbado, enquanto ela própria prepara uma tese para defesa. A seguir, vivencia suas incapacidades intelectuais com Elias, conforme vimos na passagem supracitada. Surge por fim seu sentimento de inferioridade com relação às mulheres com as quais se envolve emocionalmente, aqui Fernanda e Esmeralda. Vítor parece estar em situação de igualdade com Malongo, mas apenas no que tange sua experiência negativa, qual seja a capacidade de ser reprovado em diversos exames. Tal colocação inferiorizada aferida pelo narrador, por vezes com contribuição da própria personagem, contribui para a formatação de seu caráter ao longo da narrativa.

Apenas uma das personagens, das quatro que se apresentam como protagonistas desse romance, não tem sua mente contemplada pela onisciência narrativa: Aníbal. Em ação nessa parte narrativa algumas vezes, Aníbal é acompanhado por um narrador que com ele se restringe a observação. Todavia, suas ações são analisadas por Sara, Malongo e Vítor, e essas considerações construídas por diferentes ângulos, somadas a narrativa de suas ações, permite que vislumbremos em Aníbal nuances do herói de guerra. Ainda que seus dotes físicos pareçam contrariar tal posição: "Baixo, magro, sempre agarrado aos livros e às ideias, não era propriamente a imagem que se fazia dum 
herói" (PEPETELA, 2013, p. 56), sua personalidade supera qualquer expectativa "Dava uma sensação de fragilidade. Porém, ela sabia, era todo o contrário, uma tremenda força interior". (PEPETELA, 2013, p. 21).

Se a posição de Sara prospecta a luta e a de Malongo e Vítor lhe criam algum obstáculo, Aníbal representa o homem ideal para a execução. Com uma consciência política já avançada, fruto de sua formação intelectual questionadora que lhe rende a alcunha de Sábio, na segunda parte do romance, o seu discurso assume oposição ao discurso colonial, como podemos observar:

Ganhara fama no meio universitário e muita gente, mesmo de outros cursos, ia assistir às suas provas orais, adivinhando polêmica. A assistência ficava raramente frustrada. Perante a sua solidez de argumentos, os professores tinham de o classificar com notas máximas, apesar das posições progressistas defendidas pelo examinando. A tese de fim de curso apareceu como uma provocação, uma análise da política colonial do século XIX, em que demonstrava que o Estado português liquidou a burguesia angolana que ganhava consciência de sua diferença e se encaminhava para posições autonomistas inspiradas nos princípios da Revolução Francesa. (PEPETELA, 2013, p. 21).

Há de se notar que a contestação de Aníbal que toma forma a partir de sua formação o coloca em posição privilegiada com relação às posições do autor implícito, por corresponder às suas atitudes. Aníbal contesta a condição colonial a partir da crítica que realiza ao Estado português com sua tese sobre como a política colonial portuguesa do século XIX liquidou a burguesia angolana. Assume, assim, a postura de contestação muito próxima a do autor implícito - evidenciando desde aqui o seu ponto de vista como o mais próximo ao da perspectiva narrativa. Essa correspondência parece justificar a sublimação do poder onisciente do narrador com ele. Ao elevar-se ao nível do autor implícito, Aníbal dispensa um narrador que lhe acompanhe os pensamentos. Sua imagem é construída a partir das atitudes e das impressões que desperta nos outros e, nesse sentido, ele aparenta ter certa autonomia em relação ao narrador, o que faz com que esteja em situação de igualdade com este. A autonomia com relação ao narrador irá evidenciar outro ponto significativo da posição do protagonista do enredo: Aníbal representará, como pretendemos aqui apresentar, outro espectro importante na estruturação narrativa - o homem ideal. E é através dele, transformado em uma espécie de espelho balizador de comportamentos (que é deformante quando em contraposição moral), que partirão as posições de afirmação ou de negação do narrador. 
Em equidade perante o autor implícito, narrador e personagem compartilham a visão de mundo, o que fica evidente pela simpatia que nutrem por Sara; as restrições a certos comportamentos de Vítor e a recusa a Malongo. E se substituirmos as personagens por aquilo que elas parecem figurar no ambiente narrativo devido às suas características, temos que compartilham a simpatia pela prospecção da luta através da conscientização política, a coletividade e a utopia, restringem o sentimento de inferioridade inculcado pela colonização, recusam a alienação, empecilho máximo para qualquer contestação.

As ações apresentadas por Aníbal, observadas em grande parte pela duplicidade narrador-Sara, o tangenciam como uma espécie de arquétipo do homem ideal para aquele momento histórico. Escamoteado o seu interior, Aníbal emerge como uma espécie de mentor intelectual de Sara, como evidenciam certas passagens:

Tinha de perguntar ao Aníbal, ele era obrigado a ser especialista dessas coisas.

Instintivamente, assimilava as reservas de Aníbal como suas. E ele, a sua bússola, ia desaparecer irremediavelmente. Tinham de ter uma conversa franca antes disso, o amigo não a podia deixar à deriva.

Decididamente, só Aníbal lhe podia apontar alguma luz. (PEPETELA, 2013, p. 10, 88, 93).

O narrador compactua dessa expectativa para com a personagem ao desvelar durante a narrativa ações que a colocam na vanguarda da revolução. Aníbal, muito antes das outras personagens, entra no mundo da clandestinidade e foge de Portugal. Sua postura dá vazão na narrativa para o início da ruptura com ciclo do colonialismo e estabelece uma detectável coerência com o projeto de emancipação angolana. Ainda algumas informações omitidas pela voz narrativa parecem ambicionar a perfeita elaboração da construção nacional, e nessa lógica não temos acesso, por exemplo, ao local de origem de Aníbal (Aníbal não é de uma região, é de Angola), embora haja insistência em localizar as de outras personagens (Vítor - Huambo, Malongo - Malanje, Sara Benguela, e assim por diante). As ações de Aníbal ainda reverberam nas observações de outros personagens, como exemplo ou contraponto. E mesmo na desconfiada portuguesa, Marta, desperta a admiração, ainda que essa seja lúcida o suficiente para antever suas desventuras:

- Se não morrer, o que se enquadra melhor com a sua maneira de ser, vai desiludir-se. A tal revolução que tem à frente não vai ser como ele 
a imagina. Nuca nenhuma é como os sonhos dos sonhadores. É um sonhador, apesar de toda a sua linguagem rigorosa de comunista. Acaba por ter ideias mais libertárias que as minhas, que ele chamava de anarquista. As revoluções são para libertar e libertam quando tem sucesso. Mas por um instante apenas. No instante seguinte se esgotam. E tornam-se cadáveres putrefatos que os ditos revolucionários carregam às costas toda a vida. (PEPETELA, 2013, p. 131).

Observando, portanto, o desenrolar do ato narrativo, temos, como se tentou apontar até aqui, o seguinte quadro: o narrador mancomunado com Sara duplica seu ato narrativo permitindo que insurjam na narrativa a ideia de consciência política, a coletividade e a utopia, que, colocadas assim ao leitor, fazem-no tomar partido, abraçando como suas as aspirações da personagem. No contraponto, aproxima-se de Vítor e Malongo para clarear acerca dos problemas que, resultantes do sistema colonial, poderiam obstruir a luta, qual seja a alienação e o sentimento de inferioridade. E ainda desenha, através do olhar de Sara e de seu próprio contar, um herói que desponta como vislumbre do homem angolano. Parece-nos, dessa maneira, que tal posicionamento vai de encontro ao projeto do MPLA com relação à situação e aos homens que deveriam compor o projeto de emancipação.

O narrador delineia o quadro e, nessa composição, surge um herói através do qual podem ser vislumbrados os ideais que permeariam a identidade angolana a ser construída, segundo o projeto do MPLA. Nesse sentido, as orientações da narrativa convergem para as ambições do Movimento. Podemos citar como parte dessa convergência o engendramento da noção de identidade, o que resulta na inadequação de qualquer exclusão racial ou étnica (e, assim, Sara que é branca passa a ser protagonista e Aníbal, como herói, não tem sua origem revelada); e a apresentação do importante papel da elite intelectual nesse processo (temos então a presença de Aníbal e do próprio autor implícito); além, obviamente, da evidente preferência pelo ideário socialista (representado por todas personagens principais que aparecem nesse quadro, exceto, vale lembrar, Malongo).

Assim colocado, criamos uma simpatia com o MPLA e cabe ressaltar que esse apego aos valores do MPLA condicionam as posições do próprio narrador, conforme veremos no desenvolvimento narrativo. E se temos que narrador, autor implícito e herói comungam uma visão de mundo, temos também que os atos aqui narrados estão marcados pela ideologia presente nas bases do projeto do MPLA. As marcas dessa 
ideologia, no entanto, insurgem nessa parte narrativa com viés positivo, embora desponte alguma contrariedade no que tange o percurso narrativo, conforme mencionamos. E o desfecho anunciado pelo epílogo coopera com essa perspectiva otimista apregoada pela comunhão narrador-Sara. Mesmo pegos na fronteira com a Espanha, o grupo consegue livrar-se, através de atuações estrangeiras, da prisão e da tortura do governo de Salazar, dirigindo-se a Paris, "a cidade da luz e da esperança" (PEPETELA, 2013, p. 139).

\subsection{A guerra desfazendo as ilusões - o narrador e Mundial}

\section{A chana (1972)}

Voltava a sentir a leveza dos tempos de glória em que nada o fazia parar, que lhe dera fama dum homem de vontade férrea junto dos companheiros. Naqueles tempos longínquos em que perseguia, imbecil que eu era, um sonho coletivo. Em que a ideologia o fazia tudo enfrentar com fé religiosa de missão. (PEPETELA, 1991, p. 179 - perspectiva de Vítor - Mundial).

No segundo capítulo da narrativa ocorre uma brusca ruptura com o clima emergente do primeiro, que será delineada principalmente pela posição do narrador e precipitará uma inversão do clima positivo que emerge do primeiro ato narrativo. No entanto, alguns elementos estruturais mantém a unidade na narrativa, embora nos projetem para as diferenças que entre eles despontam. O título mantém semelhança ao primeiro capítulo, ainda que anuncie uma ruptura de onze anos com a primeira fase narrada. $\mathrm{Na}$ similaridade do elemento estrutural, temos ainda que a voz narrativa inaugural é "roubada" e o narrador perde a voz momentaneamente. Mas se outrora a perdeu para o autor implícito que contestou e projetou a narrativa para o horizonte da superação de um ciclo (o ciclo colonial, vale lembrar), aqui o novo narrador temporário é Sábio que, através de uma página perdida de seu diário, anuncia alguma má disposição e descrença ao equalizar o otimista e o pessimista, rompendo assim com a utopia desenhada momentos antes.

Quando retoma a voz, percebemos que o narrador assume agora a posição de narrador-observador, numa ruptura momentânea com a onisciência. E dada a expectativa criada pela presença da página do caderno de Aníbal, somos levados a 
pensar que se trata de ações dele. O homem está perdido na mata e a ideia de labirinto que irá percorrer toda essa parte do enredo, como bem anuncia seu início, é respaldada principalmente pela narração não linear, proporcionada por digressões, o que colabora para a percepção da ruptura entre os dois capítulos, uma vez que o primeiro tinha a linearidade como característica, além de contar com poucas digressões temporais (o que vincula a narrativa ao tempo presente de maneira mais contundente). Entretanto, as digressões presentes aqui terão como função a separação entre o passado (narrado lá) e o presente (realizado aqui), como veremos mais a frente.

O distanciamento do narrador, que se furta teporariamente ao comentário através da perda, também temporária, de onisciência, resulta numa explícita mudança de ambientação, que culmina em nosso afastamento do fato narrado. No primeiro capítulo, Sara inicia a narrativa nos aproximando da história, situando-nos no locus espaçotemporal; estávamos na zona urbana, e ainda que o território não fosse angolano, o ambiente por ela desenhado era acolhedor uma vez que nele resplandeciam os novos sonhos relacionados à Angola. Aqui, no entanto, somos projetados para um cenário pouco acolhedor, de uma natureza que repele o homem, muito mais do que o acolhe, ocasionando um estranhamento entre espaço, personagem e leitor.

Assim como a mudança repentina de espaço e de postura narrativa, ocorre, cooperando com tal distanciamento, a percepção de que o projeto que ascendia anteriormente, qual seja a libertação de Angola através de uma luta que propiciasse a sua população uma maior equidade social, encontra-se longínquo, ainda que a guerra esteja presente. O homem perdido na mata, cuja identidade é omitida nas primeiras páginas do capítulo, tem ações apresentadas pelo narrador-observador que apontam também para ruptura com a projeção utópica proporcionada por Sara, uma vez que vai se definindo como o anti-espectro de coletividade, ao se afugentar do povo.

Para não ser retardado, recusava a companhia dos elementos do povo que ao grupo pediam para integrar e montava acampamento afastado das fogueiras de mulheres, velhos, crianças, que recuavam para a fronteira, fugindo da guerra.

E anuncia um cenário degradante:

Os velhos e os homens e as mulheres, um pano esfiado nos quadris, transportavam às costas bolas de cera e quindas com restos de fubá. Os homens ainda possuíam um machadinho, com o qual apanhavam o 
mel na mata. As mulheres levavam as cada vez mais inúteis panelas. A cera era o seu único bem, o capital que iriam vender ao primeiro comerciante da fronteira para resistirem aos meses de fome. As ofensivas inimigas tinham despovoado os kimbos. Os helicópteros despejavam bombas metralhadoras e homens treinados para matar. (...) Quando avistava o grupo de guerrilheiros, o povo vinha pedir, deixem-nos ir convosco, precisamos da proteção das vossas armas. Ele não respondia. Mandava o grupo avançar mais depressa. (PEPETELA, 2013, p. 146-147).

Quando o narrador volta a ter onisciência, revela o fluxo de consciência do homem que via o povo como peso inútil no meio da guerra e da miséria, não sentia remorsos e deixava de se pensar como intelectual. E se alguma dúvida paira sobre nós de que poderia se tratar de Aníbal, demonstrando assim uma mudança repentina de caráter dessa personagem, logo temos prova do contrário: "A contragosto, teve que reconhecer que Sábio era o mais prudente dos dois" (PEPETELA, 2013: 149). Anunciada assim a oposição entre o sujeito que procura manter a distância do povo e o Aníbal guerrilheiro, sobrepõe-se, através da onisciência narrativa, a superioridade deste: "dava cada vez mais raivosamente razão ao Sábio que mesmo ali o humilhava.” (PEPETELA, 2013: 150).

Antes de anunciar que o sujeito da narrativa agora é Vítor, aqui Mundial, temos contato com as posições de Sábio. Embora o narrador acompanhe aqui de perto os movimentos de Mundial perdido na mata, vivenciando a dúvida entre se entregar ou não ao inimigo, Sábio se apresenta como seu contraponto e no seu fluxo de consciência acionado por sua memória, projeta luz sobre o seu próprio comportamento. O sentimento de inferioridade detectável em Vítor anteriormente, como apontamos, aqui toma nova dimensão, manifestando-se especialmente quando comparada a sua personalidade à de Aníbal. E aqui se dá pela primeira vez na narrativa o processo deformante do Aníbal (Sábio) enquanto balizador dos atos. Ainda que o foco narrativo se junte a Vítor, ele, como Mundial, projeta-se em Sábio todo o tempo, e em tal projeção podemos ver suas deformidades, uma vez que Mundial passa apresentar os valores opostos aqueles que resplandeceram no primeiro capítulo e, consequentemente, aos valores do próprio Sábio.

Perdido na mata, a aproximação entre narrador e Vítor impõe a estrutura narrativa um viés labiríntico insinuado por digressões através do fluxo de consciência de Mundial. Tais digressões remetem, na maior parte do tempo, a como Vítor 
transformando-se definitivamente em Mundial, reage ao ainda forte caráter de Sábio. Uma vez quebrado o clima da narrativa pela ausência da perspectiva romântica de Sara, rompido o tempo narrativo por uma lógica agora não linear, com um narrador que varia entre a onisciência e a observação, o que se mantém como unidade, além dos dois elementos supracitados, é a postura de Aníbal.

Dá-se então que se encontram em contraposição dois posicionamentos perante a luta, que tomam forma mais explícitas nas grandes discussões travadas entre os dois, reveladas pela memória de Vítor. Dessa contraposição, o narrador toma partido, ao estabelecer com Vítor, ainda que esse seja agora o seu duplo narrativo, uma relação de distanciamento. Ao contrário de sua postura solidária e cúmplice com Sara no primeiro capítulo, aqui o narrador estabelece uma permissão narrativa para o discurso indireto livre, alimentado pelo fluxo de consciência, características já presentes outrora, mas com um narrador não solidário, cujo afastamento, incialmente proposto pela sua posição de observador de um sujeito sem identidade, não será superado.

Mesmo ao ser reestabelecida a onisciência narrativa, o distanciamento se mantém através de certa evocação irônica, caso, por exemplo, da passagem em que o narrador revela o pensamento da personagem "A imagem que fez de si próprio dá-lhe ânimo". (PEPETELA, 2013: 163), ainda que todo o percurso narrativo anterior a esse demonstrasse o pânico para com a situação na qual se encontrava. A ironia, ensaiada aqui e mais fortalecida no último capítulo, aponta para o que podemos observar como negatividade narrativa. A partir dela, o narrador nega as personagens com as quais não compartilha a ideologia.

O tribalismo manifestado aqui principalmente na voz de Vítor imputa à narrativa a lacuna entre a palavra de ordem outorgada no primeiro capítulo e a ordem estabelecida neste segundo, desfazendo finalmente o espectro de coletividade que Sara fez emergir anteriormente. $\mathrm{O}$ movimento em direção à unidade na identidade que, ainda que com alguns problemas apontados, prevalece lá principalmente pela presença de Sara é substituído aqui pelo isolamento de Vítor e sua visão acerca das diferenças presentes no Movimento. Sara, por sua vez, não só sai do centro narrativo como acaba por desaparecer da narrativa, sendo citada apenas para que saibamos o quão distante ela ficou da guerra que se estabeleceu, tanto ideológica quanto materialmente. 
Lembrou da Sara e disse pra lhe escrever. Meteria a carta no correio, na fronteira. Ela continuava em Paris e esperava por notícias, qualquer bilhete era um lenitivo para dez ou onze anos de exílio. E que lhe vou dizer, que espere e creia, um dia será chamada, como os justos que esperam a graça de Deus? Não, Mundial, deixei de prometer o Paraíso há muito tempo, quando dele perdi o rasto. Não sei mentir. Deixa-a pensar que isto aqui é uma maravilha, que nos batemos heroica e generosamente pelo futuro da terra. A verdade irá destruí-la. (PEPETELA, 2013, p. 184). ${ }^{13}$

Portanto, o que se destaca nesse momento narrativo é o enorme contraste entre o clima a princípio enunciado pelo capítulo que inaugura a narrativa e esse que se coloca a partir daqui: o enorme contraste entre o projeto anunciado e o que se consolida, podendo o segundo destruir o primeiro, segundo as palavras acima de Sábio. Nesse sentido, há um movimento narrativo, possibilitado pelo fluxo de consciência de Vítor, que expõe as fissuras do projeto:

Maldita guerra! Os que a iniciaram abandonaram-na os outros que se arranjem... Caramba, estou a dizer o mesmo que o povo. Mas é verdade, merda. Ninguém o tinha obrigado, se nela participava era por sua vontade. Deixa lá disso, sei bem como é isto de ser voluntário: uma pessoa é obrigada, o que dirão os amigos, o que será do futuro? Voluntariado forçado! A esta obrigação chamamos de consciência política, nome bonito para nos enganarmos. Nuns é para enganarem, são os idealistas. Noutros, é para engarem os outros; são os vivaços. (PEPETELA, 2013, p. 164).

Através da aproximação de Vítor da voz narrativa temos contato com a enorme dicotomia que se faz durante a guerra entre aqueles que ainda lutavam pelo projeto inicial e esses que já se predispunham a pensar nas ambições pessoais. $\mathrm{O}$ autor implícito aproxima seu narrador de Mundial, deixando-o, aparentemente, à deriva. Se lá contribuíam para sua consolidação a voz de Sara com a visão de Aníbal, aqui ele se desprende do duplo que o acompanha e anuncia um viés irônico, mas que não consegue se estabelecer de maneira contundente. Muito embora, ainda que haja certo enfraquecimento da voz crítica do narrador, tão elevada no primeiro capítulo, aqui ele se mantém sob as égides do autor implícito e alicerçado por Aníbal, com a diferença de seu duplo que se desloca de Sara (com sua utopia) para Vítor (com seu complexo de inferioridade).

Vítor escapa de se entregar ao exército português após um longo período em que estava perdido e encontra abrigo num grupo de guerrilheiros que o acolhe. Perante esse

\footnotetext{
${ }^{13}$ Diálogo entre Sábio e Mundial.
} 
grupo, assume parcialmente a posição de herói e, no entanto, sua postura "tribalista" desperta desconfiança de Mukindo, com quem trava discussões que acabam por apresenta-lo no completo e definitivo oposto de Aníbal. Do labirinto emocional de Vítor (que em delírio chega a confundir as suas memórias com as de Sábio - no processo de espelhamento deformante - como podemos notar na passagem que menciona Mussole $^{14}$ ), toma corpo o labirinto temporal imposto pelas digressões, e são esses fatores que parecem colaborar contundentemente para que uma postura narrativa que se estabelece entre a observação e a ironia, mas que, no entanto, não consegue manter o leitor vinculado ao projeto inicialmente enunciado, transformando assim o otimismo em pessimismo.

As diversas rupturas aqui apontadas se equacionam e determinam a maior e mais importante de todas: a ruptura entre o passado e o presente. E no ápice dessa ruptura há o rompimento definitivo entre Mundial e Sábio, na simbólica morte do Mbambi:

Não, nada já tinha importância. O passado fora enterrado na areia da chana e mesmo as promessas e os ideais coletivos. O que importava agora era o que iria encontrar na penugem azulada do futuro, o seu futuro. Ele, Mundial, já estava a salvo, já tinha um futuro. E o Sábio? (PEPETELA, 2013, p. 224).

Nesse contexto, em que Sábio representa o passado e Mundial o presente, o capítulo é finalizado com o epílogo que anuncia a morte de Sábio em combate e que parece anunciar certo arrependimento na postura de Mundial. Na guerra, as coisas não foram bem e no árduo combate da Frente Leste, com a desestrutura ocasionada pela falta de dinheiro ou de interesse dos grupos que chefiavam o Movimento, esmorecem os sentidos da luta. O inimigo colonial ocupa, na maior parte do enunciado, apenas os delírios de perseguição de Vítor perdido na mata. Na ausência desse inimigo, outras questões tangenciam o capítulo, anunciando a desforra dos princípios que norteavam o início da narrativa através do posicionamento de Mundial.

\footnotetext{
14 “O cansaço finalmente se torna agradável, pois não o deixa sentir frio e mergulha-o num torpor próximo do delírio. As imagens passam pelo cérebro como se tivesse presenciado o que nunca vira. Mas o Sábio contara as coisas com tal sentimento e colorido que ele via Mussole, o seu corpo flexível dançando para ele, o corpo despedaçado sangrando para ele, os olhos do Sábio sobre ela reclinado derramando lágrimas dele. Sim, fora ele que amara Mussole, fora ele que se extasiara nas suas carícias, fora ele que com ela morrera naquele dia de abril do ano passado em que as chanas cantavam de florzinhas coloridas e os rios se penteavam de grandes folhas redondas. (...) E queria agora o Sábio usurpar-lhe o direito a chorar Mussole? Mussole era sua, sua era a saudade dela como o fora o seu corpo, como o fora a renúncia da sua perda. Mussole, Mussole, Marilu... Fernanda.” (PEPETELA, 2013, p. 167-168).
} 
A hesitação da voz narrativa em se assumir irônica revela uma crítica ainda não muito centrada em sua negatividade, embora já não possa ser traspassada pelo otimismo anterior. O narrador, que no capítulo anterior aparecia com frequência entre os diálogos e subordinava-se a algumas personagens para plantar sua perspectiva crítica através da multiplicidade de perspectiva, aqui se fixa em Vítor e é suplantado por seu monólogo interior. A ironia se ensaia na voz narrativa, mas é atenuada pela perspectiva pessimista do personagem perdido na guerra. Diante dessa premissa, fecha-se o capítulo sem certezas. Embora tenhamos apontamentos que levem a desconfiança quanto ao caráter de Vítor (por suas lembranças que disponibilizam a leitura de seus posicionamentos "moralmente fracos", tal qual lhe afirma Aníbal), ainda assim a possibilidade de seu arrependimento exposta no epílogo nos leva a dúvida. Há sem dúvida o rompimento entre o passado e o presente, mas o final do capítulo aponta, ainda que sem o otimismo do primeiro capítulo, para uma retomada incerta com relação ao futuro de Vítor, que ao saber da morte de Sábio, parece demonstrar certo arrependimento.

\subsection{O último refúgio - foco narrativo em Aníbal}

\section{O polvo (Abril de 1982)}

O capítulo que se segue também tem seu início com um narrador-observador e, aos moldes do capítulo anterior, apresenta uma cena ligando homem à natureza. No entanto, podemos dizer que aqui as diretrizes se dão ao revés. Se em A Chana o primeiro momento narrativo contempla um homem em completo desencontro com os meios naturais que o cercam, entre a guerra e a hostilidade de um ambiente que o repele, aqui assistimos, através da voz narrativa enunciada pelo narrador em terceira pessoa, o entrosamento entre o homem e o meio ao qual parece pertencer.

Se outrora a tangibilidade desse entrosamento parecia impossível, uma vez que Mundial se debatia entre os perigos da floresta e da chana e o desafio de estar sozinho, perdido, em meio à guerra e aos seus próprios ideais, aqui temos, a princípio (e não saberemos de antemão de quem se trata) a situação oposta de um homem que entra na 
água para caçar um peixe. Caçar e não pescar ${ }^{15}$, ato que anuncia um contato direto com a natureza, arrematando o que lhe é para a sobrevivência sem propagar qualquer tipo de destruição maior. Temos, portanto, o grande contraste entre a atmosfera hostil fixada no capítulo anterior, do início ao fim, e a atmosfera pacífica propiciada pelo entrosamento homem-natureza presente no início deste capítulo.

Também aos moldes do segundo capítulo, aqui não temos conhecimento de imediato sobre quem seria esse homem. E se lá somos levados a imaginar que Aníbal poderia ter sofrido uma brusca transformação de caráter, aqui, pelo contrário, somos levados durante as primeiras páginas a achar que Vítor teve uma modificação "moral" desde a morte de Aníbal (anunciada no epílogo anterior). Essa estrutura, realizada e repetida, permite que o narrador brinque com a expectativa do leitor, através da perspectiva da incerteza, em tempos tão incertos.

O relato do narrador-observador apresenta, no entanto, uma quebra com relação ao início da narrativa o capítulo anterior: o ritmo. Temos que no início de A Chana, mesmo quando apenas o narrador se manifesta, sem o fluxo de consciência de Vítor, o ritmo é frenético e provoca incômodo. No intenso contraste com o primeiro capítulo, ali, no segundo, esse ritmo causa uma espécie de ruptura narrativa que nos remete para uma nova forma que vai se desenhar ao longo do capítulo. A mesma ruptura acontece aqui, dessa vez passamos do frenesi à calmaria, pautada principalmente pela ação da personagem e pela voz preponderante do narrador, que ainda quando misturada ao fluxo de consciência da personagem que desconhecemos, configura-se de maneira plácida, como podemos notar nos trechos abaixo:

\footnotetext{
Entrou na água, com um arrepio no corpo magro. Foi nadando, só a bater os pés, olhando para o fundo e respirando pelo tubo. Dirigiu-se para a esquerda, onde havia os fundos rochosos, com mil e uma pequenas cavernas onde repousavam os peixes. (...) Ele observava o seu mundo marinho sem se apressar. (...) Os cardumes fugiam à sua frente, mas o homem não se preocupava. Sabia ia encontrar o peixe pretendido na muralha dos recifes. Escolhia antecipadamente. Hoje apetece-me um pargo, uma grande pargo vermelho, churrascado nas brasas. Por vezes acontecia não encontrar a refeição desejada e ter de se contentar com outra. Mas era raro. Tinha toda a manhã para

15 "O pescador fica fora do meio do peie, ou numa praia ou num barco. Invade o meio do peixe com uma arma, rede ou anzol, apenas a arma entra nesse meio. O caçador penetra no meio marítimo, arrisca o corpo a corpo, usa a arma contra um adversário-vítima determinado que vê e respeita. Os dois matam, mas o pescador mata sem sequer pensar nisso." Conversa entre Sábio e Ximbulo. (PEPETELA, 2013, p. 233-234).
} 
procurar. Era dono do seu tempo, a única liberdade válida. Afastou-se deliberadamente do extremo sul, onde estava a gruta. Nem queria pensar nisso, bastavam os pesadelos noturnos de toda a vida. (PEPETELA, 2013, p. 230-231).

A certeza de se tratar de Aníbal só virá algumas páginas depois do início dessa parte narrativa. Na casa da ilha da Caotinha, baía próxima à cidade de Benguela, sul de Angola, Aníbal convive com poucos vizinhos: a família de Ximbulo, e sustenta um contato com a mangueira, plantada por ele em seu quintal e na qual, para ele, dorme o espírito de Mussole. A imagem que se tem de si na cidade é de um maluco. Suas ações, no entanto, apontam para um extremo senso crítico pautado pela lucidez e frustração para com os caminhos adjacentes da independência angolana. Mundial se torna ministro, Malongo mantém-se afastado. E Sara retorna a narrativa para resgatar o protagonista, através do enlace amoroso que finalmente se materializa entre eles.

Nesse capítulo, imergimos então, através do fluxo de consciência de Aníbal e da narrativa em terceira pessoa, no sentimento de frustração para com o projeto que vingou apenas em parte. Numa Angola independente, agora sob a violência de uma guerra civil que não conta mais com o inimigo comum: o colonizador, Aníbal se isola, afastando-se e contradizendo com suas ações a realidade de fora da baía. Se isolado em seu mundo, ele tem uma vida de subsistência, pautada pelas mínimas necessidades, lá fora o que impera é a corrupção e a ambição daqueles que ocuparam o poder.

A partir de seu encontro com Sara, temos contato com uma narrativa que se desenvolve através, principalmente, de diálogos ou monólogos da personagem central do capítulo - o próprio Aníbal. O narrador empresta sua voz na maior parte do tempo para um Aníbal que discorre sobre a frustrante realidade de uma geração denominada por ele de geração da utopia, decretando a si mesmo como morto e desencantado:

- Enganou-se numa coisa, colocou a questão numa alternativa. Eu morri e desencantei-me. Os dois caminhos num só. (...)

- Isso de utopia é verdade. Costumo pensar que a nossa geração se devia chamar a geração da utopia. Tu, eu, o Laurindo, o Vítor antes para só falar dos que conheceste. Mas tanto outros, vindos antes ou depois, todos nós a um momento dado éramos puros e queríamos fazer uma coisa diferente. Pensávamos que íamos construir uma sociedade justa, sem diferenças, sem privilégios, sem perseguições, uma comunidade de interesse e pensamentos o paraíso dos cristãos, em suma A um momento dado, mesmo que muito breve nalguns casos, fomos puros, desinteressados, só pensando no povo e lutando por ele. E depois... tudo se adulterou, tudo apodreceu, muito antes de se chegar 
ao poder. Quando as pessoas se aperceberam que mais cedo ou mais tarde era inevitável chegarem ao poder. Cada um começou a preparar as bases de lançamento para esse poder, a defender posições particulares, egoístas. A utopia morreu. E hoje cheira mal, como qualquer corpo em putrefação. Dela só resta um discurso vazio. (PEPETELA, 2013, p. 245-246).

Temos aqui que no universo da voz narrativa, a voz do narrador se apaga, como já havia ocorrido, parcialmente, no capítulo anterior, dessa vez obstruído pela voz preponderante de um herói frustrado e desiludido com os rumos do país no pósindependência. Para o narrador, restam apenas alguns momentos de uma narração em terceira pessoa realizada apenas para pontuar as cenas que precisam de apresentação, entre os diálogos e o monólogo que se consolidam. No entanto, diferente de sua posição de afastamento de Vítor, no capítulo anterior, aqui o narrador entrega a narração a Aníbal, fortalecendo ainda mais a relação estabelecida entre os dois desde o início do romance. Se no primeiro capítulo, há uma submissão hierárquica na ordem: autor implícito $\rightarrow$ narrador, Aníbal $\rightarrow$ Sara $\rightarrow$ outras personagens; e no segundo: autor implícito $\rightarrow$ narrador, Aníbal, Vítor $\rightarrow$ outras personagens; aqui ocorre que, pela primeira vez na narrativa, o narrador muda de posição nessa hierarquia, constituindo-se assim a ordem: autor implícito $\rightarrow$ Aníbal $\rightarrow$ narrador $\rightarrow$ outras personagens ${ }^{16}$.

Em contraposição a esse narrador que desaparece, surge um Aníbal que "fala" desesperadamente, com Sara, com Ximbulo, com sua árvore, consigo mesmo. Nessas falas, parece realizar uma retrospectiva na tentativa de entender os caminhos que se seguiram a libertação. Trata-se de um herói inconformado com a realidade vigente passando a limpo a história, na tentativa de entendê-la.

Ao ceder a voz para a personagem, tomando-a de seu narrador, o autor implícito realiza um movimento que faz colidir dois caminhos: o narrador parece se perder perante a perspectiva do herói que, por sua vez, narra com perplexidade a história que vive e observa. Os fatos externos são apresentados vez ou outra através dessa perspectiva, mas a maior imersão ocorre no interior de Aníbal, tentando trabalhar com sua própria frustração. O que parece estar em cheque aqui, com maior força, é justamente a ideologia do próprio autor implícito, que como argumentamos no início dessa análise, coincide com a ideologia do herói e é marcada pelo projeto inicial do

\footnotetext{
${ }^{16}$ É importante notar que a autoridade do autor implícito, pelos motivos já apontados por Wayne Booth, mantém-se do começo ao fim, apenas "encaixando as peças" que irão a ele se submeter.
} 
MPLA, de um país com igualdade social, fundamentado principalmente pelo nascimento do Homem Novo.

Se a natureza se torna amigável, exatamente o inverso se desenha na realidade presente, pautada pela hostilidade de um país afundado na pobreza, na guerra, na ambição desenfreada daqueles que outrora foram guerrilheiros "puros" (nas palavras de Aníbal), para se transformarem em usurpadores do Estado (tais como Mundial). Isso tudo ocorre, segundo o próprio herói nos revela, nas entranhas do partido. É a falência do homem novo, a falência, em termos mais catárticos, de um projeto pelo qual se lutou. Diante desse fato, o narrador perde sua capacidade de ação/intromissão narrativa, porque a característica principal que o tornava um narrador participativo no início do romance era a utopia, vinculada a determinado projeto, que parece estar perdida. Para revelar a desilusão utópica, aparece-nos o herói isolado que, na contramão da sua posição de homem ideal para vencer a luta do início do romance, torna-se aqui a fulguração da distopia. No entanto, ele se mantém íntegro (o que fica claro pelo ritmo narrativo que remete à tranquilidade), ainda que sua capacidade de ação se torne absolutamente restrita ao pouco movimento que pode fazer na ilha a seu redor, mantendo assim a mesma composição moral que lhe foi construída desde o início do romance.

Todavia, se na ação narrativa esse herói perde espaço e força devido ao contexto delineado e ao espaço restrito no qual atua, na estrutura narrativa ele se fortalece através da própria palavra ${ }^{17}$. O direito a palavra é seu e será através de seu olhar que teremos contato com esse novo momento angolano. Portanto, temos que se há um narrador perplexo que se apaga em cena, há um herói lúcido que tenta ampliar a capacidade de interpretação da realidade para, quem sabe, nela voltar a atuar. Ao fazer essa opção, o autor implícito ilumina o seu locus narrativo: o narrador que se embalava no projeto utópico perde voz nesse novo universo, construído principalmente pela distopia. Ao contrário disso, o herói, sempre lúcido, continua simbolizando aquilo que se esperava dos homens disposto a construir a nacionalidade angolana, convicto de suas posições iniciais, ainda que completamente desiludido com a realidade. Mesmo que sua única alternativa diante dos fatos, para manter-se íntegro às suas convicções, seja o

\footnotetext{
17 "Quando ela vem, sou eu que falo. Aliás, esse é um terrível defeito que tenho. Acabo sempre por ser o único que fala numa conversa. Por isso me chamaram de Sábio. Primeiro foi a gozar, ironia pura. Acabei por adotar como nome de guerra e perdeu o caráter de gozo." (PEPETELA, 2013, p. 251).
} 
isolamento. Tais posicionamentos determinam, além da frequência de fala de cada um, a autoridade narrativa que se impõe, fazendo com que haja a inversão da ordem inicial.

Aníbal vive dois episódios que o ajudam a ponderar os dissabores da realidade vigente e repercutem na sua postura: o reencontro com Sara e o enfretamento de seu monstro de infância (um polvo). Do reencontro com Sara, há, finalmente, o desenlace amoroso cuja expectativa se desenhou desde o início do romance. E é principalmente através dos diálogos com ela que Aníbal irá analisar a realidade que o cerca. Ressaltese, nesse sentido, a presença de Sara como força motriz da utopia no primeiro capítulo através dela a presença da utopia é ainda presente, mesmo que haja indícios de seu esgotamento. Aníbal nota aqui uma Sara "envelhecida e cansada", ainda que ela insista em ter esperança e, por isso, acabe por se reconstituir como sendo capaz de ter alguma perspectiva positiva diante de toda a adversidade que se configura.

Ele notou. Sara estava envelhecida, Devia ter uns quarenta e seis anos, como ele. Não, ela era um ano mais nova. Muitos cabelos brancos, rugas na testa. Mas não era tanto isso. A maneira como se vestia, como se sentava, como fumava o cigarro, tudo nela tinha ar desmanzelado. Muito diferente daquela Sara elegante, sem ostentar luxo, que conhecera em Lisboa. Foi a estadia em Paris? Também não. Quando se encontraram em Luanda, quatro anos antes, ela mantinha a mesma aparência de sóbrio refinamento, com a bata branca do hospital. E agora usava os óculos em permanência. Os últimos anos de vida devem ter sido difíceis, com o seu comboio de desilusões e dificuldades. (PEPETELA, 2013, p. 248).

Embora o narrador se apresente pouco nesse capítulo e em nada lembre aquele narrador participativo de $A$ casa, há, entre este e aquele capítulo, na atitude do narrador uma semelhança - a solidariedade e cumplicidade para com a personagem a quem cede a voz. Fato evidenciado quando, por exemplo, intercepta a voz de Aníbal para a ele próprio justificar, como no trecho "Ele sozinho não podia mudar o Mundo, já nem tinha forças para tentar." (PEPETELA, 2103, p. 259). Nesse sentido, é importante notar que ainda que o narrador se submeta, na ordem que aqui chamamos hierárquica da voz narrativa, ao herói e ao autor implícito, devido à complexidade do momento narrado que lhe causa certa letargia, seu vínculo com o herói se mantém claramente.

Podemos dizer que nesse capítulo atua o narrador com certo constrangimento. Tudo o que antes era claro - o inimigo comum, as necessidades da luta, as obstruções a serem superadas para se lutar - é aqui impregnado de certo obscurantismo que, ao que parece, 
só Aníbal poderia elucidar, com sua voz crítica que permanece. O narrador se cala e o herói fala de maneira insistente, e sua fala contradiz suas aparências perante o outro: falando ele expõe sua lucidez. Portanto, segundo Sara, tem a aparência de um profeta, e sua voz desponta na narrativa com a análise sólida de uma difícil realidade presente.

Sara e Aníbal se mantém os mesmos, apesar das circunstâncias, desde o início da narrativa e do desenlace amoroso que se dá entre eles, há um fortalecimento das possibilidades futuras. Com essa união, vemos nascer no seio da narrativa a velha voz dissonante à ideologia vigente, tal qual ocorreu no início do livro, como leitmotiv do autor implícito. Se lá a voz que sobressaía era a do próprio autor implícito, projetando a narrativa na contramão da ideologia colonial, aqui a voz que se sobressai é a do herói, apoiado por Sara, projetando a narrativa na contramão da ideologia da nova política angolana, com seu projeto socialista frustrado, e mantendo-se fiel a ideologia que inicialmente foi figurada na voz do narrador, (e que se assemelha com a perspectiva inicial do próprio MPLA).

Da união com Sara, surge a força para que Aníbal enfrente seu monstro de infância. Do embate, sai vitorioso e derrotado, simultaneamente. Vitorioso pela morte do polvo, derrotado pela insignificância dessa morte perante aquilo que imaginara, "era um polvinho, não o monstro marinho contra o qual combatera" (PEPETELA, 2013, p. 304). Há, no entanto, nesse movimento, uma superação a qual Aníbal se submeteu ("Nunca mais seria como antes, ia faltar sempre o polvo" (PEPETELA, 2013, p. 305)) e temos aqui um tom nostálgico que irá, desde já, apontar para as premissas que se sobressairão no último capítulo. O silêncio da árvore de Mussole no epílogo corrobora para essa nostalgia.

\subsection{Estilhaços da realidade - Malongo ao centro}

\section{O tempo (a partir de julho de 1991)}

Diferente do que podemos observar na introdução dos capítulos anteriores, cujo tempo sempre está bem definido, o último capítulo do romance se inicia por um tempo 
em aberto, a partir de julho de $1991^{18}$. Iremos tratar disso mais adiante, mas é importante frisarmos que esse tempo em aberto, desde já, aponta para a continuidade da história, ainda que o romance esteja no seu último capítulo.

O capítulo é aberto com uma alocação temporal, "trinta anos" (PEPETELA, 2013, p. 315), de um narrador que, logo percebemos, volta a narrar utilizando o fluxo de consciência. O tempo, que remete ao início da narrativa, é o tempo que Malongo ficou afastado de Angola, e saberemos que dele se trata logo nas primeiras páginas. É possível perceber que existe uma estrutura narrativa que se configura no romance da seguinte forma: no primeiro e no último capítulo, o narrador inicia seu percurso pelo enredo utilizando o processo do fluxo de consciência, no segundo e no terceiro, do processo de observação. Entretanto, se há uma opção narrativa que aproxima, há, ao mesmo tempo, uma postura do narrador que afasta nessa configuração capitular. Já mencionamos que, apesar da semelhança inicial dos capítulos 2 e 3 há uma atmosfera que é desenhada de maneira contraposta. Se em 2 tudo gera a hostilidade por um Vítor, transformando-se em Mundial, perdido na floresta, no 3 há uma climatização harmônica entre Aníbal e a natureza, que conflui para uma atmosfera de passividade.

Entre o primeiro e o último capítulo, apesar da semelhança da escolha do processo narrativo (o fluxo de consciência das personagens elegidas) configura-se também uma sensível diferença entre a postura do narrador. Em A casa, um narrador acompanha o fluxo de pensamento de Sara e com ela se solidariza. Sua integração à personagem constrói nesse início do romance um movimento utópico, alicerçado pelos sentimentos dela, que estrutura a narrativa. No entanto, no último capítulo tudo caminha para o sentido inverso: aqui o narrador se mantém afastado da personagem que elege como duplo narrativo por um determinado tom irônico que o irá caracterizar definitivamente a partir de agora.

Temos então mais uma estruturação capitular que se organiza na intersecção, agora, entre os capítulos 1 e 3 e entre 2 e 4 . Tal intersecção é formatada não mais pela coerência de escolha de processo narrativo, mas sim pela empatia criada de certa forma

\footnotetext{
18 Apontamos para duas informações referentes a data que intitula o capítulo e que está relacionada a determinado período histórico angolano: o ano de 1991 é o ano em que Pepetela escreve o romance, conforme citamos no início dessa análise. O ano de 1991 é também o ano em que, na história de Angola, dá-se uma trégua na guerra civil iniciada desde o fim do regime colonial. Portanto, esse capítulo parece referir-se justamente ao tempo presente e, não por outro motivo, é ele que encerrará a narrativa.
} 
entre o narrador e as personagens. Em A casa e $O$ polvo, o narrador compartilha a voz narrativa com as personagens de maneira a aproximar-se delas, num processo que aqui chamamos de solidariedade ou cumplicidade narrativa. Portanto, podemos dizer que os valores das personagens sobrepõem-se, comungando dos valores do próprio narrador. É importante frisarmos que se, por um lado, no terceiro capítulo a voz é cedida, em grande parte do enredo, ao herói, no primeiro, embora o fluxo de consciência mais acompanhado seja o de Sara, é ainda a perspectiva de Aníbal que se estabelece na estruturação realizada pelo autor implícito e narrador.

Já em A chana e $O$ templo, contrariando essa postura narrativa, o narrador estabelece com as personagens eleitas (Vítor e Malongo, respectivamente) uma distinção de vozes, caracterizada, principalmente, pela ironia. Dessa maneira, o narrador retoma um pouco a voz narrativa, excepcionalmente apagada no capítulo anterior e, ainda que não com a mesma força dos dois primeiros capítulos (principalmente o primeiro) estabelece sua voz crítica alicerçada pela ironia, que remete para a negação. É importante notarmos, portanto, que, a despeito do processo narrativo escolhido para e pelo narrador (se ligado ao fluxo de consciência se ligado à observação de ações), a aproximação definida pela postura do narrador (se solidária/cúmplice ou se irônica) oferece o tom da ideologia que a pauta, apontando para o locus enunciativo do narrador e, principalmente, de seu autor implícito.

Se a ironia é um recurso que pressupõe o diálogo direto entre enunciador e enunciatário (Brait, 2008, p. 75) ou, em outras palavras, entre o ironista e o interpretador (Hutcheon, 2012, p. 28), podemos concluir que através da percepção irônica o autor implícito coloca em contato direto e de cumplicidade narrador e leitor, uma vez que o entendimento da própria ironia pressupõe a interpretação do leitor acerca da intenção oposta aquilo que se fala (negação), respaldado a partir de todos os valores circunscritos no caráter das personagens das quais se aproxima sem inferência irônica (Aníbal, em destaque como protagonista, e Sara). E assim, nesse capítulo, Sábio, que já havia se colocado como contraponto de Mundial em A chana volta a ser contraponto de Malongo, agora com mais ênfase do que em A casa, quando já se apresentava como seu opositor em disputa pela atenção de Sara.

Temos então que Malongo ressurge na narrativa, depois de uma ausência de dois capítulos e agora como, em parte, o duplo de um narrador irônico e distante de si. Essa 
postura do narrador com relação a Malongo faz crescer nessa personagem a áurea de predador, que, como veremos em nossa próxima análise, intensificar-se-á na relação narrador-Caposso, presente em Predadores. No entanto, o que é imprescindível que notemos aqui é que a permanência da ironia sempre relacionada a Malongo, (e a Vítor e Elias, aqui seus comparsas), alicerça o tom da crítica que se constitui perante as ações dessas personagem, que representam o inverso do projeto utópico que substancializou o início do romance.

Através do recurso irônico temos contato, portanto, com o Malongo empreendedor que não hesita em colocar em cheque todos os valores anunciados outrora no préindependência, ou seja, no primeiro capítulo que caminha para o inimigo comum - o poder colonial. Malongo, que naquele momento era a única personagem não ligada ao socialismo, finalmente percebe a oportunidade de seus valores sobressaírem àqueles antigos ideais presentes no início da narrativa.

\begin{abstract}
Até eu mesmo, que nunca me quis molhar, acabo por me envolver nestas conversas, se quero fazer negócios. Mas são bem mais interessantes do que aquelas da juventude, em que todos queriam mudar o Mundo e só discutiam coisas abstratas, como liberdade, igualdade, justiça social. Então era uma chatice, vinha sempre com palavras que ninguém entendia, mais-valia, exploração, luta aqui, revolução ali. Agora é melhor, trata-se sempre de como enganar o outro ou o Estado, para se enriquecer mais depressa. Isso ao menos é claro e é positivo, é a única política que pode interessar. (PEPETELA, 2013, p. 329).
\end{abstract}

No entanto, para contrariar os caminhos de sua argumentação, surgem no início da narrativa duas novas personagens que irão contrabalancear seus preceitos, apresentando uma alternativa para essa articulação entre o passado e o presente que começa a se desenvolver, fortalecem Aníbal e opõem-se a Malongo. Judite, filha de Sara com Malongo, e Orlando, seu namorado, representam a nova juventude e é através do olhar deles que o narrador aponta para alguma fecundidade do projeto passado. Para tanto, Sábio será resgatado por essa nova juventude, e apresentado em sua lucidez, como exemplo, o que aponta para a retomada de antigos ideias apagados pelo angustiante presente:

- Por quê? - perguntou Judite. - Por que vem como o povo vem? Ele não tem carro e de avião é aquela confusão que todos conhecem, exceto para os VIP, claro. Acho bonito vir assim, no cimo dum camião. E goza melhor a beleza das paisagens. 
- Estivemos com ele na Caotiinha o ano passado - disse Orlando. Gostei muito de o conhecer. Não é louco, nem pouco mais ou menos. Mas é demasiado lúcido para o gosto e certas pessoas, viu o filme todo muito antes do que ia acontecer. Amargo sem dúvida, mas isso só mostra sua lucidez. (PEPETELA, 2013, p. 330).

Apesar dessa renovada oposição, agora entre o passado e o futuro, a narrativa se mantém na maior parte do tempo imersa num presente desolador, e isso é caracterizado pela relação narrador-Malongo. Apesar de acompanha-lo ironicamente, o narrador tem sua força relativamente esvaziada pelo apagamento, novamente, de sua voz narrativa, tomada aqui pelos diálogos que se estabelecem principalmente entre Malongo, Vítor e Elias nas negociatas para tirarem do Estado o maior lucro possível, através da criação da Igreja da Esperança e da Alegria de Dominus.

Devido a esse aspecto de um narrador cuja voz se enfraquece, temos que aqui a estrutura do que antes chamamos de hierarquia narrativa se redesenha da seguinte maneira: autor implícito - Malongo, Aníbal - narrador - outras personagens. Nesse contexto, novamente o narrador aparece em terceiro lugar hierárquico, deixando com Aníbal a função de se contrapor a predominante voz de Malongo, e isso ocorre devido às suas ações e ao resgate que a nova geração faz de si. Mais uma vez, portanto, nesse romance fica explícito que a voz de autoridade predominante, além da autoridade impressa pelo autor implícito, é a de Aníbal, o que demonstra uma intrínseca cumplicidade entre essas duas entidades narrativas. Autor implícito e protagonista comungam, portanto, dos mesmo valores e a narrativa é construída a partir desses valores.

Dessa forma, podemos dizer que o narrador é interceptado por ambos e se sua posição, no início da narrativa, era de igualdade com o protagonista (ambos no mesmo lugar de hierarquia da voz narrativa), agora, nesse momento, o cenário muda, porque o narrador se emudece novamente na mesma medida em que o protagonista volta a cumprir seu papel de espelho balizador das ações alheias. Por essa lógica, e longe de representar em tal alocação narrativa um significado negativo, o que parece ser estabelecido é, pelo contrário, a positividade de uma posição que se fortalece e projeta esse final da narrativa para os mesmos ideais presentes no início do romance, durante a período de formação da luta de libertação. 
Assim sendo, Aníbal não sofre transformação e, mediante o silenciamento de um narrador que parece perplexo e constrangido diante da realidade vigente a partir do fim da luta, ( $O$ polvo e A chana), apresenta-se como força ideológica da narrativa, contaminando, ele próprio, o narrador, que, como podemos notar, acompanha seus passos. Podemos recuperar então o início de nossa análise que aponta para uma intersecção dos valores do autor implícito, o narrador, o protagonista e o "Homem Novo" proposto no projeto de libertação do MPLA. Aníbal, sendo ele a representação desse homem ideal, intelectualizado guerrilheiro-revolucionário, amarrado aos valores socialistas que instigam a luta por uma sociedade mais justa, desponta, ao longo de toda narrativa como - 1. Infiltrando-se na voz narrativa como alicerce da estruturação dos valores que irão cerceá-la, 2. Contrapondo-se aqueles que com ele não comungam o mesmo valor, o que faz o narrador auxiliá-lo nesse embate utilizando certo tom discursivo irônico.

Podemos, portanto, através dessas duas posturas narrativas (cumplicidade e ironia) apontar para os caminhos ideológicos vinculados a esse narrador, ao protagonista e ao autor implícito. Nessa observação, salienta-se que os valores que emergem da formação do movimento de libertação do início da narrativa (qual seja crença na construção de uma sociedade mais justa do que a antiga sociedade colonial) é mantido ao longo de toda a obra, uniformizado pela postura do protagonista, e pela posição do narrador num movimento de afirmação (cumplicidade) ou negação (ironia). Diante de um cenário de projeto frustrado, cuja justiça fica em outro plano e sempre à mercê dos interesses dos que buscam enriquecer pelo poder, o narrador perde sua potência intromissiva - muito presente inicialmente - e, perplexo, cala-se, apresentando ao leitor a letargia que tal frustração provocou. Afastando o narrador, o autor implícito puxa definitivamente para o centro da roda a voz do homem ideal inicialmente postulado e define a sua posição crítica.

A despeito da voz de Malongo que surge como duplo narrativo nesse capítulo, o narrador ensaia sua posição crítica, assumida já pelo autor implícito, através da ironia. E a ironia, portanto, será a chave catalizadora da enorme aproximação ideológica que há entre este narrador e o narrador de Predadores, e, com ênfase, entre o autor implícito daqui e o de lá, como veremos a seguir. 
A geração da utopia é finalizada com o tempo da narrativa em perspectiva aberta, como procuramos indicar inicialmente, o que aponta para a continuidade do processo histórico, sempre passível de mudança. Coincidindo com tal perspectiva aberta do contexto no qual foi criado (a negociação da guerra civil angolana no ano de 1991), podemos apontar para um certo teor positivo que se sobressai depois do torpor provocado pelo o culto a Dominus, que parece a todos hipnotizar. E o epílogo final vem para confluir para esse sentimento de continuidade: "Como é óbvio, não pode existir epílogo nem ponto final para uma estória que começar por portanto". Portanto, em seu momento derradeiro, o autor implícito volta a se afirmar como voz da autoridade no romance, remetendo o final para o começo, e à possibilidade do (re)início.

\section{PREDADORES}

Pepetela publica Predadores em 2008, época em que o fim da guerra civil angolana completava seis anos. De maneira geral, o texto narra a trajetória de Vladimiro Caposso: a juventude pobre, a incrível ascensão financeira e social que conquista graças as suas ações violentas e corruptas, no cenário de uma Angola pós-independência e, por fim, sua queda. A partir de sua história, contada de forma não linear (ao longo de três décadas - 1975/2005), temos contato com os caminhos e descaminhos do "estado das coisas" no país independente, quer dizer, a corrupção política, o abuso do poder político aliado ao econômico, a usurpação de bens e riquezas por uma elite ligada ao Estado que se constitui. Vladimiro Caposso, nascido pobre, num país ainda colonial, aprende a usar todos os artifícios necessários para ascender financeiramente através de um sistema político que, após a independência, finca-se na corrupção e nas burocracias do Estado. Ao longo dos anos, reinventa uma identidade compatível a de homem rico e poderoso, cujos mandos e desmandos incidirão sobre a estrutura social contribuindo substancialmente para as abissais desigualdades sociais do país. A narrativa se desenvolve em terceira pessoa, com um narrador que, ainda que se aproxime do protagonista, através da permissividade do fluxo de consciência, dele se vai dissociando ao máximo, com recursos como a ironia e o comentário para poder desnudar o caráter de Caposso. 
Se em A geração da utopia o tempo retratado é do início da eclosão da guerra de libertação até o momento em que houve no país um intervalo entre a guerra civil e as primeiras eleições; em Predadores o tempo a ser contemplado é do pós-independência (correspondente ao capítulo 2 de $A$ geração) até o fim da guerra civil, retratando o acelerado declínio das projeções utópicas ligadas ao movimento de libertação do país e sua também acelerada entrada no mundo do capital com os interesses de suas então emergentes elites políticas. Portanto, dentre suas confluências e diferenças podemos apontar que o tempo retratado pelas narrativas se aproxima relativamente e também relativamente se diferencia. Esse tempo retratado, portanto, indica sua importância à medida que contribui para a constituição das vozes narrativas presentes nas obras, que serão o foco dessa análise comparativa.

Em A geração da utopia utilizamos para a análise a linearidade narrativa, separandoa por capítulos, uma vez que a voz narrativa se comprometia, em cada um deles, com uma personagem diferente que a ajudava a se constituir, a lembrar: Sara, Vítor (Mundial), Aníbal (Sábio) e Malongo. A voz do narrador, como tentamos destacar, circunstanciava-se a partir da relação que se estabelecia entre ele próprio e a personagem que lhe fazia o duplo. $\mathrm{E}$ isso foi determinante para o tom que o próprio narrador assumia: de cumplicidade (afirmação) ou de ironia (negação).

A ironia presente em A geração da utopia se desenhava principalmente quando a voz narrativa se duplicava através do fluxo de consciência das personagens com as quais não tinha uma ideologia alinhada, portanto com aquele que era negado por três entidades narrativas: o narrador, o autor implícito e o protagonista. Sendo assim, ela esboça os primeiros sinais irônicos com Vítor, em A Chana, que vai se transformando em Mundial, e se fortalece no último ato narrativo, já com o empresário Malongo, em $O$ Templo. Ao contrário dessa atitude presente lá, em Predadores a ironia é característica fundamental na estruturação do ato narrativo, que, por sua vez, também aponta para uma falta de alinhamento ideológico entre o narrador, o autor implícito e a personagem da qual ficam próximos a maior parte do tempo: Vladimiro Caposso.

Essa diferença que se faz entre as obras marcará a diferente estrutura analítica que será realizada a partir daqui. Embasando-nos na ideia do tom irônico como elemento constitutivo da voz que narra Predadores, recorreremos a três divisões para a análise: a primeira procurará identificar uma ironia latente na voz narrativa, a partir da ascensão 
de Vladimiro Caposso; a segunda apontará para certo silenciamento da ironia possível pela aproximação que ocorre entre o narrador e Nacib e Sebastião Lopes, principalmente; na terceira e última divisão serão levantados os pontos de construção da ironia propostos pelo autor implícito. Acreditamos que se em A geração da utopia a posição ideológica do narrador fica caracterizada principalmente pela postura que ele assume de acordo com a personagem a que está imbricado, formando o duplo, em Predadores é a oscilação do tom irônico que aponta para esse posicionamento ideológico da voz narrativa. Ao propormos um diálogo entre esses narradores, procuramos demonstrar que, ainda que haja semelhança em suas posições ideológicas, a forma privilegiada para apresenta-las se diferencia e essa diferença aponta, ao que nos parece, para o contexto externo que acaba por se internalizar e tornar-se elemento estruturante da própria obra. Podemos notar, assim sendo, que há uma mudança de perspectiva com a aproximação proposta (do herói - Aníbal; e do anti-herói - Caposso) e quanto menor a afinação ideológica entre protagonistas e narradores, maior a intensidade do tom irônico de sua voz, que direciona a leitura para os valores dissonantes que a compõem a partir do movimento de negação. Nesta análise comparativa que trata das duas obras de Pepetela, A geração da utopia e Predadores, procuraremos investigar o percurso que associa e dissocia suas vozes narrativas.

\subsection{Da ironia presente}

Invertendo a lógica do início de A geração da utopia, que possibilitava certa prospecção positiva, com o narrador apoiado na romântica e utópica Sara, Predadores é inaugurado com uma apresentação brutal que aponta para a negatividade de seu protagonista: a cena de um assassinato cometido por "o homem de impecável fato azul", chamado Vladimiro Caposso (PEPETELA, 2008, p. 15). A violência da execução do casal cometida por Caposso aponta para o exato inverso do que parecia ser o cenário 
externo a cena do crime, no qual se comemorava uma possível paz, em setembro de $1992^{19}$ :

Caposso apontou com frieza do lado de fora do quarto, retendo a respiração, como aprendera da arte de bem disparar. Esvaziou o carregador da pistola. Os tiros foram bastante abafados pelo barulho atroador da carreata. Entrou no quarto, empurrou com o cano da pistola o corpo do homem morto. Verificou que ela também estava morta, três buracos perto do coração. Nem souberam porquê morreram, foi pena (...). Dava no mesmo. Não era por eles que fazia esta matança, era por si próprio. (PEPETELA, 2008, p. 16).

O narrador-observador persegue Vladimiro pelas páginas iniciais e vai, dessa forma, construindo sua imagem. Ironicamente são os indícios de paz que lhe serve de álibi para cometer o crime:

Nesses tempos conturbados de mudanças políticas, fim do regime de partido único e suspensão da guerra civil, seguidos de uma campanha eleitoral problemática, tinha resolvido voltar a olear a pistola que possuía há muito e fez algumas sessões de treino ao alvo no terreno que possuía fora de Luanda. Podia precisar da arma e da sua pontaria apurada para se defender e à família, ninguém podia prever um futuro tranquilo. Portanto, arma tinha. Bastava coragem para resolver o assunto e dispor as coisas de modo a não ser incomodado pela polícia. (...) Vladimiro Caposso pela primeira vez sorriu, a audácia triunfava sempre, ele sabia jogar com a psicologia do momento, por isso chegara ao ponto de vida onde estava. (PEPETELA, 2008, p. 21).

A primeira manifestação da voz irônica ocorre, apenas, com o advento de um segundo narrador, cuja voz está em primeira pessoa, emitindo um comentário, e que aqui chamaremos de autor implícito, que lembra ao leitor o seu poder de execução do ato narrativo, estipulando as digressões e progressões que irá utilizar:

[Qualquer leitor habituado a ler mais que um livro por década pensou neste momento, pronto, lá vamos ter um flashback para nos explicar de onde vem este Vladimiro Caposso e como chegou até o que é hoje. Desenganem-se, haverá explicações, que remédio, mas não agora, ainda tenho fôlego para mais umas páginas sem voltas atrás na estória, a tentar a História. E desde já previno, este não é um livro policial, embora trate de uns tantos filhos de puta. Mais previno que haverá muitas misturas de tempos, não nos ficaremos por este ano de 1992, em que houve as primeiras eleições, iremos atrás e iremos à frente, mas só quando me apetecer e não quando os leitores supuserem, pois democracias dessas de dar a palavra ao leitor já

${ }^{19}$ Conforme já tratamos brevemente, há a partir de 1990 um acordo de paz entre MPLA e UNITA, resultante dos esforços empenhados para que houvesse no país as primeiras eleições para presidência da república. Angola se torna então um país multipartidário. Sobre isso, iremos nos debruçar mais tarde, quando discutirmos o aporte teórico. 
fizeram muita gente ir parar no inferno e muito livro para o cesto de lixo.] (PEPETELA, 2008, p. 21).

A partir dessa abertura irônica proposta pelo autor implícito, um elemento novo é injetado à narrativa: o fluxo de consciência de Caposso, que se torna determinante para marcar a ironia na composição da voz do narrador em terceira pessoa. Dessa maneira, temos que a narrativa será caracterizada a partir, principalmente, de três vozes que contam a história, e que, entre si, possuem em comum o tom irônico: o protagonista, que em todos os seus atos, ou na maior parte deles, demonstra um completo desprezo para com o outro; o narrador, que se aproximando de Caposso através do fluxo de consciência, faz com ele seu duplo, assumindo o tom irônico, à medida que faz reverberar essa ironia para o próprio protagonista, ao narrar sua história; e o autor implícito que divide suas ações narrativas em duas: a que tende a explicitá-lo, quando ativa sua própria voz, que emerge em momentos pontuais, com marcas textuais que a diferenciam (colchetes e itálicos), e a que se apresenta mais implícita por ocorrer na estruturação não-linear da história, ambas serão entoadas pela vertente irônica.

Podemos destacar, então, logo no início do romance, que as três vozes constituintes da narrativa (narrador, autor implícito e protagonista) possuem em comum e em cumplicidade o tom irônico que se organiza e se intensifica de modo diferente entre os três, apontando para a diferente visão de mundo que se configura a partir do ato de narrar. A ironia é, portanto, usada para negar valores que essas vozes não compactuam: Caposso trata com ironia todos aqueles que a ele se opõem (tanto os que não compartilham de sua ideologia, quanto os que com ele disputam o poder); o narrador nega, com sua ironia, o próprio Caposso; e o autor implícito nega, ao mesmo tempo, os valores de Caposso e os limites impostos ao ato narrativo, afirmando sua autoridade.

A atmosfera inóspita construída pelo primeiro momento narrativo conflui para uma expectativa negativa da história a ser narrada. Ainda que exista um ensaio de fim de guerra como cenário de fundo, o assassinato assim delatado nas primeiras páginas imputa à narrativa a ausência de cordialidade entre as personagens e isso está relacionado, principalmente, a forma de atuação do protagonista que devidamente tutelado por um narrador que coaduna de sua ironia, induz o leitor a verificar a negatividade dos atos. A família de Caposso está de saída para Portugal, com o fim da guerra civil ninguém sabe ao certo o que irá acontecer em Angola, principalmente com 
aqueles que, como o "chefe" Vladimiro, beneficiaram-se da política que vinha sendo realizada até então.

Há meses que os responsáveis e gente com algum dinheiro tinham posto as famílias a bom recato, não era difícil imaginar o processo a descambar e os da oposição a ganharem as eleições e a reprimirem tudo o que estivesse ligado ao antigo regime, ou no pior dos casos uma nova guerra a estoirar, mesmo em Luanda, onde antes nunca tinha havido nada para além de umas escassas bombas terroristas. (PEPETELA, 2008, p. 29).

Junto da primeira cena do homicídio, que por si já difunde o caráter negativo desse protagonista, temos ainda algumas outras descrições sobre a sua forma de atuar que, elucubradas, fixarão a primeira impressão do homem. Vladimiro é ambicioso, austero, ácido, impetuoso, rude. Não há, no universo de suas ações relatadas, qualquer indício contrário à negatividade de sua ação inicial. O protagonista exerce seu poder para com todas as personagens que se aproximam dele e a caracterização que faz delas é condizente com a sua maneira egocêntrica de ver o outro. Explicita assim a subserviência de Fátima Magricela e José Matias ("Fátima se babava (...). Ele percebeu a vantagem de ter alguém absolutamente fiel a seu lado, era outro José Matias, mas para diferentes usos" (PEPETELA, 2008, p. 26), a opressão a que submete Bebiana, a ojeriza que sente do Nunes-cara-de-rato ("Grande jeito, filho-da-puta", (Idem, p. 36)), a chateação que lhe causam os intelectuais como Olímpio d'Alva Ferreira ("você lê, eu enriqueço", (Idem, p. 38)). A negatividade projetada por sua voz irônica encontra respaldo na voz do próprio narrador que, absorto no seu fluxo de consciência, enaltece e amplia a hostilidade que lhe é singular. O autor implícito, por sua vez, também ironicamente, aponta para a autoridade de seu próprio ato narrativo ("iremos atrás e iremos à frente, mas só quando me apetecer e não quando os leitores supuserem”, idem, (Idem, p. 21)). Assim, a atitude presente nas três vozes que compõem a narrativa nesse primeiro momento do enredo projetam o romance para o universo da autoridade e da austeridade, duas características fulcrais da construção do anti-herói cuja história será narrada.

No segundo capítulo, no entanto, há uma quebra desse clima negativista com o aparecimento da figura de Nacib que resulta em uma considerável queda do tom irônico e da crítica ácida da voz do narrador. A apresentação da cena inicial realizada pelo narrador transfigura, nas entrelinhas, como veremos a seguir, a apresentação dos 
contrários, dos contrapostos, que ocorre na relação Vladimiro e Nacib. A construção de Nacib será executada pelo caminho contrário à construção do próprio Vladimiro, sem o pressuposto da toada irônica.

Nasceu rapaz e ficou Nacib, podia ser de outra maneira? Complicado foi registrar o nome do menino, a conservadora não queria aceitar, vigoravam os regulamentos do tempo colonial com uma pesquena alteração, tinha de ser ou nome de origem nacional ou da Bíblia. (PEPETELA, 2008, p. 44).

Tal estruturação dos dois primeiros capítulos evidencia, de certa forma, a estruturação do ato narrativo que se desenha através de duas atitudes principais, como pretendemos apresentar nesta análise: a ironia latente e a ironia silenciada. Se em $A$ geração da utopia tínhamos um narrador que se tornava cúmplice ou contrário à personagem com a qual se ligava, ao estabelecer uma voz conjunta, aqui temos um narrador que fará o mesmo caminho, mantendo-se, entretanto, mais ou menos irônico de acordo com a personagem que lhe está próxima. Da singularidade que se apresenta podemos destacar que enquanto em A geração da utopia há um narrador que ensaia a sua voz irônica ao final, com o cenário degradante que vai se apresentando a partir da ascensão de Malongo, “(...) acontecesse o que acontecesse, eles não tinham nenhum negócio juntos. Na melhor maneira africana, o acordo foi celebrado com uma garrafa sem papéis, nem testemunhas" (PEPETELA, 2013, p. 360) em Predadores o tom irônico sobrepõe-se como característica da narração na maior parte do tempo, em um cenário já degradado pela atuação de Vladimiro. Esse narrador, ao se aproximar do protagonista anti-herói, (ao contrário da aproximação narrador-herói que se dá em $A$ geração) utiliza-se da ironia para demarcar os valores dissonantes: “(...) mas dinheiro também aparecia facilmente, o governo era generoso, oferecia-o aos amigos de um círculo muito restrito." (PEPETELA, 2008, p. 38).

Dessa maneira, faremos uma divisão analítica de acordo com essa progressão irônica. Começaremos por analisar a ironia latente e depois verificaremos seus silenciamentos. Observaremos ainda a ironia sobreposta ao enredo proposta pelo autor implícito, para por fim podermos observar o que essa diferença nos indica, e o que indica em relação $A$ geração da utopia. 


\subsection{A ironia latente: o narrador que acompanha Vladimiro Caposso}

Como destacamos até aqui, a construção de Vladimiro Caposso acontece desde o início através do impulso gerado pela negatividade de seus próprios atos. Uma vez iniciado o contato com a personagem através do frio homicídio que executa no início da narrativa, suas ações de agora em diante serão refletidas a partir da imagem fixada por essa violência. Ainda que o romance contemple quatro décadas que compõem seus blocos narrativos ${ }^{20}$, a inauguração do romance apresenta o ano em que Vladimiro Caposso é um poderoso capitalista no cenário turbulento de uma Angola agitada pela disputa pelo poder. A ironia, portanto, não fará só parte da voz narrativa, fará, mais que isso, parte da atitude narrativa que aqui se condensa.

Ao optar por iniciar o livro a partir do meio, ou seja, pela década que dentro da temporalidade proposta pela narrativa corresponde ao ápice da ascensão de Vladimiro (setembro de 1992), o autor implícito propõe que logo no início nos deparemos com um Vladimiro Caposso no auge do seu poder predatório. Uma vez formatada essa imagem, teremos contato, ao longo da narrativa, com momentos de digressão e progressão do tempo narrado, sempre, como haveremos de discutir, de acordo com a intenção do autor implícito. No entanto, para realizarmos essa análise e pontuarmos a voz irônica que nela se vai formatando, faremos, a princípio, uma reconstrução linear da obra, com o intuito de demonstrar a construção de Vladimiro Caposso na voz do narrador e do autor implícito a partir da configuração irônica, que amplifica o caráter negativo da personagem. Reconstruindo a linearidade narrativa, teremos contato com a ascensão da ironia que parece acompanhar a ascensão financeira e política do próprio Vladimiro que, por sua vez, quanto mais poderoso se torna, mais fortalecida fica a ironia que caracteriza a sua própria voz. Para tanto, realizaremos uma análise dos blocos narrativos presentes na obra.

\footnotetext{
${ }^{20}$ Chamaremos de blocos narrativos os capítulos que estão circunscritos a determinadas décadas. Assim, um bloco será da década de 1970 (composto pelos capítulos 4, 5 e 6, cujos enredos se passam, respectivamente, nos anos de 1974, 1975, 1978); o segundo bloco corresponde à década de 1980 (capítulos 12 e 19, nos anos de 1985 e 1986); o terceiro bloco é da década de 1990 (composto pelos capítulos 1, 2, 3, no ano de 1992; 8, 9 1998; 11, 13, 14 , respectivamente anos de 1997, 1991 e 1995); e o último dos blocos que corresponde aos capítulos cujo cenário é a década de 2000 (7, 10, 15, 16, 17, 18, 20, que se dividem entre os anos de 2004, 2003 e 2001).
} 
O primeiro bloco que compõe a narrativa correspondente à década de 1970 e apontará para o início da empreitada de Vladimiro na escala de poder que apresenta a partir daí. Nos três capítulos que constituem esse bloco, 4, 5 e 6, que acontecem sequencialmente (diferente de outros blocos interrompidos por digressões e progressões), é desenhada a mudança que começa a ocorrer com Caposso, até aqui José, a partir de seu aburguesamento, iniciado pela "herança" que recebe de sô Amilcar. Em 1974, às vésperas da independência de Angola, momento crucial que marca o fim da guerra colonial, Vladimiro era um rapaz interessado em garotas, que se frustrou por não investir no futebol, e que trabalha honestamente na loja do português Amilcar, em troca de um salário e de um teto. Apesar da ironia se apresentar na voz do narrador desde já, ela não é direcionada diretamente a Vladimiro, e sim a realidade à qual esse momento do enredo está circunscrito:

Logo então alguns céticos teimosamente esquerdistas resmungaram, começa a capitular às delícias do capitalismo, Vila Alice é um bairro pequeno-burguês detestado pelas massas populares, esse MPLA nunca fará revolução proletária. (PEPETELA, 2008, p. 96).

A partir da independência, apresentada no capítulo 5 (novembro de 1975), sob o olhar desconfiado de Sebastião Lopes - que já o sentenciava pequeno-burguês - e a voz narrativa irônica que se fortalece, José se transforma em Vladimiro e muda oficialmente de identidade, reinventando-se. A voz narrativa apresenta sua nova condição ambiciosa:

Caposso entrou em casa como proprietário. Pela primeira vez na vida. (...) Aquilo tudo era seu: um quarto pequeno, servindo de despensa e sua alcova, um quarto maior, servindo de loja, uma casa de banho minúscula agregada à casa, mas à qual só tinha acesso pelo lado de fora. Não parecia grande coisa, mas para quem não tinha nada, era um palácio. (...) Tinha que reforçar as marcas limitando a propriedade, por aduelas, ripas, chapas, o que fosse, fechar aquilo, mostrar isso tem dono, ninguém trespassa. Um dia podia construir verdadeira mansão ali (...). Se deixou cair pra trás no saco, levantou os braços ao ar, sim senhor, sô Amílcar era um bom branco. (PEPETELA, 2008, p. 127).

O último capítulo que compõe esse bloco trata do ano de 1978 (capítulo 6) e, com Bebiana grávida, Vladimiro reforma sua casa e passa a se dedicar à política, tirando alguma vantagem do cargo de motorista que lhe oferecem.

No bloco seguinte, correspondente à década de 1980, Vladimiro definitivamente passa a atuar como homem sem escrúpulos. Em sua escalada para o poder, não mede 
esforços para alcançar seus objetivos segundo nos alerta o narrador, orientado por seu fluxo de consciência: "Era um pequeno-burguês e o sonho de um pequeno-burguês é tornar-se um grande burguês, acumular capital, explorar o povo (agora com minúscula) se preciso" (PEPETELA, 2008, p. 338). Os dois capítulos que compõem esse período narrativo são apresentados, na obra, como parte de grandes digressões temporais. Em 1985, a digressão ocorre a partir de 1997, e nele Vladimiro aceita acusar um guerrilheiro inocente de traição em troca de um cargo político. O capítulo 19 se passa em outubro de 1986, constituindo uma digressão a partir de 2003, e nele, com marcações irônicas muito latentes, o narrador apresenta Caposso abdicando da vida política, depois da frustração em não alcançar o cargo almejado e transformando-se em empresário. Mudase ainda com a família para o Alvalade, outrora já apontado pelo narrador como bairro burguês. E tanto narrador quanto autor implícito corroboram para a construção negativa desse novo posicionamento de Caposso, como podemos observar nas seguintes passagens:

Os da geração anterior, a que tinha lutado pela independência, continuavam nos mais altos postos, sendo os dirigentes políticos e econômicos. Os da sua, muitos treinados na Jota, tinham feito cursos médios de gestores ou contabilistas e entrado nessas empresas estatais e nos bancos. Eram esses que lhe interessavam, tinham as mesmas referências, os mesmo sonhos e, sobretudo, as mesmas ambições, subirem rapidamente na vida, mesmo que fosse preciso trepar por cima de muitas costas. (PEPETELA, 2008, p. 519).

[Não esqueçamos, era a época dos cartões de racionamento. Cada chefe de família tinha um cartão que lhe dava acesso a uma loja determinada, onde comprava a cesta básica para um mês, com especial relevo para as numerosas grades de cerveja. Estas eram importantes, decisivas mesmo para a primeira acumulação de capital, pois algumas famílias prescindiam de beber tudo e as grades sobrantes era revendidas à porta da loja a preços vinte vezes superiores ao de compra. O lucro permitia ou acumulação de dinheiro, logo trocado em dólares nas kínguilas para serem guardados sem depreciação, ou compra de bens suplementares, ou compra de bilhetes de avião para irem adquirir produtos baratos na Europa e revender em seguida em Luanda a preços elevadíssimos, sempre lucrando.] (PEPETELA, 2008, p. 510).

A acentuação irônica que se dá aqui já estava completamente construída na narrativa não-linear, no entanto, é importante notarmos que reconstruindo a linearidade da obra, podemos observar que o narrador adquire um tom cada vez mais irônico com relação a Vladimiro, e o autor implícito, por sua vez, manifesta-se nesse bloco com mais veemência do que no bloco anterior, quando Vladimiro ainda era apenas José, 
construindo assim um tom irônico ascendente de acordo com a ascensão da personagem.

O terceiro bloco narrativo corresponde à década de 1990 é o mais longo de todos os blocos, sendo composto por oito capítulos. Durante o período que corresponde a essa passagem temporal, Vladimiro se torna homem rico e poderoso, através de suas negociatas escusas, que o narrador denuncia:

O jurista tinha razão, concedeu Caposso, não era afinal o que mais temia, tinha casos bem melindrosos em mãos e uma chamada da polítia punha-o sempre tenso, à espera do pior. Apesar de dizer constantemente que dormia como um anjo por não ter nada de sujo na vida, quem não deve não teme... Como se alguém que desfruta de poder, por pequeno que seja, consegue dormir tranquilo... (PEPETELA, 2008, p. 204).

O ano de 1992 inicia o romance com a fatídica cena do assassinato cometido por Caposso. Se durante as duas primeiras décadas retratando Caposso surgem movimentos de transformação que o transfiguram de rapaz ingênuo para uma espécie de homem sem escrúpulo, na década de 1990, já completamente transformado em rico empresário, Vladimiro vai regulamentando o mundo ao seu redor fazendo com que as estruturas de poder e as redes de interesse se movimentem de maneira a lhe beneficiar, uma vez que suas relações políticas garantem a ele impunidade diante de suas ambiciosas investidas contra a carente estrutura social de Angola: "Fome? Só de dinheiro. Quanto mais dinheiro, mais fome." (PEPETELA, 2008, p. 365).

Dessa forma, à medida que Vladimiro se apresenta como mais poderoso, a voz do narrador vai, proporcionalmente, atingido uma ironia cada vez mais latente, apresentando as ações de Vladimiro de maneira próxima ao sarcasmo, construindo sua identidade bruta e inescrupulosa, que enxerga em tudo a vantagem da riqueza. Como podemos notar, a presença do fluxo de consciência do protagonista aumenta o tom irônico que vai sendo fomentado na narrativa:

Ele não tinha veleidades de armar cercos de sedução, era direto e bruto como em tudo na vida, para quê perder tempo com táticas, desenvolver estratégias, armar emboscadas, simular sentimentos? Pãopão queijo-queijo como diziam os portugueses. (...) Anda comigo e tens isto. Senão, limitas-te a contemplar cenas parecidas na televisão, onde os pobres podem estudar, com a desdentada boca aberta, e discutir aquilo e apenas aquilo que os ricos querem mostrar. (PEPETELA, 2008, p. 90-91). 
A ambição que o caracteriza e é capaz de despertar constrangimento até em Mireille, única personagem por quem Caposso parece nutrir verdadeiro sentimento fraternal, é acionada pelo narrador com exageros que correspondem às ideias do próprio Caposso:

Ela tinha aprendido nos textos da escola o que fora a corte de Versalhes e insistiu uma vez na visita mas VC em breve se aborreceu mortalmente, não viemos a França para ver casas mesmo se são palácios cheios de dourados, a ele interessava o ouro apenas como riqueza, e detestava visitas a museus e monumentos, preferia restaurantes e bares e particularmente os cabarés de Pigalle, mas a esses ia com os ambas ou a malta da embaixada de Angola, deixava a família no hotel. (PEPETELA, 2008, p. 289).

Ante essa construção, o narrador aproveita alguns momentos para se aproximar um pouco do núcleo Caposso, e as personagens centrais desse núcleo são também retratadas a partir da ambição que possuem, como Mireille "a consumidora de arte" e Karim "o insaciável". Assim sendo, temos que além da hostilidade com Caposso, o narrador também se apresenta hostil com relação aqueles com quem Vladimiro possui certa afinidade. A resultante dessa equação é um narrador que reverbera ironia, acertando seu compasso com a voz hostil do próprio Caposso, apresentando, desse modo, um mundo que condiz à realidade desse tipo de ascensão social que busca, contundentemente, afastar-se (negando) do lugar de origem, como podemos verificar no trecho em que revela a "nova" Bebiana: "tinha vergonha de ter aprendido sem querer algumas palavras de kimbundo, quando era criança e morava num quase-musseque." (PEPETELA, 2008, p. 201).

Há, no entanto, na aguçada voz irônica do narrador, um breve indício, no capítulo 8 (1998), de que a realidade de Caposso começa a sofrer algumas (mesmo que ponderadas) adversidades. Seus mandos são questionados por novas personagens no cenário angolano, como o inspetor Celso Cardoso que desafia sua autoridade "mas deve ser um inspetor destes novos, todos cheios de boa vontade e excessivos no zelo" (PEPETELA, 2008, p. 207). Ainda que sua força destruidora continue muito elevada e, por isso, o tom irônico do narrador esteja devidamente evidenciado, esse capítulo, vindo de uma digressão de 2004 que apresenta uma ironia silenciada pela presença de Sebastião Lopes, como veremos a seguir, aponta para uma possível queda do protagonista. Queda essa que vai se perpetuar nos capítulos que correspondem à década de 2000 . 
Finalmente, o bloco dos quatro anos correspondente à década de 2000 abarca sete capítulos: 7 (2004), 10 (2003), 15 (2001), 16, 17, 18 e 20 (2004). Como apontado a partir de 1998, a derrocada do protagonista iniciada vai a cabo. Vladimiro, nesses anos de 2000, perde dinheiro e perde, consequentemente, poder, dentro da lógica do capital que se configura um pouco mais elaborada, excluindo, assim, a boçal postura de Caposso. Karim (O Insaciável) e Omar (O Cinzento), ficam com boa parte de sua fortuna, porque seu problema, como nos indica o narrador, "é que havia tubarões mais gordos ou mais fortes" (PEPETELA, 2008, p. 521).

Se no capítulo 15, abril de 2001, Vladimiro ainda aumenta os seus bens, com a casa de Huíla tocada por Ivan e a nova empreitada, uma construtora, e com relações políticas que lhe podiam angariar mais lucros financeiros, no jantar aos Ministros que inaugura a fazenda, é a partir do final desse mesmo capítulo que a sua situação começa a mudar. Irritado com o pai, Ivan é aconselhado por Gonga, o empregado da fazenda, a desobedecer a ordem e fazer de seu próprio jeito "tu fazer o que queres, sem ele se aperceber, e o contrário do que ele quer. Gozar calados sabe melhor" (PEPETELA, 2008, p 419). E então a derrocada de Vladimiro, timidamente anunciada nos final dos anos noventa, aqui toma proporções, aos poucos, mais graves.

Nos dois capítulos correspondentes a 2004, portanto, a queda acontece definitivamente e Vladimiro, ainda que muito longe de ser pobre, perde seu poder. Mas diante de um protagonista que insiste em manter a mesma impressão sobre seu próprio poder, recusando-se a enxergar a nova realidade que se apresenta ou, ainda, exergando apenas aquilo que lhe apetece, mas o narrador, mantendo a ironia, escancara a situação:

Mas o público não se deixou enganar pelo desmentido forçado, porque o mujimbo já tinha corrido antes explicando pelas ruas o desnorte de VC. A classe jornalística em particular se indignou com o comportamento rastejante e lambe-botas do diretor. E o sindicato dos jornalistas fez um comunicado defendendo o colega despedido e criticando o indigno diretor por se ter vendido de forma mais vergonhosa pela promessa de alguma publicidade. O jornalista despedido mereceu destaque nos outros jornais, com direito a entrevista em que ele reafirmava corajosamente tudo como se passara e nós, sem esperar pela controversa notícia, tivemos ocasião de conhecer direto. $\mathrm{O}$ dito jornalista aproveitou propalar aos quatro ventos que quando a imprensa se dobrava perante o poder econômico terminava a liberdade de expressão. Mas toda esta discussão deixou de interessar Caposso, satisfeito com as desculpas de verme produzidas no jornal. (PEPEPTELA, 2008, p. 431). 
Ao planificarmos essa análise através da linearidade convocada pela formação de blocos temporais, podemos verificar, na constituição da voz narrativa que acompanha Vladimiro Caposso, o adensamento do tom irônico. Isso ocorre graças a três elementos principais: o primeiro deles diz respeito à postura do protagonista. Arrogante e ambicioso, Caposso só enxerga em tudo a competição e sua ideia do outro se faz embalada nessa perspectiva, criando, assim, um exagerado desdém por todos aqueles que com ele estão a competir, traduzido em ironia. $\mathrm{O}$ narrador que o acompanha entoa a mesma característica, com uma singularidade: sua voz busca dissociar-se da voz de Vladimiro e, para tanto, não hesita em efetuar uma transfusão da carga irônica para a personagem. Tratando Vladimiro com ironia, o narrador ilumina a oposição que se dá entre os dois e que vai se ampliando gradualmente na medida em que Vladimiro alcança o poder: quanto mais poderoso fica, mais competitivo se torna, acentuando assim sua carga irônica; quanto mais irônico Vladimiro, mais irônico também o narrador que projeta a negatividade para a personagem: "Insensível à reprovação pública, o detentor do telemóvel atendeu e a sua voz de mija-grosso se ouviu, já disse que compro tudo(...)." (PEPETELA, 2008, p. 421). Podemos dizer, portanto, que narrador e Vladimiro Caposso encontram-se em posições antagônicas, que são impulsionadas principalmente pela caracterização da ironia de suas vozes.

Observando esse posicionamento contrário, temos que ao se aproximar de personagens como Nacib e Sebastião Lopes, e seus núcleos, o narrador executa uma ação contrária aos princípios que lhe vinham alicerçando a voz: silencia sua ironia.

\subsection{Ironia silenciada: a presença de Sebastião Lopes e Nacib}

Ao se aproximar de Vladimiro Caposso e seu núcleo o narrador adquire uma ironia que resulta numa crítica negativa e, por outro lado, o contrário se estabelece quando o mote do romance é o núcleo de Nacib e Sebastião Lopes.

O segundo capítulo da narrativa se postula, principalmente, pela quebra de atmosfera construída com a presença irascível do violento Vladimiro Caposso, ao se centrar no núcleo de Nacib, o menino do Catambor. O narrador, dessa maneira, constitui uma 
nova forma de apresentação que silencia a voz irônica, apontando, então, para uma disparidade entre Nacib e Vladimiro, assumindo certa cumplicidade com aqueles que fazem parte desse momento narrativo. Assim como cenograficamente Nacib faz o movimento contrário a Vladimiro tal qual o narrador nos apresenta: "Nacib ia fazendo o caminho ao contrário do movimento usado pela câmera na sequência anterior." (PEPETELA, 2008, p. 46), sua construção através da voz narrativa remete também para essa oposição, re-caracterizando a voz que narra. $O$ apagamento da ironia, principalmente quando o narrador lhe está próximo remete para outra postura narrativa também identificada em A geração da utopia, que denota certa cumplicidade. Para ilustrar essa diferença de posicionamento, a apresentação de Nacib é iniciada por uma temática oposta à apresentação de Caposso, à revelia do brutal assassinato que fecunda a construção deste, desenha-se outro tipo de cenário que evoca o inocente amor daquele:

Como vemos, naquele seu jeito de mulher pequenina, Nga Celestina adivinhava, embora não com precisão, a verdade, o infeliz amor de seu filho mais velho que, como lombriga no coração, lhe retirava toda a alegria. Amor por uma menina do Alvalade, bairro morando ao lado na realidade mais longe que as estrelas, menina rica de seu nome Mireille. (PEPETELA, 2008, p. 67).

E o clima de cumplicidade segue com sua apresentação de menino esforçado:

Nunca perdeu nenhum ano e estava sempre entre os melhores da sua escola. (...) Entrou no instituto no curso escolhido por ter muito boas notas, havia seleção chamada encaminhamento, também tinha de ter altas notas para entrar na universidade, mas aí era bem mais complicado, diziam. (...) Nacib havia constatado que no instituo aprendia quase apenas disciplinas teóricas, pois as oficinas e laboratórios estavam em mau estado e eram insuficientes para o número de alunos (...). Por isso foi falar com Sô Mateus, dono de uma oficina minúscula ali no bairro em baixo de uma árvore, pedindo lhe deixasse adquirir experiência com ele. (PEPETELA, 2008, p. 53-54).

Essa quebra de postura narrativa aponta para a presença de outros valores que não coincidem com os de Caposso. Enquanto a ironia hostil remetida a Vladimiro apresenta o seu caráter negativo, na busca desenfreada por ampliar seu capital, a cumplicidade para com Nacib aponta, por sua vez, para o seu caráter positivo, fecundando assim o universo dos opostos reificado pela posição do narrador, que, dessa maneira, institui os valores, ou a ideologia, a qual está vinculado.

Essa anuência entre narrador e personagem ocorre não somente com Nacib, mas também com Sebastião Lopes. Sebastião vai aportar na narrativa como o segundo 
oposto de Vladimiro: o caminho dos então amigos se dissocia a partir da independência do país e enquanto em Vladimiro vai se construindo a imagem do empresário predador, cuja ambição não encontra limites, o contrário ocorre com Sebastião, o advogado e intelectual que direciona o seu trabalho e sua vida para a construção de uma sociedade mais justa.

Próximo a Sebastião Lopes, o narrador também perde a tomada irônica, que direciona para a realidade que cerca a personagem, e não para a personagem, iluminando assim a honestidade para com o projeto de uma sociedade diferente dessa construída por Caposso e seus pares e mais próxima da proposta inicial vinculada à luta de independência, como podemos observar no trecho abaixo:

Foram soltos ao mesmo tempo e Chipengula voltou à sua Huíla natal. Trabalhou e estudou, acabando por se formar em História. Sebastião, entretanto, foi dificultado de emprego em emprego até se estabilizar numa empresa estatal que tratava de madeiras. E foi tentando inscrever-se em Direito. As primeiras tentativas foram infrutíferas, porque, embora as matrículas na universidade fossem na época livres e com pouca clientela, havia restrições para o novo curso de Direito, onde se forjaria a futura classe política, a qual devia ser coesa e de total confiança do governo. E ele tinha estado detido por inconfessáveis razões políticas. O pai dizia, é um pretexto para te queixares de injustiças, podes estudar outra coisa, mas ele queria esse curso, nenhum outro lhe interessava. Talvez por se ter distinguido na defesa de Luanda e depois na contraofensiva que expulsou o exército sul-africano e, em vez de algum reconhecimento, o terem detido. Foi preso por estar a distribuir panfletos subversivos aos soldados, panfletos que demonstravam a pouca consistência das promessas socialistas do MPLA e a necessidade de se formarem comitês clandestinos de militares para fazerem uma verdadeira revolução. Algum psicólogo mais matreiro poderia pois suspeitar que o seu interesse pelo Direito fosse para compreender o fundamento legal do que lhe tinha acontecido. Mas não, ele era mesmo um homem de causas. À terceira tentativa conseguiu entrar. Não sabe, foi segredo tão bem guardado quanto da conversa trágica entre Deus e o Diabo, mas a sua entrada na faculdade se deveu a insistência do pai (...). (PEPETELA, 2008, p. 183-184).

Essas duas personagens que aparecem recorrentemente na narrativa e com as quais o narrador se aproxima de maneira cúmplice, parecendo assim compartilhar a visão de mundo, têm características muito parecidas que constitui as suas personalidades: Nacib e Sebastião são homens honestos com pouca ambição financeira. E nesse sentido, a cumplicidade do narrador acaba por estipular os valores imprescindíveis que estão presentes em ambos como aquilo que se esperava dos homens numa Angola livre da 
colonização. Diferente de Vladimiro, cuja ambição não tem limites, Nacib e Sebastião atingem uma sensibilidade somente possível àqueles que buscam valores maiores do que o dinheiro, segundo o que fica postulado pela posição do narrador. Ao explicitar esse contraste entre os dois tipos de atitude narrativa, o narrador aponta para sua contrariedade com relação a Vladimiro.

Se a ironia tem na voz do narrador, como instância última, a rejeição de Vladimiro, isso repercute em um significativo distanciamento entre narrador e personagem, entre autor implícito e protagonista, entre protagonista e leitor. O inverso disso acontece com a prospecção de cumplicidade na voz narrativa, e nesse sentido podemos dizer que há uma espécie de falência da ironia na voz sempre que esta apresenta as de Nacib e Sebastião. Portanto, se quando incidente, a voz irônica é carregada do espectro da negatividade, a falência da ironia cria aquilo que é positivo.

Para observarmos tal contraposição, observemos os trechos abaixo que revelam a reflexão de Vladimiro e Sebastião acerca do mesmo lugar, Huíla. Enquanto Vladimiro conversa com o filho:

- E este é o sítio mais bonito de toda a região. Costumo tomar banho aqui.

- É lindo - concordou o pai. - Mas não dava para aproveitar esta água? Fazer um lago? Ela perde-se toda lá para sul, é uma pena, um desperdício.

- Só com uma represa. Está a acabar a época das chuvas e ele ainda leva muita água. Depois vai tendo menos e em agosto está quase seco, só corre um fiozionho. Com uma represa, podemos aproveitar as águas dos meses de chuva e fazer um lago, um reservatório. Mas se fazemos a represa aqui, acabamos com a cascata, o que também é pena dar cabo desta maravilha.

- Deixa essas coisas de artes e belezas naturais para a Mireille, ela é que é a especialista - disse Caposso. - Temos de ser práticos masé e aproveitar tudo. Vou mandar aqui um engenheiro. Ele faz os cálculos. Tu depois tomas conta das obras. (PEPETELA, 2008, p. 395-396).

O fluxo de consciência de Sebastião é exposto pelo narrador:

Os velhos contemplavam os campos do alto do morro com um misto de ternura, se tratava da terra dos antepassados que não se olha sem emoção, e de tristeza. Não precisava de conhecer a língua para entender. Uma vastíssima terra maravilhosa, com o sol a provocar faísca de luz no quartzo róseo e na mica do granito, aves e bichos criando cânticos ao vento, perfumes evolando da terra seca e anunciando os cheiros fortes do solo quando a chuva canta no capim dos telhados. Sim, uma terra maravilhosa. Mas destinada à miséria. (PEPETELA, 2008, p. 192). 
A contrariedade dos dois posicionamentos revelam o teor negativo do primeiro e o positivo do segundo, como podemos observar. Esse tipo de contraposição ocorre com frequência na narrativa, apresentada em capítulos distintos. Mas além dessas duas personagens centrais que suscitam uma inversão de postura da voz narrativa, evocando certa positividade, há outras personagens que surgem vitimadas pelo processo de desigualdade imposto pela atuação de tipos como Vladimiro e que também afastam a ironia do narrador. É o caso, por exemplo, do ex-combatente Simão Kapiangala, cuja vida é balizada pela tragédia. Simão perde duas pernas e um braço numa explosão de mina em um treinamento de guerra e não recebe nenhum benefício do Estado, sendo posto na marginalidade. Ao narrar sua história, o narrador parece tomado por certa solidariedade:

Por vezes, alguém lembrava, Luanda deve ser uma cidade bonita, não pode apresentar lixo nas ruas. E vinham polícias militares, apanhavam-no e aos outros mutilados que proliferavam nas ruas da cidade, os levavam como lixo para umas barracas longe do centro onde davam rações de combate para comerem durante dois dias e depois os esqueciam para morrerem mais depressa. Os que tinham próteses ou só tinham perdido uma perna eram os primeiros a chegar de novo às ruas de Luanda. Simão, se enrolando para rebolar sobre o asfalto incandescente, demorava mais, muito mais, era sempre o último a chegar ao sítio do emprego, como dizia. Alguém imagina que uma pessoa se possa locomover tendo só um braço? (...) Finalmente Simão encontrou um sítio tranquilo onde passar a noite e não muito longe da rua onde gostava ir esmolar. Era o cemitério do Alto das Cruzes, o qual tinha um buraco no muro que dava para a rua lateral. Ao fim da tarde ia rebolando pelo chão até meter pelo antigo bairro do Cruzeiro e chegar à sua porta (...). Dormia dentro do jazigo da família Mendes Fernandes, como constava no frontispício, construído em 1882 (...) Dos falecidos apenas um vago cheiro restava, talvez uma suspeita de cheiro (...). Dormiu durante alguns anos no jazigo. Às vezes se deixava ficar na sua morbidez (...). Permanecia mesmo com a sua fome dentro do jazigo dias inteiros, como sepultado em vida. (PEPETELA, 2008, p. 235-238).

Não menos vítima de tal processo, surge o menino Kasseke que se torna grande amigo de Nacib. Amizade essa que conduz, mais uma vez, Nacib ao ambiente oposto ao de Vladimiro. Enquanto as relações de amizades deste nascem pelo viés do interesse financeiro, as daquele são construídas a partir de laços fecundados também pela solidariedade: 
Comprou o produto e ficou pela conversa. Soube então da proveniência do outro, dormindo e vendendo artigos de eletricidade ali mesmo na avenida Marien Ngouabi.

- Mas dormes aqui?

- Do outro lado. Estás a ver aquela grelha de ferro? Se levantas a grelha, tem um buraco, dizem é para a água da chuva escorrer até o rio Seco e depois para o mar. Do buraco sai um tubo bué grosso, vai passar em baixo daquele prédio. Durmo aí.

Nacib se condoeu. Sabia, tinha muitos meninos, até meninas, fugidos a guerra ou da miséria, vivendo nas ruas, dormindo onde calhava, geralmente nos passeios perto de prédios grandes, nalguns casos protegidos pelas colunas. Às vezes via uns saírem da rua ali na Marien Ngouabi, de buracos, julgava de esgotos.

(...)

Se criou assim uma amizade entre os dois. Um dia Nacib convidou o amigo a ir a casa dele, se queres podes tomar banho lá, temos água e uma casa de banho.

(...)

Claro, para Kasseke, aquela casa pobre de um musseque pobre era um palácio(...). (PEPETELA, 2008, p. 352; 354).

Nesse embate travado entre Sebastião, Nacib e Caposso, este é derrotado. Sebastião Lopes vence a causa dos pastores de Huíla contra Vladimiro, mas o ápice de sua vitória não é esse ato em si, mas os abalos que suas ações provocam no ex-amigo, chamando-o para algum tipo de autoconsciência:

VC tinha intuição para algumas cenas, se tratava de algum trabalho vital feito por Sebastião Lopes para aquela gente, provavelmente sem cobrar, e por isso estavam tão agradecidos. Sentiu alguma inveja. Há muitos anos ninguém lhe olhava daquela maneira, grata e humedecida, com respeito também. Logo atalhou, sim, Sebastião até podia ser popular e respeitado ali naquele bairro onde cresceu, mas nunca seria rico. (PEPETELA, 2008, p. 484).

E Sebastião sentencia o grande abismo que há entre os dois:

- Mudou realmente tudo, se quer saber. O senhor, de jovem ingênuo e esperto, embora nada generoso nem desinteressado, passou a ser um sobeta intratável, arrogante, montado num tesouro que muito dificilmente poderá provar se de proveniência honesta. Eu continuo com as minhas ideias, junto do povo de que os dois saímos. É tão simples de entender... (PEPETELA, 2008, p. 489).

O desfecho apresentado com Nacib aponta ainda para além dessa perspectiva narrativa que se renova a partir do contraste entre Vladimiro e Sebastião. Com Nacib, o dinheiro, foco da ambição do protagonista do romance, sofre um processo de ressignificação que coloca em cheque, definitivamente, os valores de Caposso. Se para 
Vladimiro, o dinheiro tem uma conotação que torna seu caráter negativo, para Nacib o capital irá tomar conotação positiva, ao ser usado para beneficiar a seu amigo Kasseke.

Sorriam, lágrimas nos olhos de Kasseke, o coração de Nacib batendo acelerado. A noite estava limpa havia muitas estrelas no céu. Ali, naquela alto do Catambor, se podia ver as estrelas apesar do clarão da cidade. De um lado havia o Prenda, do outro a Avenida Marien Ngouabi. Ficaram a sentir a noite na cidade fervilhante, carros frenéticos por todos os lados rumando para as casas com as últimas compras de natal. Era noite de natal, terceira noite de natal em paz. Não havia sons de tiros nem balas tracejantes riscando o céu, não havia conversas sobre guerra.

Nunca mais? (PEPETELA, 2008, p. 545).

A última instância do embate que se trava entre essas personagens é a posição do próprio narrador, que se distanciando de Vladimiro pela ironia, afasta também de si o leitor, e o inverso, aproximando-se de Nacib e Sebastião pela cumplicidade, aproximaos do leitor.

\subsection{A ironia sobreposta ao enredo: o diálogo autor implícito e leitor}

Ainda que, como tentamos apontar até aqui, a voz do narrador em terceira pessoa de Predadores estabeleça em suas relações com as personagens as perspectivas que as condicionam, somos convocados a pensar ao longo do romance a entidade narrativa que se constitui em primeira pessoa e que definiremos como autor implícito. Em sua atitude de autoridade, o autor, responsável por modular esse antagonismo narradorprotagonista, e não satisfeito em simular-se apenas nessa relação e na construção da obra sob sua responsabilidade, passa, ele próprio, a intrometer-se na narrativa, com marcações textuais específicas que reiteram seu posicionamento - ou, como preferimos outrora: sua visão de mundo. Vimos que esse autor se manifesta também em A geração da utopia, mas aqui sua explicitação toma proporções mais acentuadas, apontando para a relação antagônica que estabelece com Caposso. Se em A geração da utopia o autor implícito vincula seu narrador às personagens, sempre condicionando esse narrador à sua visão de mundo e a de seu protagonista herói, em Predadores ele próprio se dispõe 
a manipular as ordens propostas pela literatura, constituindo uma voz dissonante que acumula o texto de ironia, e precipita e impulsiona a desvinculação entre sua visão de mundo e a do protagonista anti-herói, criando, para tanto, um diálogo direto com o leitor. Uma vez que a ironia para se constituir depende da intepretação do interlocutor, na relação entre o "ironista e o interpretador"21, o autor implícito aqui presente joga, também para o leitor a responsabilidade da construção da própria história, chamando sua atenção ou apontando novas informações.

Tal qual o autor que entra no início de A geração da utopia para apresentar a recusa ao professor opressor que pretendia silencia-lo, incitando assim a narrativa para a negação daquele que o nega, aqui haverá uma manifestação evidente dessa entidade também baseada na negação, mas que passa a comentar a obra de uma maneira mais incisiva.

E ainda que tal atitude nos remeta à atitude do autor de $A$ geração da utopia por exceder os limites da narrativa aos quais está condenado o seu narrador, a incidência de sua presença denota no texto a necessidade de exacerbar ainda mais a ironia vigente, contando que não haverá erro na percepção de seus leitores. Para tanto, cede a ironia um lugar de destaque tanto na maneira como resolve sua narrativa, ou seja, na distribuição não linear de seus capítulos, quanto na explicitação de sua voz.

Evidenciando o caráter de Vladimiro logo nas primeiras linhas, colocando ao lado dele um narrador que abusa da ironia para narrar os fatos nos quais ele se envolve, apontando para uma perspectiva irônica do próprio ato de narrar (com o desafio ao leitor que espera que o escritor lhe seja condescendente), o autor implícito de Predadores tangencia na obra um viés de negação que denuncia suas intenções. Ao negar o protagonista, através do narrador irônico, ele aponta justamente para as qualidades que irá negar. Podemos pensar que Vladimiro Caposso se torna, através desse movimento irônico que alavanca a negação, uma espécie de caricatura do sujeito que se constitui como o exato inverso do que se esperava daqueles que passam a controlar o poder numa Angola independente.

\footnotetext{
21 "Os principais participantes do jogo da ironia são, é verdade, o interpretador e o ironista. O interpretador pode ser - ou não - o destinatário visado na elocução do ironista, mas ele ou ela (por definição) é aquele que atribui a ironia e então a interpreta: em outras palavras, aquele que decide se a elocução é irônica (ou não) e, então, qual o sentido irônico particular ela pode ter." (HUTCHEON, 2000, p. 28).
} 
Como vimos, ao aproximar seu narrador de Vladimiro, Sebastião e Nacib, o autor implícito impulsiona essa voz narrativa para para a negação ou afirmação porque parte de comportamento opostos com relação às personagens: estabelecendo assim através da intensidade da ironia a proximidade (Nacib, Sebastião) ou o distanciamento (Vladimiro) do narrador. Essa maneira bastante eficiente de rejeitar ou consentir com determinados valores presentes em suas personagens não é o suficiente para o autor que se manifesta em Predadores utilizando mais dois métodos que exageram esse posicionamento. Um primeiro que trataremos é a lógica não-linear criada dentro de sua narrativa que reverbera na atmosfera de negatividade que circunda Vladimiro Caposso. Toda narrativa será condicionada ao movimento da negação, e para tanto a organização capitular postulada no romance é fundamental.

Nessa lógica, a configuração que se dá é que a cada capítulo em que a personalidade de Vladimiro ganha nova nuance de negatividade, ocorre uma digressão ou uma progressão que acabam por contribuir para a exacerbação desse caráter negativo. Nos três primeiros capítulos, ocorridos em 1992, há o contraste com Nacib, como vimos na análise de construção da voz narrativa irônica próxima a Vladimiro. Ocorre então uma digressão para a década de 1970, e em três capítulos Vladimiro passa de ingênuo a pequeno-burguês, contratando mais uma vez com a apresentação de Nacib com a mesma idade. A progressão então transporta o cenário de Vladimiro cercando sua nova casa que herda do ex-patrão português, para 2004, quando Sebastião conhece, através de Chipengula, os problemas que a imensa propriedade de VC criaram para os criadores de gado da região de Huíla.

Voltamos então para o ano de 1998, quando Ivan atropela Simão Kapiangala, o mutilado de guerra, que confunde com um cão. Ao contrário da irresponsabilidade dos atos do filho de Caposso, no capítulo seguinte uma progressão a 2003 aponta para o sério Nacib que "cumpriu a promessa que fez a mãe, dona Celestina das Dores, e se formou engenharia” (PEPETELA, 2008, p. 267). A postura de Nacib é incontestável e exemplar, principalmente quando colocada em contraposiçõa às posturas de Ivan e Caposso, apresentadas pela digressão que ocorre no capítulo seguinte e que nos remete a trágica vida de Simão. A narrativa que se dá em torno da vida de Simão aponta, mais uma vez, para a gravidade da atitude de Ivan, e destacadamente, para a atitude de Caposso, cuja ambição colabora para a desgraçada vida dos mutilados de guerra. Em 
mais uma digressão, a relação de Nacib com Susan, de amizade e carinho é contrastada com o pouco caso de Vladimiro com relação às mulheres que o cercam (ali, Bebiana e Manuela).

Há nova digressão e o capítulo apresenta derrocada dos escrúpulos de Caposso que aceita acusar um inocente de traição em troca de um cargo no comitê central, enquanto ambiciona tornar-se grande burguês. No capítulo seguinte, com uma pequena progressão de cinco anos, é narrada o início da amizade de Nacib e Kasseke, mais que isso, é exposto a grande miséria que atinge Kasseke e seu amigo Manuel e a solidariedade de Nacib e sua família. Outra progressão temporal são apresentadas nos três capítulos que se seguem: temos então Vladimiro com fome de dinheiro iniciando sua amizade com Karim, o estrangeiro que procurava se estabelecer no mercado angolano; a seguir a inauguração de sua casa na fazenda de Húla, mais um episódio de sua ambição, quando bem se relacionava com os ministros do governo e disso tirava grande vantagem; o afastamento de Karim por sua inadimplência e sua derrocada como empresário num universo que começa a ser dominado por novos interesses do capital.

Enquanto o capítulo 18 apresenta a mudança de Kasseke para o "palácio" de Nacib no Catambor, o 19 tem uma digressão até 1986 para relatar como Vladimiro de maneira brutal, através de graves ameaças anônimas e perseguição, consegue sua casa no Alvalade. Por fim, enquanto Caposso se percebe ficando sozinho e cada vez mais isolado, até mesmo pelos filhos, o momento final do romance mostra na amizade de Nacib e Kasseke a esperança que o dinheiro em novas mãos possa render frutos melhores.

Como podemos perceber, a não-linearidade que organiza o enredo acaba por determinar a personalidade de Vladimiro através do contraste com outras personalidades como Nacib e Sebastião Lopes e, ainda, que não tivéssemos o tom irônico do narrador tão latente quando próximo a ele, essa organização narrativa remeteria para a negação do caráter de Caposso.

O ponto de vista do narrador e do autor implícito é projetado na obra, portanto, através da negação e dois fatores apontam para isso, como vimos até agora: 1. a ironia; 2. a organização do enredo. Há, no entanto, um terceiro fator que marcará definitivamente o ponto de vista da voz narrativa: a explicitação do autor implícito. Em 
A geração da utopia percebemos um momento da explicitação da voz do autor implícito no início do enredo, cuja função parece ser projetar a obra para aquilo que nega: o outro opressor. Nessa rápida enunciação, o autor promete se retirar de cena, mas suas ações ao construir a própria obra acabam por delatar sua voz e sua visão de mundo.

O autor implícito de Predadores por sua vez, inverte essa ordem tímida e, ao longo da narrativa, apresenta-se muitas vezes, sempre que julga necessária sua intervenção, apontando para aquilo que lhe incomoda. E o que de fato parece lhe incomoda é uma possível falta de percepção do leitor para o que está sendo narrado. Nesse sentido, seus comentários são sempre eles próprios repletos de ironia e um tanto quanto jocosos, desafiando o leitor à atenção. Essa anunciação narrativa, que não caberia na voz do narrador, limitado que está aos fatos narrados (ainda que se dirija ao leitor por vezes) esboça-se abrindo a história (ficcional) para a História (de Angola), por vezes, mas principalmente abre a história à própria história. E nesse movimento o que entra em vigor mais uma vez é a hipótese da negação: se o romance caminha no sentido de negar aquilo que está estabelecido, qual seja o ato predatório dos empresários famintos por dinheiro e poder como Caposso, o autor implícito se posiciona também para o advento da negação. Nega as possíveis expectativas do leitor:

Curiosos, os leitores estão ansiosos por uma descrição da ementa e do que comeu o nosso parzinho. Desiludam-se, aqui não entra publicidade de borla. (PEPETELA, 2008, p. 92).

Nega algumas das "regras" literárias, ironizando a verossimilhança ou a economia literária:

Pois é, por ser exagerado demais é que ponho esta coincidência aqui, adoro inverosimilhanças, impossibilidades, arriscar ser chamado de excessivo, incapaz de medir consequências e mesmo, o pior de tudo num escritor, desleixado. Nem imaginam como me reconfortam as vossas críticas e maledicências... Por outro lado, escolher um terceiro americano para interferir mais tarde na vida de Caposso, criar-lhe uma voz e um rosto, além de um passado, me parece ser demasiado dispendioso, contrário à conhecida teoria da economia literária, sobretudo neste século de ideologia dominada pelo Fundo Monetário Internacional. Que o diabo decida entre as duas possibilidades. (PEPETELA, 2008, p. 276).

Se esperavam ler de mim que "tinham finalmente mostrado as mãos sujas", desenganem-se, não caio nessa inverossimilhança, Caposso nunca leu Sartre, até pode pensar que é alguma marca de água mineral. (PEPETELA, 2008, p. 490). 
Nega, por fim, os caminhos da História ou da realidade presente:

Se houver ocasião, talvez mais tarde se trate dessas árduas e estéreis questões econômicas, com fortes conotações políticas. (PEPETELA, 2008, p. 62).

O tal congresso que ficaria na História como o mais ortodoxo de todos os realizados e o culminar das guerrilhas internas para a absoluta centralização da autoridade. Alguns analistas mais ousados dataram daqui o surgimento em pleno dia da até então semi-escondida seita religiosa no interior do partido, com todo ritual desenhado para o culto litúrgico do chefe, enquanto alguns frustrados chegaram a chama-lo de congresso-da-usurpação-do-poder. (PEPETELA, 2008, p. 339).

E, simultaneamente, afirma a sua autoridade ao apresentar informações que se sobrepõem a capacidade narrativa do seu narrador em terceira pessoa. A negação e a voz de autoridade são características fundamentais na constituição dessa voz em primeira pessoa realizada pelo autor implícito é esse seu caráter de recusa e autoridade que ilumina por fim a completa dissociação entre os pontos de vista da voz que narra e o protagonista do enredo.

Sendo assim, o autor implícito aparece como a entidade que irá corresponder àquele posicionamento do espelho balizador já presente em A geração através do protagonista Aníbal. Lá, o herói da história acaba por se projetar como voz refletora das ações alheias: se lhes são compatíveis (Sara), aproximam o narrador, se lhes são antagônicas (Vítor e, principalmente, Malongo), acabam por distanciá-lo. A ausência de um herói como protagonista em Predadores parece determinar a maior insistência de autor implícito em se fazer presente como voz de autoridade. Se em A geração da utopia a prospecção de Aníbal (Sábio) coloca em cheque os valores que vão tomando espaço numa Angola independente que vai se degradando, em Predadores, cujo cenário inicial já está degradado pela presença de brutais predadores empresários, é o próprio autor implícito quem deve se manifestar para se contrapor ao seu protagonista: se Vladimiro tem poder nesse cenário degradado, o autor implícito apresenta, em contraposição, o poder da construção narrativa que colocará os seus valores em cheque.

A característica fundamental que determina o ponto de vista do qual é narrada a história, é, portanto, a ironia. Comungando ou não da intensidade irônica, autor implícito e narrador acabam por apontar para as personagens com as quais tem 
afinidade e com as quais não tem. Não seria imprudente afirmar que, sendo assim, autor implícito e narrador rejeitam o caráter de Vladimiro Caposso fazendo esse emergir na narrativa a partir e para a negatividade. Representando aqueles que contribuíram para transformar o país num abismo de classes sociais, Vladimiro, que veio do povo, dele se separa assumindo um posto social só conseguido através de sua ganância e falta de escrúpulos. Ao contrário disso, Nacib e Sebastião são apresentados pelo romance a partir de seus posicionamentos que implicam, principalmente, na presença da solidariedade, angariando os valores fundamentais daqueles que participaram da luta de independência do país: a construção de uma sociedade mais justa. Se a voz que narra recusa Vladimiro, distanciando-se através da ironia, com Sebastião e Nacib ela se aproxima, numa atitude de certa cumplicidade, como vimos.

O movimento de aproximação ou distanciamento já estava presente em A geração da utopia e, portanto, podemos afirmar que é uma elaboração que se repete em Predadores. Há, no entanto, uma singularidade entre essas vozes: se na primeira o narrador oscila entre o positivo e o negativo, e parece perplexo diante da realidade que vai apresentando, no segundo há um narrador que não vacila em entregar, ironicamente, aquilo com o que não concorda, aquilo que critica. Nesse processo particular de cada uma das vozes, podemos admitir a presença do elemento histórico, ou externo, como parte integrante da obra, configurada a partir da ideologia do autor implícito, conforme pretendemos apresentar no próximo capítulo.

\section{NO CERNE DA COMPARAÇÃO: APORTE TEÓRICO PARA ANÁLISE COMPARADA DOS ROMANCES}

\subsection{As vozes que contam: posição do narrador e presença do autor implícito}

(...) o homem no romance é essencialmente o homem que fala; o romance necessita de falantes que lhe tragam seu discurso original, sua linguagem. (BAKHTIN, 1998, p. 134). 
Para situar nossa análise no âmbito do foco narrativo, torna-se necessário levantar alguns pontos relevantes sobre esse elemento da estrutura narrativa. Muito embora sua importância seja senso comum entre os estudiosos e teóricos da literatura, as pontuações sobre a voz que conta a história são extremamente variáveis. O foco narrativo é concebido, de maneira geral, como o responsável por auxiliar e conduzir o leitor pelo percurso da história, mas se na epopeia a autoridade do narrador era indiscutível, a partir do advento do romance a autoridade imputada a ele passa a ser questionada.

Para o teórico russo Mikhail Bakhtin o romance é essencialmente o homem que fala. Essa fala não está restrita ao narrador, como sabemos, mas é ele, assumindo a voz da primeira ou da terceira pessoa ${ }^{22}$, em geral, quem conduz boa parte de uma narrativa. Para continuarmos a questão do foco narrativo nas análises dos romances $A$ geração da utopia e Predadores, parece-nos prudente apresentar, ao menos, um breve panorama de alguns teóricos que se dedicaram a ponderar sobre o ponto de vista das narrativas e que foram fundamentais para o advento da teoria de Wayne Booth, cujo cerne é a distinção das entidades do narrador e do autor implícito e que tem sido o alicerce de nossa análise.

O romancista norte-americano Henry James foi um dos precursores da discussão sobre a importância do ponto de vista na construção da narrativa. Para James, a única justificativa para a existência do romance seria sua tentativa de representar a vida e ter sentido para as pessoas assim como a vida o é; para tanto, deve ser revestido de "ar de realidade (a solidez da especificação)" (JAMES, 1995, p. 31) ${ }^{23}$. Muito embora se opusesse a imposição de limites formais à criação artística, James apontava para a necessidade do romancista em escrever a partir de suas experiências (momentânea ou duradoura) que seriam convertidas em histórias. Baseado nesse pressuposto de ilusão realista, James passa a explorar as concepções acerca do ponto de vista. Para respeitar sua percepção da necessidade da realidade, James defende um ponto de vista restrito a uma espécie de mente refletora. Essa mente, no entanto, não seria nunca a do próprio narrador senão de uma personagem com acentuado "nível de consciência". Os acontecimentos seriam narrados ao leitor, portanto, por intermédio objetivamente de um narrador em terceira pessoa a quem caberia eleger e refletir tais acontecimentos a partir

\footnotetext{
${ }^{22}$ São raros os casos de prosa realizada em segunda pessoa, conforme nos alerta Wolfgang Kayser e a nossa própria experiência de leitura.

${ }^{23}$ JAMES, Henry. A arte da ficção. São Paulo: Editora Imaginário, 1995.
} 
de uma perspectiva e de uma escolha definidas também sob o ponto de vista ou a mente de uma das personagens. A possibilidade de contato entre essa mente e o leitor seria responsável pelo tom "realista" do romance.

No prefácio de What Maisie Knew (Pelos olhos de Maisie), James justifica suas escolhas pelo ponto de vista da menina Maisie, ao mesmo tempo em que adverte para os limites da intervenção do narrador em terceira pessoa, expondo, assim, a partir da explanação sobre sua própria criação, sua perspectiva literária.

\begin{abstract}
Mesmo na melhor das hipóteses, a visão infantil conteria grandes hiatos e vazios, de modo que por mais sistemática que fosse a superfície, faltaria clareza ao sentido. Eu teria de incluir também o que minha testemunha intrigada via, concreta e inevitavelmente, boa parte o qual ela ou não compreenderia ou entenderia de modo equivocado e desse modo, e apenas desse modo, minha tarefa poderia ser realizada a contento. Assim sendo, lancei-me à tarefa de apresentar tudo, toda a situação ao redor da criança, porém apenas por meio das ocasiões e conexões de sua proximidade e sua atenção; apenas as coisas tal como poderiam aparecer diante dela e interessá-la, tocá-la, afetá-la, bem ou mal, contribuindo para sua percepção ou prejudicando-a, de modo que nós, testemunhas como ela, menos presentes porém mais críticos que ela, nos sentíssemos em posse da totalidade da situação. (JAMES, 2010, p. 904).
\end{abstract}

A partir de Henry James, muito se foi discutido e apontado sobre o foco narrativo. Seus pressupostos realistas influenciaram críticos como o inglês Percy Lubbock. Assim como James, Lubbock defendeu a necessidade de um narrador em terceira pessoa e o uso técnico da dramatização para a construção da ilusão realista. O romance instigante seria, para eles, aquele que de melhor maneira apresentasse tal ilusão. Torna-se imprescindível ressaltar que até esse momento não havia uma separação clara entre autor e narrador; e ambos formavam uma mesma categoria literária, sendo que ora respondiam por narrador ora por autor. Tendo essa confluência como pressuposta, verifica-se facilmente a plausibilidade da consideração do romance em primeira pessoa pouco realista, pois que nesse tipo de abordagem fica evidente a dissociação entre o autor que escreve e o narrador que narra. Nas palavras de Lubbock:

Tenho cá para mim que toda a intricada questão do método, no ofício da ficção, é governada pelo problema do ponto de vista - o problema da relação que se estabelece entre o narrador e a história. (...) Se o próprio contador da história estiver $n a$ história, o autor será dramatizado; suas asserções ganharão peso, pois serão amparadas pela presença do narrador na cena descrita. É a vantagem que se tem; o autor transferiu sua responsabilidade, que agora está onde o leitor a 
pode ver e medir; a qualidade arbitrária que, a qualquer momento, se detecta na voz do autor, é disfarçada pela voz de seu representante. Nada se importa de fora para a história; independente, ela não tem associações com ninguém fora de seu círculo. (LUBBOCK, 1976, p. 155).

Essa dissociação entre autor e narrador foi feita com clareza pelo crítico alemão Wolfgang Kayser, que passa a considerar o narrador também como ser ficcional criado pelo autor, num processo em que "o autor oculta-se então atrás do narrador na boca do qual põe a narração" (1985, p. 211). A partir dessa nova perspectiva, a diferença entre uma narração feita em primeira pessoa ou em terceira se torna insignificante, uma vez que a técnica empregada à voz narrativa é escolhida "apenas" para responder as necessidades impostas pelo objetivo que se pretende alcançar na construção literária; e não se define como um limite técnico da construção da obra. Para Kayser, a obra literária deve ser analisada a partir de sua elaboração interna, e a qualidade da narrativa deverá ser julgada a partir da relação de causa efeito presente na obra.

Se para Kayser é fundamental que distingamos o narrador do autor, sendo aquele a criação deste, Wayne Booth foi além ao cunhar o termo autor implícito. Em comum com Kayser, Booth refuta a não diferenciação entre o autor e o narrador, ou seja, entre aquele que elabora a obra e aquele que é parte da obra, todavia ele faz uma distinção ainda maior ao apontar como duas entidades distintas o autor-homem e autor-implícito. Ao analisar as técnicas narrativas, Booth parte do pressuposto de que há um homem real na concepção da obra, o autor, e uma entidade que se impõe à obra e nela se revela, constituindo e manipulando os valores que lhe emanarão. A presença desse autorimplícito é verificável para além da posição do narrador; aliás, tal posição será ela própria fruto da imposição do autor implícito que dela faz uso para beneficiar a construção de sua literatura. O autor implícito surge, assim, como um alter ego do autor na obra; para Booth o autor apresenta seu alter ego ou uma versão de si em cada obra que produz.

Temos que falar em várias versões porque, independentemente da sinceridade que o autor intenta, cada uma das suas obras implicará diferentes versões, diferentes combinações ideais de normas. Tal como as cartas pessoais de cada um de nós implicam diferentes versões de nós próprios, dependendo das diferentes relações que temos com cada correspondente e da finalidade de cada carta, o escritor assume ares diferentes, dependendo das necessidades de cada obra. (BOOTH, 1980, p. 89). 
Se assumimos o conceito boothiano que determina uma diferença entre o autor implícito e o narrador para iluminar a análise da elaboração artística da voz narrativa em A geração da utopia e Predadores é porque essa diferenciação nos parece fundamental para refletir acerca da construção que Pepetela realiza nessas obras. Como ressaltamos durante as análises apresentadas, tanto A geração da utopia quanto Predadores apresentam a distinção dessas vozes que rementem para a ação narrativa, nela influenciando. $\mathrm{O}$ autor implícito, é importante frisarmos, desnuda sua própria voz na primeira timidamente e na segunda desabrocha com uma intensidade intromissiva, ressaltando seu papel no cotejo irônico que recai principalmente sobre o protagonista anti-herói do enredo. Nesse sentido, cabe-nos ressaltar a percepção do elemento externo, internalizado em obra, tornando-se parte estruturante da estética ${ }^{24}$ dessas obras de Pepetela. A presença mais ou menos peremptória desse autor implícito é determinada pelo contexto histórico nos quais as obras foram formuladas e que delas se tornam parte, reconhecendo-se nos limites emoldurados pela historicidade suas diretrizes: o componente histórico passa a ser elemento fundamental da estética pepeteliana à medida que alicerça as vozes narrativas dos romances. Dessa forma, queremos apontar para um fator fundamental de compreensão desses romances de Pepetela: o forjar do processo histórico angolano. Para prosseguirmos, portanto, com a análise comparada desses focos narrativos, torna-se necessário o reconhecimento de alguns dados relativos a esse processo que tem colaboração fulcral para a formação das vozes que narram.

\subsection{Vozes dissonantes: a consolidação das vozes enviesadas por eventos históricos}

Ainda que a reflexão acerca da história angolana exceda os limites desta dissertação, que se concentra na análise das vozes que narram dois romances de Pepetela, ao assumirmos que a obra do escritor é alavancada por uma produção que se volta para a história do país, temos, obrigatoriamente, para melhor embasarmos nossa análise, que

\footnotetext{
${ }^{24}$ No Prefácio de $O$ discurso e a cidade, o crítico Antonio Candido aborda o processo que denomina redução estrutural: "isto é, o processo por cujo intermédio a realidade do mundo e do ser se torna, na narrativa ficcional, componente de uma estrutura literária, permitindo que esta seja estudada em si mesma, como algo autônomo". (CANDIDO, 2004, p. 9).
} 
fazer um breve apontamento acerca dos eventos históricos que estão circunscritos na composição de A geração da utopia e Predadores. Se não caberia neste trabalho um levantamento detalhado de tais eventos, cabe-nos, ao menos, apresentar um apanhado geral dos episódios fundamentais da história angolana que aparecem particularmente internalizados nessa produção romanesca de Pepetela. Parece-nos, assim, que é a partir dessa confrontação com os processos históricos que fulguram nas obras que se estabelece a principal diferença entre seus narradores.

Em Angola, o movimento de libertação teve início deflagrado em 4 de fevereiro de $1961^{25}$, quando ocorreu o ataque às prisões de Luanda, para libertação de presos políticos, respondido violentamente por Portugal. No entanto, o país garantiu sua independência, oficialmente, apenas em 11 de novembro de 1975, após um extenso período de colonização (sobretudo aquele que se organiza a partir da Conferência de Berlim $^{26}$ ) e um ano de negociação com o governo português ${ }^{27}$. Os anos marcados pelo confronto bélico na sociedade angolana - da guerra de libertação ${ }^{28}$ (1961-1975) e, logo a seguir, da guerra civil (1976-2002), que eclodiu entre os diferentes movimentos, apoiados material e ideologicamente por dois grupos distintos e opostos, liderados pelos EUA e pela URSS -, confluíram para a formação do imaginário angolano. A guerra ${ }^{29}$, portanto, configura esse imaginário incidindo de duas maneiras: fazendo parte da utopia, no momento inicial (principalmente a guerra de libertação), e esgarçando essa mesma utopia, no momento seguinte (principalmente nos longos anos de guerra civil,

\footnotetext{
${ }^{25}$ Embora o 4 de fevereiro remeta à ação do resgate de presos em Luanda, reivindicada pelo MPLA, e o 15 de março a revolta ocorrida no Norte, precipitada pela UPA, BITTENCOURT enfatiza "o ganho político" que a revolta dos camponeses na Baixa do Cassanje, entre dezembro de 1960 e janeiro de 1961, proporcionou ao MPLA e a UPA, e, consequentemente, a luta anticolonial, (2008, p. 75). Sobre isso, aponta Leila Hernandez: "Paralelamente, estouravam rebeliões que atingiram uma escala substancial e, em todos os casos, implicavam queixas econômicas dos trabalhadores agrícolas. Destas, a principal foi a de Baixa de Cassanje, de 1960 a 1961, que contestava as condições de trabalho próprias do domínio colonial, desafiando, sobretudo, o cultivo obrigatório de algodão implantado havia mais de trinta anos, além de acabar com bens e propriedades de brancos e mestiços." (HERNANDEZ, 2008, p. 576)

${ }^{26}$ Conferência de Berlim - 25 de novembro de 1884 e 16 de fevereiro de 1885.

${ }^{27}$ As negociações se precipitam a partir da Revolução dos Cravos, que culmina no fim do regime salazarista em abril de 1974, resultando no cessar-fogo em novembro desse mesmo ano.

${ }^{28}$ Os portugueses chamariam de Guerra Colonial, no entanto, optaremos por Guerra de Libertação, conforme a concepção angolana.

${ }^{29}$ É importante frisarmos, como bem nos alerta Laura Padilha (CHAVES, MACEDO, VECCHIA, 2007, p. 55) que pontuamos aqui esse período da guerra sem, no entanto, deixarmos de atentar para a violenta colonização a qual Portugal submete Angola, que resulta em diversas revoltas e batalhas anteriores ao período recortado. Segundo Marco Antonio Liberatti, "a ocupação portuguesa em Angola foi um processo lento e difícil (...) que custou à coroa o sacrifício de envolver-se em inúmeras guerras com os povos locais", e mesmo quando Portugal passou a ocupar a colônia, isso nunca significou a "desejada e definitiva pacificação de Angola pela metrópole." (LIBERATTI, 1999, p. 8).
} 
com poucos e curtos períodos de intervalo). Portanto, surge ora representada positivamente, como salvaguarda do nascimento do país livre (durante o período de luta de libertação) ora negativamente, como consequência danosa de interesses políticos de grupos distintos (na Angola independente).

A despeito da difícil realidade em Angola nesses longos anos de guerra colonial, fazia-se extremamente necessário que a história fosse apresentada por outras vozes que não a do colonizador. Perante esse quadro, encontramos na base da formação literária angolana o compromisso com a luta, voltando-se o escritor no âmbito literário para esse compromisso, com o desejo de, através da prosa ou poesia, (re)contar a história do país por tanto tempo oprimido pelo colonialismo, e registrar a história presente, apontando as dificuldades e possibilidades para os caminhos futuros. Se o nascer da luta de libertação assegurava o processo de ruptura político-cultural com a estabelecida opressão portuguesa, a literatura irá apresentar um projeto ideológico no plano artístico ligado à formação de nação e à resistência. $\mathrm{O}$ fortalecimento da voz nacionalista no contexto literário se intensifica a partir de 1948, com o movimento "Vamos descobrir Angola". Sobre isso, pontua Rita Chaves:

Esse caráter de urgência de que se vai revestindo a vida gerada no interior do sistema colonial abre possibilidades para a construção de um patrimônio cultural onde não seria minimizada a dimensão de resistência como linha condutora do processo. (CHAVES, 1999, p. $32)$.

Nesse contexto de guerra que ocorre a partir dos anos de 1960, do qual a "literatura não poderia ficar protegida" 30 , a perspectiva militante dos autores engajados torna-se explícita, embora seus projetos artísticos apresentem singularidades. A guerra passa então a ser um tema recorrente na literatura do país e será retratada pelos escritores com o lirismo que aponta para uma dimensão épica, no primeiro momento de guerra colonial, e com certa desconfiança que desperta a crítica, a partir do início da guerra civil.

Pepetela não escapa a esse movimento que direcionava as produções artísticas dos escritores que surgem à época, e seu projeto literário insurge nessa expectativa da literatura como forma de luta, compromissada com a formação do Estado-Nação, e reflete o percurso da guerra e das possibilidades advindas desse contexto, a partir de

\footnotetext{
${ }^{30}$ CHAVES, Rita. A formação do romance angolano. São Paulo: Via Atlântica, 1999, p. 50.
} 
certo vínculo com a perspectiva do MPLA $^{31}$, movimento ao qual ele esteve por muito tempo ligado. Permeados pelo ponto de vista histórico, os textos de Pepetela imprimem na ficção fatos dos quais ele próprio é testemunha. Esse tipo de criação literária poderia também ser aproximada a uma perspectiva de literatura testemunhal, ou seja, aquela que tem como foco um acontecimento traumático, resultante de mudanças históricas, políticas ou sociais, que em geral ocorrem de maneira violenta.

Marcio Seligmann-Silva, em História, memória, literatura, coloca-nos que uma literatura de testemunho se manifesta por vezes pela necessidade de se lidar com uma situação-limite; apoiando-se na própria memória: “Aquele que se recorda deve poder percorrer essas paisagens mnemônicas descortinando as ideias por detrás das imagens" (SELIGMANN-SILVA, 2006, p. 56), o escritor expressa fatos da realidade "atenuados" por recursos estéticos (a "busca da voz correta" p. 57), que tornam essa realidade violenta verossímil perante aqueles que não a presenciaram. Ainda que o processo desencadeado pela guerra de libertação tenha especificidades que a distanciam do modo como na Segunda Guerra Mundial foi desencadeado e deflagrado violentamente o holocausto, consideramos e partimos do ponto de vista da guerra de libertação que impôs aos seus combatentes a necessidade imperiosa de partir militarmente para o confronto contra Portugal, e isso, sem dúvida, não pode deixar de ser considerado como uma ruptura que impõe a violência como cerne da questão. Sobreviver e emancipar o país eram as duas palavras-chave do movimento para as quais Pepetela estava naquela altura absolutamente engajado.

Para além da realidade violenta, o escritor denuncia e delata fatos e ainda que a guerra esteja presente e tenha graves consequências na sociedade que se vai configurando, os eventos traumáticos vividos em Angola excedem os limites da guerra, para contextualizarem-se na constituição do país independente em formação, isso porque entre o projeto de emancipação com tendências socialistas presentes na base de formação do MPLA e o que de fato se concretizou na política angolana desponta um abismo de divergências que também (senão ainda mais enfaticamente) causam traumas

\footnotetext{
${ }^{31}$ Movimento Popular de Libertação de Angola, segundo Leila Hernandez, "De acordo com a versão oficial do MPLA, este partido foi fundado em 10 de dezembro de 1956 e resultava da junção do Plua com outros militantes fundadores do PC de Angola. Nesse momento destacaram-se Mário Pinto de Andrade, Agostinho Neto e Viriato da Cruz, que professavam uma "ideologia marxista"”. (HERNANDEZ, 2008, p. 574)
} 
naqueles cuja formação política e disposição para a luta foram transpassadas por essas primeiras diretrizes do Movimento.

Inserido nesse grupo, Pepetela não se exime do desconsolo que toma conta desses homens compromissados com tal projeto político, e podemos dizer que sua reflexão acerca do processo histórico do país encaminha em sua obra a discussão dessa fratura do projeto idealizado. Sendo assim, ainda que a guerra permeie A geração da utopia e Predadores $^{32}$ como pano de fundo, (a guerra de libertação e mais tarde a guerra civil), os romances revelam um cenário degradado mediante a violência e a miséria consequentes da guerra e apresentam, como leitmotiv, um repertório que aponta para o pós-guerra de libertação, focando com alguma intensidade nova estratificação social ${ }^{33}$ que se desencadeia no país no pós-independência, durante o governo do MPLA, e que não condiz com o projeto embrionário de uma Revolução que proporcionasse maior igualdade social ou sua concreta emancipação social.

Acreditamos que essa preocupação com a convergência entre produção artística e reflexão acerca dos processos históricos marca definitivamente alguns aspectos estéticos da literatura pepeteliana. E, sendo assim, a circunscrição temporal presente em cada uma das obras torna possível que verifiquemos dissonâncias nas vozes narrativas (narradores e autores implícitos) que as compõem, aportadas na delimitação do tempo apresentado em cada uma delas. Assim, temos que enquanto em A geração da utopia há um forte indício de positividade em seu início, angariado pela voz do narrador que acompanha Sara e Aníbal, pelo contrário, em Predadores a voz narrativa (tanto do narrador quanto do autor implícito) sofre um acúmulo de negatividade disparada pelo recorrente uso da ironia, como pudemos observar na análise. Essa diferente estruturação inicial, que repercute no desenvolvimento dessas vozes ao longo dos romances, ocorre, ao que nos parece, porque o elemento histórico presente na obra acaba por ser refletido

\footnotetext{
${ }^{32}$ Notemos ainda que a guerra é tema de importância central para outras produções do autor, como Mayombe, na qual é vista a partir da perspectiva de personagens guerrilheiros, que apontam para um adensamento utópico, e é pano de fundo mas com aspecto central em Parábola do Cágado Velho, onde representa o esgarçamento da utopia, acabando por separar a família (núcleo) protagonista do enredo.

${ }^{33}$ Consideramos que o colonialismo proporcionava a estratificação social tendo em vista que além da divisão social entre colonos e colonizados, pequenos espaçamentos sociais eram abertos (e apenas à medida que interessava ao próprio colonialismo) nos quais adensavam assimilados. Essa divisão social, da qual trata Frantz Fanon, em Os condenados da terra (França, $1^{a}$ ed. 1961, no Brasil, 2006, Editora da Universidade Federal de Minas Gerais) e Albert Memmi em Retrato do colonizado precedido pelo retrato do colonizador (1967, Editora Paz e Terra), é diferente do que passa a ocorrer após a independência, com a saída do colonizador, quando começa a se formar uma burguesia local.
} 
no comportamento dessas entidades narrativas. Nesse sentido, para o desenvolvimento desse mapeamento dos narradores e autores implícitos presentes nessas duas obras pepetelianas torna-se importante que atentemos para alguns episódios históricos ocorrido em Angola que coincidem com as alocações temporais das narrativas e que acabam por corroborar com a diferente perspectiva elaborada em seus focos narrativos.

A composição inicial de $A$ geração sobrecarrega o narrador de um viés utópico e está embebida na positividade do ano que inicia a narrativa, conforme já buscamos apresentar anteriormente. Em 1961, com o advento da luta de libertação, todas as expectativas com relação à formação de uma nova nação livre do inimigo colonial fomentavam no imaginário daqueles que da luta participavam a utopia capaz de fortalecer o movimento. O autor implícito, ao aproximar seu narrador de Sara aponta exatamente para esse sentido e a apresentação de Aníbal como homem ideal que se compõe como uma espécie de balizador entre aspectos positivos ou negativos de outras personagens colabora com essa percepção; o autor implícito ainda, autonomamente, incita na narração a tomada de consciência e a negação do outro (colonialista) opressor. Tanto narrador quanto autor implícito, nesse momento da narrativa, possuem como característica fundamental uma voz crítica configurada no comentário que os torna narradores participativos, com certa força analítica diante daquilo que narram.

Se ao longo da narrativa vão, aos poucos, perdendo essa característica, é no final, com o ano que encerra a narrativa mergulhado na decomposição desse cenário motivador que podemos identificar uma sensível mudança na caracterização dessas vozes. Em 1992, com o intervalo da guerra civil, emerge na narrativa figuras como Malongo que parecem inseridas na classe que Frantz Fanon chamou de burguesia subdesenvolvida.

\footnotetext{
A burguesia nacional que toma o poder no fim do regime colonial é uma burguesia subdesenvolvida. Seu poder econômico é quase nulo, e, de qualquer forma, sem medida comum com o da burguesia metropolitana, que ela pretende substituir. (...) No seio dessa burguesia nacional dos países subdesenvolvidos não se encontram nem indústrias nem financistas. A burguesia nacional dos países subdesenvolvidos não se orientou para a produção, para a invenção, para a construção, para o trabalho. Canalizou-se inteiramente para atividades de tipo intermediário. "Ser esperto", "estar por dentro", essa parece ser a sua vocação profunda. A burguesia nacional tem uma psicologia de homem de negócios, não de capitão de indústria. É verdade que a rapacidade dos colonos e o sistema de embargo
} 
instalado pelo colonialismo não lhe deixaram escolha. (FANON, 2010, p. 176-177).

Sobre a relação dessa elite com o colonialismo, orienta-nos ainda os apontamentos de Kabengele Munanga:

(...) as elites de quem se fala tão mal desorientadas pelos sonhos nascidos na Europa e que querem desesperadamente retomar o lugar do antigo colonizador, para esquecer os séculos de humilhação e recuperar sua identidade. (in REVISTA USP, 1993, p. 102).

Acompanhando o desenvolvimento do que parece ser essa burguesia representada, principalmente, por Vítor e Malongo, em A geração, a voz do narrador se torna cada vez menos audível diante dos diálogos que se estabelecem com intensidade e que a ela se sobrepõem, e o autor implícito o abandona nesse silenciamento, projetando assim uma espécie de perplexidade que só será suplantada, ainda que muito timidamente, no último dos epílogos do romance. Essa nova condição nos faz imaginar que a perplexidade diante dos fatos que narra tomou de tal modo o narrador que sua voz perde forças, aquiescendo à realidade que observa. Sua força analítica, portanto, encontrava-se presente enquanto o projeto caminhava voltado para ultrapassar as forças do colonizador, inimigo comum a todos angolanos. A partir do momento em que o projeto começa a apresentar as fissuras evidenciadas pela emergência dessa "burguesia" que se cola ao Estado para dele tirar benefícios particulares, o narrador torna-se atônito e, logo, incapaz de manter a voz crítica. Parece, portanto, deslocado para um tempo no qual sua sagacidade crítica e participativa, tal qual se apresenta no início do romance, é aniquilada.

Predadores, por sua vez, tem como ponto de partida o mesmo ano que finda $A$ geração, 1992, com um narrador que inicia sua apresentação através da observação da ação de Vladimiro Caposso, mas que, aos poucos, vai tomando certa intensidade irônica, ou seja, a característica que o qualifica não é estar perplexo diante do que narra, mas o inverso, aplicar uma crítica incisiva aos fatos narrados. Temos então um diferenciação temporal significativa entre os romances que age sobre seus focos narrativos: enquanto uma é iniciada pela fulguração da efervescência utópica da romântica época de início de luta de libertação que marca definitivamente a postura de seu narrador, a outra se inaugura por um narrador que observa e narra ações que ocorrem em um Estado maculado por uma expandida desigualdade social, precipitada 
pela presença da "burguesia subdesenvolvida" consolidada na figura de seu protagonista.

O fator consubstancial para o processo artístico que compõe esses narradores e autores implícitos pende então para o processo histórico delineado nas obras que delimita suas vozes. Em 1992, Angola vinha de um processo bélico que superava três décadas: treze anos de guerra de libertação ${ }^{34}$ e dezesseis anos da guerra civil que se acontecia, principalmente ${ }^{35}$, entre MPLA (partido do Governo), e UNITA ${ }^{36}$. Nesse ano, havia já ocorrido uma grande dissociação entre a sociedade almejada durante a luta de libertação (tendendo para os ideais socialistas) e a realidade alcançada (a partir da formação da nação independente). Há, portanto, uma significativa diferença entre os ânimos formulados pelas novas configurações do cenário angolano. Enquanto na década de 1960 são fundamentadas as diretrizes da luta, com a movimentação que daria início a guerra de libertação e o fortalecimento do MPLA e das forças que lutavam contra Portugal, na década de 1990 a guerra se perpetuava, contribuindo radicalmente para as amplas dificuldades enfrentadas pelo país no pós-independência.

Apesar do otimismo presente em 1961 nos países que ainda sofriam com a colonização, o arraigado e necessário "apego" português para com as colônias acabou por prolongar a guerra, num exemplo contrário ao que vinha ocorrendo em outros países africanos $^{37}$. A resistência portuguesa resultou no aumento do cerceamento das necessidades básicas locais e a fome se alastrou a tal ponto que aldeias inteiras se realocavam em busca de lugares com maiores possibilidades de sobrevivência. No início da década de 1970, a situação dos combatentes também se apresentava bastante precária, com o aperto aos cercos realizados pelos portugueses, mas essa realidade sofreu uma reviravolta a partir 25 de abril de 1974, com a Revolução dos Cravos que derruba, por fim, a ditadura salazarista em Portugal. Uma das consequências da queda de Salazar foi uma negociação com as colônias (Portugal a essa época já havia

\footnotetext{
34 Não contabilizamos nessa somatória o período de novembro de 1974 a novembro de 1975, cujas negociações pré-independência estavam sendo realizadas com Portugal.

35 Em 1978, num acordo entre Agostinho Neto e Mobuto, as bases da FNLA são fechadas no Zaire. Holden Roberto segue então para o exílio em Paris. Sobre isso, sugerimos a leitura de LIBERATTI, 1999 p. 66).

${ }^{36}$ União Nacional para a Independência Total de Angola, que surgiu em 1966 liderada por Jonas Savimbi.

37 “(...) o governo português mostrava-se invulnerável quanto à negociação para uma transição pacífica, mesmo pressionado pela declaração sobre a concessão da independência aos países e povos coloniais, aprovada em 14 de dezembro de 1960." (HERNANDEZ, 2008, p. 576)
} 
designado muitas forças financeiras e humanas nas guerras que aconteciam em Angola, Moçambique e Guiné Bissau ${ }^{38}$ ), resultando no acordo do cessar fogo, em $1974^{39}$. As negociações com os portugueses perduraram, no entanto, até novembro de 1975, quando Agostinho Neto declara em Luanda a independência de Angola e torna-se o primeiro presidente da República ${ }^{40}$.

A partir das negociações do cessar-fogo, acirram-se ainda mais as divergências entre as três forças que participaram da luta de libertação e, portanto, quando finalmente ocorre a independência de Portugal, uma crise política entre MPLA, FNLA e UNITA, já estava estabelecida e contava com a intervenção de apoios internacionais ${ }^{41}$ que passam a munir a guerra civil de Angola através do fornecimento de armas, treinamento, dinheiro e homens.

Nem por isso a batalha estava encerrada. A internacionalização da guerra havia transformado, o que havia começado como uma guerra de guerrilha, com o uso de armas ligeiras, em uma guerra de grandes proporções com equipamento bélico pesado, que compreendia desde armas de manuseio manual, até blindados, artilharia aérea e antiaérea. Esta guerra ainda se estenderia por longos 30 anos, com seus principais líderes mudando seus discursos de acordo com as novas configurações mundiais. (ARAÚJO, 2005, p. 65).

Após a independência, o governo do MPLA encontra, portanto, sérias dificuldades internas $^{42}$ ao movimento e externas a ele, para estabilizar o Estado, desde questões relacionadas à infraestrutura, principalmente com o atraso econômico resultante do colonialismo, até a guerra civil ${ }^{43}$. Ainda que em 1976, o governo tenha conseguido se

\footnotetext{
${ }^{38}$ Segundo Liberatti, foram 11 mil mortos e 30 mil feridos. (1999, p. 41).

${ }^{39}$ Os três movimentos assinam o acordo em diferentes momentos, sendo a UNITA a primeira a assinar, em 14 de junho de 1974, seguida pela FNLA em 12 de outubro de 1974 e, finalmente, o MPLA em 21 de outubro do mesmo ano.

${ }^{40}$ Enquanto Agostinho Neto declarava a independência do país em Luanda, amparado por tropas cubanas que se encontravam na cidade, UNITA e FNLA o fazem em Huambo, então segunda maior cidade de Angola. Agostinho Neto permanece na presidência de Angola até setembro de 1979, quando falece em Moscou.

41 À época da Independência, o quadro de apoio estava desenhado da seguinte maneira: FNLA era apoiada pela China, o MPLA, por URSS e Cuba e a UNITA era apoiada pelos EUA e a seguir pela África do Sul. "Jonas Savimbi procurou estabelecer uma aliança entre seu movimento e o governo sul-africano regido pelo apartheid. Em 14 de outubro de 1973, entrava em Angola a maior força intervencionista sulafricana já organizada. A força combinada ainda contava com forte apoio aéreo." (LIBERATTI, 1999, p. 44).

${ }^{42}$ Nota-se que antes mesmo da Independência, rupturas internas já eram perceptíveis no MPLA, exemplo disso são a Revolta do Leste, liderada por Daniel Chipanda, a Revolta do Norte e a Revolta da Ativa. Sobre isso, recomendamos a leitura de Bittencourt e Araújo.

${ }^{43}$ Sobre isso, sugerimos a leitura de: BITTENCOURT (2004); RUIVO (2005); LIBERATTI (1999).
} 
fortalecer a ponto de anular brevemente as forças contrárias, suas vigorosas contradições internas refletiam nos posicionamentos do partido na década de 1980, como alerta Marina Ruivo:

Já na década de 1980, a distância entre teoria e prática foi ganhando consideráveis dimensões na sociedade angolana. Paralelamente ao discurso oficial, que continuava afirmando que Angola estava a caminho do socialismo, as críticas às incoerências entre palavras e atos manifestavam-se na sociedade, com o objetivo, em geral, de formular maneiras de resolvê-las e contorna-las, ou seja, insistindo na defesa da aplicação do projeto socialista. (RUIVO, 2005, p. 209).

A década de 1980 foi marcada ainda por intensos conflitos bélicos entre MPLA e UNITA. A UNITA se fortalece novamente apoiada pela África do Sul e pelos EUA (que havia se afastado na década 1970) e entre 1984 e 1987 realiza fortes ataques ao governo. Em 1981 e 1983, por exemplo, realiza seis grandes intervenções em Angola e anuncia o início da guerrilha urbana, em 1984. Em 1987, o presidente do país José Eduardo dos Santos (MPLA) pede ajuda a Fidel Castro, que envia homens para o auxílio do MPLA. E a guerra, conforme nos aponta Liberatti, atinge calamitosas proporções:

O conflito naquela parte de Angola passava a assumir aspectos de uma guerra moderna. Tratava-se, na verdade, da maior batalha convencional travada na África Austral. Em dezembro, 9 mil sulafricanos das forças regulares e 35 mil insurgentes da UNITA, apoiados por veículos blindados e artilharia de $155 \mathrm{~mm}$ de longo alcance começaram a atacar a cidade [de Cuito Cuanavale]. Nos ares, pilotos e cubanos em seus MiG-23 engajavam caças sul-africanos. Estes foram os mais abatidos, o que permitiu reduzir sensivelmente o poder aéreo sul-africano. (LIBERATTI, 1999, p. 89-90).

Se durante a década de 1980, durante o governo do MPLA, é desalentadora a realidade angolana, na década seguinte novos episódios tornam-se marcos no cenário político do país, consolidando o quadro que há algum tempo parecia em configuração. Em julho de 1990, o MPLA anuncia o abandono aos princípios do marxismo-leninisno que havia norteado o movimento por algum tempo e, a partir dessa mesma data, a constituição do país passa a permitir o pluripartidarismo, abrindo assim as negociações para as novas eleições que ocorreriam em setembro de 1992. Os anos iniciais de 1990 foram marcados, portanto, por um intervalo na guerra civil, com as negociações que 
ocorrem em 1991, quando são assinados os Acordos de Bicesse ${ }^{44}$. Às primeiras eleições angolanas concorrem diversos partidos que haviam se formado desde 1990, e os principais concorrentes para a presidência da república eram Jonas Savimbi (UNITA) e José Eduardo dos Santos (MPLA). Em outubro de 1992, os resultados apontam José Eduardo dos Santos para presidente, e ainda que tenha havido recontagem de votos, Savimbi não se conforma com esse resultado e a guerra estoura novamente, resultando em fortes ataques ao governo em dezembro de 1992 e janeiro de $1993^{45}$.

Em 1994, há novamente um acordo de paz, o Acordo de Lusaka, com a proposta de um "Governo de União e Reconciliação", no entanto, já a partir de 1997, a UNITA demonstra sinais de que estava apenas se recuperando militarmente para a guerra e em 1998 o governo é atacado novamente por uma UNITA reestabelecida. Em 1999, há ataques realizados a cerca de 100 quilômetros de Luanda, numa séria ameaça a essa zona urbana até então (de alguma forma) resguardada. O fim da guerra só acontece, finalmente, em 2002 e suas resultantes são catastróficas, como aponta Ruivo:

(...) por razões múltiplas e relativas à conjunção de diversos fatores não apenas externos, mas também internos, não somente não se construiu o socialismo em Angola, como também pouquíssimas conquistas sociais foram obtidas para a população. Assim, a situação angolana é, até os dias de hoje, de extrema pobreza e miséria da população. A guerra civil - alimentada constantemente por outros países, com destaque para os Estados Unidos - só terminou quando, em fevereiro de 2002, Jonas Savimbi, líder da UNITA, foi morto pelo exército governamental. A guerra, de acordo com um documento emitido pelo próprio governo angolano por ocasião da comemoração do terceiro aniversário do 4 de abril de 2002 (quando foi efetivamente acordada a paz), provocou aproximadamente 1 milhão de mortos e 100 mil pessoas tornaram-se deficientes físicos. Milhões de pessoas foram obrigadas a deixar suas casas e outras tantas a deixar o país, desestruturando famílias e os setores produtivos da nação. O território está repleto de minas - são aproximadamente 15 milhões - o que inviabiliza a agricultura em grande parte do solo angolano. A taxa de desemprego é ainda extremamente alta, fazendo com que $60 \%$ da população economicamente ativa esteja desempregada. A vida da população é ainda dificultada pela falta constante de água e de energia elétrica, problemas que até hoje se mantêm, bem como pela falta de moradia. A situação da a saúde e da educação é, também, caótica. (RUIVO, 2005, p. 191).

\footnotetext{
44 "Em $1^{\text {o }}$ de maio de 1991 são assinados os Acordos de Bicesse, entre MPLA e UNITA, com a intermediação de Portugal, Estados Unidos e União Soviética. O cessar-fogo é marcado para o dia 15 do mesmo mês e define-se que serão realizadas eleições livres no segundo semestre de 1992." (RUIVO, 2005, p. 190).

${ }^{45}$ Sobre isso, sugerimos a leitura de LIBERATTI (1999).
} 
Ainda com a brevidade desse apontamento histórico, o importante é notarmos que esse processo belicoso resulta num agravamento sensível das já precárias condições do país que se desenvolve a partir da Independência, ainda que as expectativas presentes antes da Guerra de Libertação apontassem para uma direção oposta. Não obstante à grave situação em que se encontra a maioria da população angolana, alguns dos homens que estão vinculados ao Estado abusam da proximidade com o poder para agir em benefício próprio, em detrimento da vasta camada popular em situação de miséria. É pois para esse quadro profundamente crítico que os narradores de A geração da utopia e Predadores olham durante suas narrativas, mas a equidistância que os separa é da temporalidade narrativa que os limitam e resulta em diferentes posturas que assumem.

Em A geração da utopia, os limites narrativos que circundam a obra, parecem, ao nosso entender, configurar a dificuldade de seu narrador em manter a mesma voz crítica ao longo do romance. Limitado a um tempo que vai da luta de libertação até 1992, ano das primeiras eleições angolanas, ele parece mergulhado nesse sentimento de perplexidade de quem ainda não acredita nas próprias observações e, uma vez liquidada a sua positividade, resta-lhe silenciar suas opiniões em detrimento de outras vozes que se adensam na narrativa. $\mathrm{O}$ autor implícito, à maneira que o conduz e apoiando-se no herói que se isola, parece apontar, ao mesmo tempo, para a perplexidade e para alguma possibilidade futura.

Nesse movimento, por exemplo, constrói a narrativa de maneira que na apresentação da década de 1980, que poderia apontar definitivamente para fratura do projeto de emancipação política de Angola cerceada pela constituição de uma nação com maior igualdade social, vincula seu narrador ao herói que, ainda que isolado na sua ilha física e emocional ${ }^{46}$, mantém-se íntegro e devidamente distanciado da disputa pelo poder. Aníbal não só se distancia das instâncias de poder como as nega, arguindo assim com o impulso ético que compõe sua personalidade desde o início da narrativa. E se a voz do narrador lhe cede a voz para suas análises realizadas em monólogos, diálogos, ou acompanhando o seu fluxo de consciência, acaba por dinamizar o seu isolamento e torna-lo a voz crítica ao cenário em composição no centro do poder político

\footnotetext{
46 "E o seu herói, após a queda de seu voo libertário, preserva sua integridade numa espécie de "ilha", um espaço aparentemente à margem do sistema, mas que paira por sobre a cabeça como identidade individual." (ABDALA Jr, in CHAVES; MACÊDO, 2009, p, 177)
} 
constituindo-se em Angola. O último capítulo, embora esteja mergulhado na descrente década de 1990, apontando para essa elite (burguesia subdesenvolvida) que se vai formatando e a perplexidade do narrador acaba por o calar, muito embora em seu auxílio venha um epílogo para pontuar as possibilidades que a continuidade histórica pode oferecer.

Temos então que limitado a esse tempo que narra, o narrador ascende ou decai de acordo com o momento que está incumbido de narrar, sua postura narrativa está, portanto, condicionada pelo tempo que lhe envolve a narração. Cala-se e passa de interventor a observador, da fala ao silêncio. Parece-nos que tal comportamento se dá exatamente porque dentro dos limites temporais expostos em obra, o narrador que vinha acompanhando o projeto de emancipação com o qual estava comprometido no primeiro capítulo não tem tempo hábil para lidar com o trauma produzido pelos novos rumos aportados no país independente e passa então, ele próprio a ser vetor desse trauma. Ao olhar para Malongo e Vítor (principalmente), no capítulo final, sua falta de perspectiva se amplia a tal ponto que seu amordaçamento parece inevitável. Não há, portanto, uma mudança brusca na postura narrativa há, pelo contrário, a continuidade de uma determinada intenção que, ao ser desenganada em suas positivas expectativas, não apreende um reposicionamento e perde a capacidade de redarguir a frustração do novo que surge.

Assim como Aníbal assiste a derrocada do projeto isolado em sua ilha, o narrador isola-se no ato de narrar. $\mathrm{O}$ autor implícito não se exime do seu posicionamento - mas o emaranhando que envolve seu herói e seu narrador acaba por revelar, parece-nos, algo sobre si próprio: ele observa aquela realidade consternado sem, no entanto, desacreditar na possibilidade de uma nova mudança de rumos e na retomada de um projeto idealizado outrora. E esse seu posicionamento parece também cerceado pelos limites temporais: no ano que finda a narrativa, embora Angola estivesse envolvida numa realidade difícil, conforme vimos, ainda havia a esperança lançada pelos novos acordos de paz proporcionados pela democracia que parecia, por fim, estabelecer-se.

A consequência mais evidente que a temporalidade narrativa causa no narrador e no autor implícito de Predadores, no entanto, é uma densidade irônica das vozes que remete para uma espécie de atitude desdenhosa para com a história que buscam narrar. Ora, se em A geração da utopia, o narrador emerge na narrativa fecundado por 
princípios da positividade e se desnorteia consternado com a negatividade evidenciada ao longo do processo narrativo que elabora, em Predadores o surgimento dessa voz narrativa surge através da observação de um cenário degradado, cuja análise aporta no negativo. A inscrição temporal denuncia um tempo de ressentimento (e não mais de perplexidade) daqueles que esperavam testemunhar um país socialmente mais igualitário e que, ao revés de suas expectativas, observam o estabelecimento de uma elite configurada aos moldes de seu protagonista.

O irônico narrador de Predadores divide com seu autor implícito a tarefa de desnudar o caráter do novo rico Vladimiro Caposso e apresentar um tempo marcado pelas sequentes frustrações para com o processo histórico que se vai constituindo e que, portanto, só poderia ser observado com uma voz crítica contundente e negativa daqueles que almejavam contar outra história. A violência inicial projeta todo o texto para a violência do tempo que será foco da narrativa e o autor implícito modela uma narrativa não linear, ampliando a confabulação irônica presente. $\mathrm{O}$ assassinato cometido por Vladimiro Caposso acontece paralelamente, como tivemos a chance de observar, às eleições que poderiam apontar para uma nova alternativa para Angola.

Mas o narrador se cola ao protagonista a fim de lhe denunciar o caráter e a violência se sobrepõe à comemoração, apontando assim para uma forte negatividade, ainda que o cenário externo a cena narrada pudesse ser positivo. A ironia cresce de acordo com o desenvolvimento da personagem de Caposso, como pudemos observar na análise separando as décadas narrativas. Quanto mais distante da época da luta de libertação, portanto quanto mais se caminha historicamente na narrativa para as décadas além da libertação e dos primeiros anos de governo, maior o grau de ironia do narrador e do autor implícito. Quer isso dizer que quanto mais distante daquele projeto idealizado nas bases do movimento de luta que precipitou a emancipação angolana, menor a afinidade de narrador e autor implícito com aquilo que se vai constituindo - a ironia, nesse contexto, aponta para isso.

E quanto mais ascende Caposso, mais taxativamente se voltam as vozes críticas para ele. Narrador e autor implícito não vacilam em suas vozes irônicas em nenhum momento e essa postura parece ser influenciada pelo cenário praticamente decomposto de valores de justiças e ética que buscam narrar quando próximos à elite da qual Caposso faz parte. Nem o tempo que aponta para o tão estimado final da guerra, anos 
2000, presente na narrativa, parece ser suficiente para acalentar essas vozes dizimadas pelo contrário, no jogo de disputa pelo capital, se há possibilidade de saída de cena de Vladimiros Capossos, a substituição não aponta para uma perspectiva positiva ao apresentar estrangeiros como Karim ou Omar, sedentos em dar continuidade (talvez de maneira mais arguta) as empreitadas anteriores. O que narrador observa, portanto, o desalentador processo que se segue em Angola a partir do cessar-fogo da guerra de libertação até o advento dessa parcela da população e, diante desse quadro estabelecido, das expectativas frustradas, da desgraçada realidade da maior parte da população, não resta a essas entidades outra alternativa senão o olhar negativo proporcionado pelo distanciamento que tomam daquilo que narram através da ironia.

Há, então, uma dissonância entre as vozes de A geração da utopia e Predadores constituída, principal e fortemente, pela dimensão temporal que nelas são elaboradas. No entanto, se esses narradores e autores implícitos são circunstanciados pela história e apresentam atitudes narrativas equidistantes, o mesmo não ocorre com relação ao viés ideológico que parece os nortear. A mesma medida que o processo histórico resvala em suas oratórios, caracterizando-as pela positividade/perplexidade ou pela negatividade/ironia, a ideologia os aproxima, uma vez que esses diferentes posicionamentos apontam, ao fim, para um único horizonte. Há, portanto, uma similitude entre esses narradores e autores implícitos que não podemos ignorar: todos eles estão suplantados em um universo crítico que ascende os mesmos pressupostos ideológicos. Para tanto, é importante que nos voltemos para tais pressupostos evidenciados por essas vozes.

\subsection{Vozes consonantes: a presença da dimensão ideológica}

Alguém que fosse totalmente vítima da ilusão ideológica sequer seria capaz de reconhecer uma reivindicação emancipatória sobre si; e é porque as pessoas não param de desejar, lutar e imaginar, mesmo nas condições aparentemente mais desfavoráveis, que a prática da emancipação política é uma possibilidade genuína.

(EAGLETON, 1997, p. 13). 
$\mathrm{Na}$ tentativa de identificar o ponto de vista formatador das vozes do narrador e do autor implícito dos romances estudados, fomos levados a analisar a conjuntura histórica que se desdobra em obra enquanto tempo narrativo apontando para uma dissonância entre essas vozes e chegamos, por fim, a uma questão determinante que aproxima essas entidades: a ideologia. Para tanto, buscaremos sintetizar o conceito na medida correspondente aos limites compatíveis ao nosso locus teórico e a nossa investigação, o qual não corresponderia, (e nem poderia ambicionar) evidentemente, um levantamento da ideologia enquanto conceito filosófico, já tão amplamente discutido ${ }^{47}$. Ainda que saibamos dos riscos de se reduzir a conceitualização, tal redução parece-nos única forma de perscrutar o ponto de vista dessas vozes, cuja ideologia aparentemente desponta como um caminho fundamental de sua percepção.

Condicionando a discussão que aqui propomos dessa forma, torna-se importante que frisemos que para esta pesquisa importa o papel da ideologia perante a existência de conflitos sociais e que, portanto, decretar o fim da ideologia ou apontar apenas para a negatividade do conceito não é um caminho que pretentedemos percorrer. Para tanto, embasamo-nos nas observações de István Mészáros :

\begin{abstract}
Prever o "fim da ideologia" ou atribuir uma conotação apenas negativa a toda ideologia sempre foi algo totalmente irrealista e continuará sendo por um longo período histórico. É inconcebível que as ideologias "murchem" por si - e, muito menos, que sejam ficticiamente "superadas" no âmbito fechado de construções teóricas pseudo-científicas - enquanto existirem conflitos sociais importantes com os quais estão inextricavelmente interligadas. (MÉSZÁROS, 2012, p. 109).
\end{abstract}

Dentre as diversas funções que aportam no conceito, uma revela-se fundamental para esta dissertação, a ideologia tem um papel integrador na constituição de um grupo, segundo nos aponta Konder:

Certas tomadas de consciência só podem se verificar através de um código ideológico. Nenhum indivíduo e nenhum grupo podem desenvolver uma reflexão total e tematizar tudo como objeto de pensamento. A ideologia, então, desempenha um papel essencial na integração, na constituição de cada grupo, atendendo à sua demanda por uma representação simbólica própria. (KONDER, 2002, p. 165).

\footnotetext{
47 "Existem poucos conceitos na história da ciência social moderna que sejam tão enigmáticos e polissêmicos como esse de ideologia." (LÖWY in KONDER, 2002, p. 9).
} 
O que podemos identificar nas vozes pepetelianas as quais compete a narração dos romances em análise é que elas corroboram de um mesmo código ideológico, integrando-se, portanto, a um mesmo grupo de reinvindicações. São dois os pilares que sustentam essa integração e é sobre eles que pretendemos nos debruçar. O primeiro diz respeito ao que podemos chamar de ideologia socialista. Sobre isso, Mészáros nos esclarece:

O papel vital da ideologia socialista, como negação radical da ordem estabelecida, consiste precisamente em identificar e ajudar a ativar, através de sua orientação abrangente, todas aquelas mediações potencialmente libertadoras e que tenham a capacidade de transcender essa ordem, mediações que, sem sua ativa intervenção, permaneceriam adormecidas e dominadas pelo poder do isolamento da imediaticidade, gerenciada e manipulada pela ideologia dominante. (MÉSZÁROS, 2012, p. 239).

Nesse sentido, é possível notarmos que tanto narrador e autor implícito de $A$ geração da utopia quanto de Predadores posicionam-se contra uma determinada ordem dominante, para seguir as palavras de Mészáros, uma ideologia dominante. No primeiro caso, contestam a ideologia relacionada ao colonialismo, ou seja, aquela exercida pelo colono, como ficou posto na análise do primeiro capítulo do romance. Por outro lado, em Predadores, as vozes que narram posicionam-se contra a ideologia vinculada a uma espécie de ordem capitalista, representada por aqueles que formam uma burguesia angolana em ascensão, tal qual tentamos evidenciar.

Se, no entanto, essa postura anti ideologia dominante é facilmente identificável no posicionamento das entidades narrativas, há um segundo pilar que sustenta essa posição ideológica condicionado, parece-nos, àquilo que foi a configuração da ideologia do próprio MPLA, movimento ao qual, é importante frisar, Pepetela esteve por muito tempo ligado, e que vai se apresentar como questão central no ponto de vista das vozes. No que concerne à ideologia socialista, é importante notarmos que ela própria fez parte, por algum período, da formação ideológica do Movimento, o que aponta para uma possível sobreposição da ideologia do MPLA sobre qualquer outra ideologia presente nas vozes. Nesse sentido, torna-se imprescindível que voltemos nossa atenção para a base de formação dessa ideologia buscando, mais uma vez, o respaldo do processo 
histórico que determina a proposta do $E m e^{48}$, atentando para as condições históricas que contribuíram para sua formação, o que nos leva de volta aos tempos coloniais.

Embora os portugueses cheguem em territórios africanos por volta do século $\mathrm{XV}$, por muito tempo houve no então futuro território angolano ${ }^{49}$ uma exploração colonial voltada para o tráfico de escravos, o que resultou numa ocupação portuguesa delimitada a áreas costeiras como Luanda e Benguela "e em determinados eixos no sentido litoralinterior como é o caso do corredor Luanda-Malanje" (BITTENCOURT, 2008, p. 42). Entretanto, após a abolição da escravatura $(1878)^{50}$, ocorre uma reorganização do sistema colonial em Angola, com crescente ocupação portuguesa e a forma de exploração do trabalho se modifica. Dessa maneira, constitui-se a nova forma de trabalho compulsório (cujos trabalhadores seriam conhecidos como contratados) e o confisco (resultante do considerável aumento dos impostos imputados por Portugal, para substituir o lucro advindo da escravidão).

Com a intensificação da presença portuguesa, iniciada a partir do século XIX, mas consideravelmente expandida no século XX, ocorre em Angola uma ocupação que era, como nos alerta Bittencourt (2008, p. 42) não só militar - cujo ápice foi a chegada da $\mathrm{PIDE}^{51}$, nos anos de 1950 - mas também física e econômica. A partir dessa intensificação da presença portuguesa, cuja resultante é um importante fortalecimento da exploração das forças de trabalho, o definitivo enfraquecimento político e econômico e perda de espaço por parte dos grupos formados principalmente por mestiços e negros "assimilados", cuja cultura estava ligada a cultura europeia portuguesa ${ }^{52}$, vão surgir nas

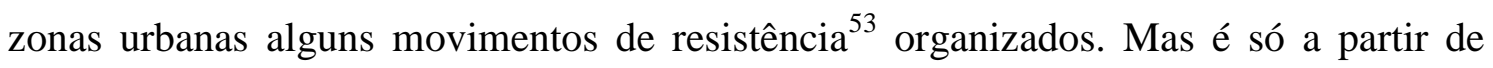
1948, com a articulação de Instituições Culturais e Revistas, que aparecem as primeiras organizações políticas, das quais nasceria o MPLA.

\footnotetext{
${ }^{48}$ Segundo Bittencourt, forma como "seria carinhosamente chamado o MPLA". (2008, p. 63)

${ }^{49}$ Oficialmente constituído a partir da conferência de Berlim, no século XIX.

${ }^{50}$ Importante apontar que falamos de uma modificação predominante, ainda que continuasse existindo as caravanas clandestinas de escravos.

${ }^{51}$ Polícia Internacional de Defesa do Estado (Português).

52 Sugerimos aqui a leitura de BITTENCOURT (2008) que associa esse grupo a questão crioula em Angola, definindo, em linhas gerais, o crioulo como o sujeito que tinha ligação tanto com a matriz cultural europeia quanto com a matriz cultural africana.

${ }^{53}$ É importante destacar que os movimentos de resistência existiram desde o século XV, com a chegada dos portugueses. Intensificaram-se à medida que se intensificou a presença portuguesa; prova disso são as Guerras de Pacificação que passam a ocorrer a partir do século XIX, numa tentativa portuguesa de calar a resistência angolana. No entanto, essa resistência ocorria sem ser de forma politicamente organizada. Sobre isso, ler BITTENCOURT (2008).
} 
A PIDE chega em Angola com o objetivo de desintegrar as organizações. Vale ressaltar que a sua presença no país é resultado também da política de censura a movimentos que contrariassem a ditadura salazarista, que tem início em Portugal a partir de 1932.

A posição política pública de Salazar e dos salazaristas influiu enormemente nos territórios ultramarinos, sustentada pela estrutura ultramarina mantida sobre bases ideológico-culturais predominantemente fundadas na ideia do Império Português, com missões expansionistas e de conversão dos "pagãos" ao catolicismo. Neste sentido, o colonialismo da fase salazarista aprofundou as mudanças impostas desde meados do século XIX, sobretudo no que dizia respeito a uma maior centralização administrativa e consequente enfraquecimento político, econômico e social das elites do corredor Luanda-Malange, refletindo-se no rigo da política alfandegária em busca de um equilíbrio financeiro para a metrópole. (ARAÚJO, 2005, p. 30).

É importante ressaltarmos que, a partir do cenário que se organiza com a chegada da PIDE, as atuações tanto da UPA quanto do MPLA tomam novas formas, até eclodirem os levantes na Revolução iniciada em 1961. Sobre as diversas e significativas divergências ocorridas entre a UPA e o MPLA durante esse período não iremos nos deter. Assim como não nos deteremos às questões intrínsecas às oposições entre os três movimentos MPLA, FNLA - que é originária da própria UPA - e UNITA, que culminam na guerra civil, porque consideramos que essas questões, ainda que sejam de extrema importância para compreensão da questão angolana, bem como da questão das produções artísticas de Pepetela, tangenciam e nos distanciam dos objetivos propostos em relação à discussão que pretendemos efetuar a partir daqui. No entanto, cabe ainda lembrar e enfatizar a oposição que o MPLA faz a esses dois outros movimentos, e essa oposição, sem dúvida, incidirá sobre a sua própria ideologia.

Nascido no "seio de uma elite intelectual, formada a partir de Luanda" (ARAÚJO, 2005, p. 45), o MPLA, ao longo de sua história passou por diversos períodos de rupturas, cuja importância se revela nas novas adequações pelas quais o partido vai atravessando ao longo dos anos. Ainda que sejam relevantes essas adequações, atentemos para o que delas resvala nas vozes narrativas de A geração da utopia e Predadores. As condições de seu surgimento combinam fatores que se tornam relevantes para a formação de sua ideologia. 
Na década de 1960, o mundo estava dividido em uma disputa bipolar entre dois blocos - representados principalmente por EUA, de um lado, e URSS de outro. A bipolaridade mundial reflete em Angola e se a UPA encontra apoio nos EUA para a luta colonial, o MPLA, necessariamente, irá ser apoiado pela URSS ${ }^{54}$. Para além do discurso que o aproximava de certa maneira do bloco que apoiava, estavam presentes na direção do MPLA intelectuais que haviam frequentado os PCs (Partidos Comunistas) europeus e que formulam uma ideia de nação baseada então nas propostas de Stalin, como nos alerta Araújo:

No caso de Angola, e de muitos outros países africanos e asiáticos que conheceram a independência tardiamente, em meio à bipolaridade mundial, a opção pelo alinhamento político-ideológico com o bloco socialista incorporou o discurso sobre o que seria uma nação elaborado por Joseph Stalin, em 1912, como comunidade estável com linguagem, vida econômica, território e caracterização psicológica própria, manifestando-se assim numa comunidade cultural. (ARAÚJO, 2005, p. 73).

A ideia de comunidade cultural - já então implantada nas bases político ideológicas do MPLA e muito presente durante a luta de libertação, estará profundamente articulada à ascensão do partido ao governo, resultando na elaboração de um ideal de homem para a nova nação em formação, tratando-se da configuração do chamado homem novo angolano. Portanto, o novo homem angolano deveria apresentar algumas características fundamentais que o distiguiria dos homens de outro tempo, sublimados pelo colonizador. O primeiro passo fundamental para essa modificação é o reconhecimento de pertencimento a uma determinada cultura endógena que deve se opor, impreterivelmente, à cultura do colono que lhe fora anteriormente imposta como superior compondo a intrínseca unidade contraditória entre colonizador e colonizado. Assim, o sentimento de identidade nacional seria imprescindível para a arguição à luta e a disposição de combater. Forja-se dessa maneira, mesmo antes da precipitação da luta de libertação, nas entranhas do MPLA, a ideia de que, independente das origens étnicas, regionais e/ou raciais, todos os angolanos fazem parte de uma única e indivisível comunidade cultural que deveria opor-se ao seu opressor, qual seja os portugueses.

\footnotetext{
54 "Se por um lado, a UPA consolidava sua ligação com os Estados Unidos da América, através de uma administração Kennedy muito falante sobre os temas africanos, o MPLA dificilmente poderia encontrar outro ancoradouro que não fosse Moscovo. Mesmo assim, o movimento trilhou um caminho lento e por vezes reticente até que se firmasse a conexão.” (BITTENCOURT, 2008, p. 144).
} 
Os intelectuais à frente do MPLA perceberam que a consciência nacional devia ser forjada na luta, pois uma vez alcançada a independência e rompidos os laços com o colonialismo, o novo Estado que iria se constituir sobre novas bases, teria como fonte de legitimação as diversas comunidades humanas que viviam em território, e estas deveriam reconhecer-se não somente como nação territorial, mas também identificar-se como comunidade política participante de um projeto de nação, aqui entendida como um "tipo muito nítido de sentimento e sensibilidade de lealdade e identificação”. (ARAÚJO, 2005, p. 69).

O novo homem angolano se constitui assim como um artefato político e é nesse sentido que nos será fundamental para a identificação de algumas características da ideologia presentes no movimento. Podemos apontar, portanto, as noções básicas que formulam essa ideologia: a ideia do socialismo como o caminho necessário estará, de alguma maneira e ainda que não totalmente no plano das ações políticas, posta na formação dos homens que participam e formam o grupo do MPLA. Para além disso, defende-se uma universalidade, na tentativa de homogeneizar o homem angolano - em detrimento a considerável diversidade étnica, regional e racial presente do país - cujo interesse principal é a elaboração de uma ideia de identidade que despertasse a consciência nacional fundamental para o adensamento da luta de libertação.

Há também a questão da intelectualidade inerente ao locus no qual nasce o Movimento, mas que sofre alguma modificação a partir da primeira ruptura ocorrida internamente, no início da década de 1960, entre Agostinho Neto e Viriato da Cruz. Ainda que haja aspectos importantes a serem apontados quando se pretende adentrar essa discussão, para a formulação da ideologia que buscamos apresentar nas vozes dos narradores, o fator principal a ser considerado é que a partir dessa ruptura, o que será defendido dentro do MPLA (com a permanência fortalecida de Agostinho Neto como presidente do Movimento) é a defesa de um ideal de intelectual com participação efetiva na luta, numa proposta que visava uma aproximação entre os dirigentes e a base do MPLA. Os fatores presentes durante a luta de libertação irão se tornar propostas fundamentais a partir da ascensão do movimento ao governo, e assim sendo, temos que:

Desde a independência, em 1975, que se propagava um ideal de nação unificada, que tendia a homogeneizar o homem angolano através da politização da sociedade entendida como um todo, uma vez que esta deveria ser portadora de uma cultura científica, popular e revolucionária, assim como o novo homem angolano estar a serviço da revolução social. Aí ser criada a Direção Nacional de Massificação 
Cultural, o Estado elaborou um discurso que teve como ponto de partida a cultura nacional, mas nele a identidade política tornou-se hegemônica em relação às demais identidades. (ARAÚJO, 2005, p. $80)$.

Necessário se faz ressaltar ainda que se o Estado imprimia esse discurso com relação à nova nação em formação, um forte contraste se desenhava entre o discurso elaborado e a realidade da população ${ }^{55}$, não só no que diz respeito às expectativas dos angolanos, mas também a contrastante divergência entre mundo ideal pretendido pelo partido e a difícil realidade vigente. Nesse sentido, exige-se por exemplo, que o homem angolano não tivesse um pensamento reacionário e, para tanto, que não fosse enraizado em suas particularidades étnicas, raciais ou regionais, enquanto o que se acompanha, mesmo dentro do próprio movimento, é um evidente conflito fomentado também por essa diversidade.

Impõe-se, pois, a necessidade de olhar para os narradores e autores implícitos dos romances aqui estudados atentando para essa composição ideológica formulada no interior do Movimento. Pepetela se envolve com o MPLA a partir da década de 1960, quando se encontrava em Lisboa, no curso técnico. Sua participação no movimento tem fim quando ele sai do Ministério da Educação em dezembro de 1982. Portanto, durante pelo menos duas décadas, Pepetela esteve fortemente ligado ao MPLA. Dessa maneira, não podemos ignorar que suas tendências ideológicas foram de certa forma moldadas por sua participação no Movimento. E nesse caso temos que ainda que haja a crítica lúcida às opções do partido, ela está respaldada por uma visão ulterior, embasada na concepção do MPLA que respinga nas vozes que narram os romances em análise.

Tanto em A geração da utopia quanto em Predadores vemos algumas dessas formulações destacadas na ideologia do MPLA como componente significativa da estruturação das vozes que narram e é essa característica central que irá aproximar essas vozes, ainda que as condições temporais que apresentam sejam diferentes resultando em posturas narrativas distantes, como já observamos.

\footnotetext{
55 "A procura por uma identidade que unisse a diversidade partiu sempre de cima, das aspirações dos intelectuais, não representando necessariamente as aspirações, esperanças, necessidades ou mesmo entendimento dos diversos grupos humanos como elementos que partilhavam uma mesma realidade territorial e política, sendo que algumas vezes nem no interior de um mesmo movimento havia congruência de aspirações e reinvindicações." (ARAÚJO, 2005, p. 76)
} 
Autor implícito e narrador de A geração da utopia aproximam-se, evidentemente, do herói da narrativa, que configura o que poderíamos chamar de espécie de homem ideal, de acordo com o projeto do MPLA para o homem novo angolano, por apresentar algumas das características importantes na composição de sua personalidade. Primeiro é notável que Aníbal fulgure a intelectualidade no romance e essa sua qualidade não é restrita só a si, mas compartilhada pelo autor implícito que questiona o antigo professor - herói e autor implícito, portanto, definem-se logo de início como intelectuais. Existe, no entanto, um posicionamento marcante dessa intelectualidade - Aníbal é um intelectual que se aproxima da base do próprio partido e aporta no segundo ato narrativo como guerrilheiro. O autor implícito, em sua revelação explícita na primeira página, também se volta para a ação, opondo-se ao professor e para isso escrevendo um romance iniciado pela expressão outrora criticada. Portanto, para além da intelectualidade, estão em sintonia com o que se esperava dos intelectuais que iriam formar a nova nação, conforme as premissas que configuram o partido com Agostinho Neto na presidência. Aníbal eleito como personagem central, torna-se assim o balizador das atitudes das outras personagens, é nele que narrador e autor implícito se colam e é através da proximidade que estabelecem com sua personagem que iluminam o ponto de vista da narrativa.

Por seu turno, em Predadores a mesma aproximação ocorre no que diz respeito à configuração da personagem de Sebastião Lopes. Intelectual comprometido com a base, Sebastião vai para o front, frustra-se, luta para tentar reaver no Movimento os antigos ideais que se decompõem no cenário pós-Independência. Condenado a um isolamento político, por não comungar os novos valores do partido, torna-se advogado e atende uma população desprivilegiada pelo sistema vigente no país, firmando-se dessa forma também como intelectual comprometido com a população. Narrador e autor implícito sempre que próximos a Sebastião perdem a ironia e, dessa maneira, constroem uma identificação que os aproxima dessa personagem. O intelectual aqui, portanto, também tem papel fundamental e fulgura como uma das oposições a Caposso. Nacib, outro opositor do protagonista, também possui certa intelectualidade, uma vez que sua ascensão social está ligada a construção de seu conhecimento por esforços pessoais. No entanto, a ele resta ainda outra função que demonstra a segunda particularidade que aponta para a ideologia das vozes: o dinheiro para Nacib assume um valor diferente ao 
de Caposso, tornando-se um bem passível de divisão ${ }^{56}$, apresentando assim uma noção mais coletiva, menos individual.

Adentramos então no terreno da coletividade que respalda a universalidade ${ }^{57}$ proposta de certa maneira pelas vozes que contam essas histórias. As personagens das quais essas vozes se aproximam, por uma espécie de cumplicidade, vias de regra estão envolvidas com a coletividade que transpassa e se sobrepõem às suas individualidades. É o caso de Sara, desde o início de $A$ geração catalisadora da construção de um projeto de coletividade. É também o caso de Sebastião Lopes, como acabamos de apontar. Ainda que em certa medida, assim se apresenta Nacib, pois que seu projeto de crescimento através do conhecimento é voltado também para a satisfação de outros membros de sua família (como sua mãe) e para ajudar o amigo. O contrário disso, ou seja, a insatisfação dos narradores e autores implícitos com aqueles cujos projetos individuais são mais significativos também é notável, e temos, dessa forma, que se afastam, por exemplo, - através da entonação irônica - de Vítor se transformando em Mundial, isolado na floresta de batalha, articulando sua ascensão em meio ao delírio e de Mireille com sua ambição de "consumidora de museus".

A universalidade paira de uma maneira ainda mais intrínseca nessas vozes, porque sequer é evidenciada qualquer discussão étnica, racial e regional, ainda que nas entrelinhas vez ou outra tenhamos a chance de verificar que a questão está presente ${ }^{58}$. Ainda assim, mesmo quando as particularidades étnicas e/ou regionais são levantadas acabam sendo tangenciadas pela carga negativa que comportam ${ }^{59}$. Sendo assim, Vítor apoia-se à questão étnica de maneira oportunista para ascender dentro da guerrilha, apenas porque lhe parece, de acordo com o contexto que se desenha, pertinente assumir tal posicionamento. Tal movimentação lhe amplia o caráter negativo que desde o início

\footnotetext{
${ }^{56}$ Como fica claro em seu diálogo final com Kasseke.

${ }^{57}$ Fazemos menção com esse termo ao que pertence ao universo angolano, tentando com ele referir-nos a grande diversiddea étnica, regional e racial presente no país.

${ }^{58}$ Como exemplo, temos o caso de Malongo em território português, ou com a questão ética da qual busca se beneficiar Vítor e Caposso.

${ }^{59}$ Notemos, no entanto, que em Mayombe, escrito na frente de batalha, os guerrilheiros apontam para as particularidades étnicas, raciais e regionais abrindo a discussão para a necessidade de superação de tais pontos.
} 
de A Chana se vai construindo. Caposso segue caminho parecido, ao apoiar-se à questão regional para conseguir angariar alguma vantagem nas esferas de poder do MPLA ${ }^{60}$.

Portanto, a restrição da universalidade que ocorre quando as particularidades étnicas ou regionais ou raciais são assumidas assume um viés negativo nas vozes que narram e ficam sempre condicionadas ao campo da ironia, ligando-se apenas às personagens que estão submersas a esse campo. No entanto, as personagens das quais narradores e autores implícitos se aproximam tem suas identidades ancoradas na universalidade angolana. Aníbal, então, torna-se, enquanto homem ideal, o vetor máximo da ausência de etnia ou de apego regional, uma vez que não sabemos sequer qual o seu local de origem. Algo parecido ocorre com Sara, Nacib e Sebastião Lopes. Poderíamos argumentar, entretanto, que essas personagens são urbanas, quase todas moradoras de Luanda, o que de certa forma poderia diminuir seus vínculas étnicos ou regionais, mas ainda que assim o fosse, parte delas são originárias de locais menos urbanizados, como Malongo e Vítor, o que não precipita a discussão para a questão pautada. ${ }^{61} \mathrm{O}$ fato é que posta assim na estruturação narrativa, a universalidade em contraposição às particularidades étnicas, raciais e regionais encaminha a nossa análise para um outro espaço de construção ideológica que se organiza nas obras: a consciência nacional.

Além, portanto, da intelectualidade, da coletividade e da universalidade presentes, como pretendemos apontar até agora, um elemento essencial para a elaboração dessas vozes narrativas é a presença incontestável de certa identificação das personagens com a angolanidade, ou, se preferirmos, com a ideia de consciência nacional. Diante disso, autores implícitos e narradores, eles próprios, assumem como uma de suas características centrais o fato de serem angolanos, evidenciando essa identidade em contraposição a qualquer outra, principalmente em oposição àquelas que de alguma maneira são opressoras. A geração da utopia é inaugurada dessa forma, quando para além das personagens, o autor implícito destaca a própria voz para se opor ao professor português, fazendo uso, para início de um romance, de uma expressão condenada por aquele, fortalecendo dessa forma o locus do ponto de vista, qual seja: Angola. O

\footnotetext{
${ }^{60}$ É notável, no entanto, que essas personagens se apercebam que tal posicionamento não lhes angariaria grandes fortunas - Vítor rapidamente se desvincula da questão étnica quando percebe o problema que lhe poderia causar e Caposso se arrepende de ter optado por Catete em sua nova identidade.

${ }^{61}$ Ainda poderíamos ressaltar que mesmo em Parábola do Cágado Velho, cujo enredo se passa inteiro no seio de uma aldeia, a etnia ou regionalidade não se torna tema central, o que pode apontar para a sublimação dessa questão no projeto artístico de Pepetela que excede o corpus ficcional desta pesquisa.
} 
narrador também se posiciona e nesse sentido apresenta como duplo narrativo Sara, e seu fluxo de consciência que desperta para essa identidade - ser angolana em contrariedade ao ser português. Por toda a narrativa, essa construção permanece e poderíamos apontar como auge de nossa percepção sobre esse evento o fato de que nenhuma personagem, sequer Malongo, cuja postura desde o início desperta desconfiança no narrador, tem qualquer dúvida sobre sua identidade angolana em contraposição à identidade europeia ${ }^{62}$.

A consciência nacional também está presente nas vozes de Predadores e podemos observá-la em algumas passagens em que o autor implícito se sobrepõe ao narrador, vociferando suas próprias impressões acerca dos eventos que estão sendo narrados. Em muitas das passagens, coloca-se como testemunha de uma determinada realidade, a angolana, fazendo também com que seu locus enunciativo fique bastante evidente ${ }^{63}$. No entanto, destaquemos um ponto que parece enaltecer a nacionalidade das vozes narrativas: ainda que todo o enredo se volte para a crítica a tipos como Caposso, que representam uma burguesia nacional, existe uma menção a negatividade que a presença de estrangeiros apura a essa burguesia. Ou seja, ainda que Caposso tenha uma postura antagonista àquela almejada por narrador e autor implícito, ele está adistrtito a nacionalidade angolana e, portanto, sua negatividade será suplantada por outra ainda maior: Karim e Omar são "tubarões ainda maiores”, capazes de uma atuação maléfica na realidade de Angola que supera a de Caposso. Além do foco narrativo, é notável também a confrontação que se dá quando as personagens estão em território estrangeiro, como a família Caposso em Paris ou o jovem Nacib nos EUA, o que acaba por colocar em destaque a identidade angolana em contraposição a outras identidades.

Se em A geração da utopia o colonizador português é o opressor com relação ao qual a identidade angolana irá se opor, confabulando suas particularidades, em Predadores os estrangeiros que ameaçam explorar o país constituem também uma identidade oposta

\footnotetext{
62، Não admitia é que os europeus lhe viessem com lições. (...) Não viessem por isso armar em professores de pacifismo só porque desde a hecatombe de meados do século não tinha uma guerra a sério na Europa. Aprenderam mas é a fazê-las longo de casa, quem se lixa é o quintal do outro. (...) Não, os europeus não tinham lições a dar a ninguém, até porque os trinta anos de guerra em grande parte (na maior) tinha sido provocados por eles.” (PEPETELA, 2013, p. 315)

63 "O tal congresso que ficaria na História como o mais ortodoxo de todos os realizados e o culminar das guerrilhas internas para a absoluta centralização da autoridade." Ou ainda: "Um ano depois recomeçaria a guerra e as previsões dele eram portanto tão falsas com os seus conhecimentos geográficos" (PEPETELA, 2008, p. 339; 343). A esses exemplos seguem diversos outros.
} 
a identidade nacional de Angola. Nesse sentido, podemos dizer que há na estruturação das vozes narrativas que encaminham o enredo nesses romances o espectro da consciência nacional, cujo papel desempenha função singular, tornando-se uma característica fundamental na entoação dessas vozes.

Em O Inconsciente Político, o crítico americano Fredric Jameson defende a tese de que nada existe que não seja social e histórico, e assim, portanto, decorrentemente, que não seja político, e propõe dessa maneira a investigação de um inconsciente político:

A defesa de um inconsciente político propõe que empreendamos justamente essa análise final e exploremos os múltiplos caminhos que conduzem à revelação dos artefatos culturais como atos socialmente simbólicos. (JAMESON, 1992, p. 18).

Jameson aponta ainda para a necessidade de uma análise realizada com mediação, e justifica:

A mediação é o termo dialético clássico para o estabelecimento de relações entre, digamos, a análise formal de uma obra de arte e seu chão social, ou entre a dinâmica interna do Estado político e suas bases econômicas. (...) a vida social é, em sua realidade fundamental, una e indivisível, uma rede inconsútil, um processo único, inconcebível e transindividual, em que não há necessidade de se inventarem modos de conectar os fatos da linguagem e as convulsões sociais ou as contradições econômicas porque, nesse nível eles nunca estiveram desligados uns dos outros. (idem, p. 35-36).

Ao concordarmos com o ponto de vista de Jameson, faz-se importante ressaltarmos que, ainda que Pepetela elabore suas vozes narrativas com diferentes posturas devido ao locus temporal presente em obra, com uma delineação histórica que as vai moldando e diferenciando, há evidentemente uma esfera dessa produção que condiz com o locus ideológico no qual ocorreu a formação do próprio autor, mas mais do que isso, o locus ideológico que se sobrepõe em Angola a partir do advento do MPLA ao governo do país. Se não nos cabe qualquer julgamento moral acerca desse locus, fica como dever em nossa análise apontar para a existência dele, tal como intentamos fazer durante este último capítulo da dissertação. Se concordamos ainda que não há ato que não seja político, concordamos também que ainda um ato político pode-se fazer através de um inconsciente embalado pela transindividualidade. Nas palavras de Benjamin Abdala Jr. : 
Quando o escritor escreve, pode julgar que o texto é apenas seu, não tendo consciência de que na verdade é a sociedade que se inscreve através dele. Na sua escrita está uma confluência de práxis coletivas, desde a específica da série literária até às outras, relativas à sua atividade noutros campos sêmicos do trabalho social. O escritor engajado procura ter consciência dessa inserção social. (...) É também um trabalho literário a apropriação da cultura, de sentido políticosocial, mas que o sujeito não domina plenamente. A polissemia da matéria artística escapa-lhe do controle. (ABDALA Jr, 2007, p. 45).

Nesse sentido, o que as vozes narrativas de Pepetela acabam por revelar é que possuem um ponto de vista compatível com o ponto de vista do autor, mas principalmente compatível com um ponto de vista da sociedade que o cerca. Assim sendo, temos que ainda que numa esfera mais superficial sejam evidentes os alvos de seus dedos em ristes, em suas entrelinhas configura-se certa dimensão ideológica que parece fugir da obviedade para revelar ao leitor um movimento social que está ali configurado. Transbordam dessas vozes certos aspectos contraditórios presntes e é por esse motivo que a voz do narrador de $A$ geração, a princípio tão participativo, cala-se. A presença da contradição de ações do próprio movimento lhe toma a voz crítica - atônito, o narrador só observa.

Se em Predadores há certa linearidade da postura das vozes que contam, parece-nos que é porque o distanciamento temporal lhes deu a chance de exercer a crítica, revestindo-se de ironias. No entanto, no cerne da narração irônica, encontramos também a contradição presente do processo histórico que respinga na elaboração narrativa. Vladimiro Caposso ascende não apenas por méritos próprios no universo da malandragem política, mas também porque há uma conjunção de fatores sociais, revelados pelos próprios narradores, que acabam, de certa maneira, por possibilitar e quiçá justificar as ações dessa personagem. E ainda que não haja empenho dessas vozes em apontar para essa contradição enquanto revelam os atos de Caposso, é na movimentação que fazem ao redor dele na narrativa (com Nacib, Kasseke, Simão e tantos outros) que apontam para a intensa dificuldade da luta de angolanos pela sobrevivência, fator que parece contribuir de maneira significativa para a formação do caráter desse protagonista.

Diante disso, temos que esses narradores e autores implícitos possuem em sua estruturação uma ideologia que os aproxima, fazendo com que suas vozes, movimentando-se em direção consonantes. Compartilham a visão de mundo e logo 
narram a partir de um mesmo ponto de vista, independente da conjugação temporal que lhes seja elaborada.

$\mathrm{Na}$ verdade, a ideologia não é ilusão nem superstição religiosa de indivídos mal-orientados, mas uma forma específica de consciência social, materialmente ancorada e sustentada. (...) Os intersses sociais que se desenvolvem ao longo da história e se entrelaçam conflituosamente manifestam-se, no plano da consciência social, na grande diversidade de discursos ideológicos relativamente autônomos (mas, é claro, de modo algum independentes), que exercem forte influência sobre os processos materiais mais tangíveis do metabolismo social. (MÉSZÁROS, 2012, p. 65).

Atentando para essas palavras de Mészaros, poderíamos afirmar que se essas vozes que contam nos dois romances de Pepetela apresentam uma ideologia compartilhada, circunscrita numa mesma consciência social e que se, entretanto, o diferente plano histórico que as condicionam aponta para uma dissonante postura narrativa, o plano ideológico para o qual apontam as colocam em atitude consonante.

\section{CONSIDERAÇÕES FINAIS}

Ao propormos um diálogo entre os narradores e autores implícitos das obras $A$ geração da utopia e Predadores fomos levados a investigar alguns aspectos estruturantes dessas vozes que narram nas obras de Pepetela: a condição histórica para a qual apontam ao fecharem-se em um determinado locus temporal que, por sua vez, aponta para uma determinada dimensão ideológica na composição que as estrutura. Por esse caminho, a pesquisa nos orientou a entender que havia uma dissonância entre as vozes e, ao mesmo tempo, uma consonância entre elas.

Fechadas num tempo histórico singular, combinam características que emergem da aproximação que fazem das personagens eleitas. Sendo assim, quando próximas daquelas com as quais não possuem uma afinidade ideológica, afastam-se; do contrário, aproximam-se. Esse movimento, possibilitado principalmente pela densidade irônica que assumem, foi determinante para que pudéssemos escolher os caminhos que seguimos na busca do locus enunciativo dessas vozes. 
Ao investigarmos a história de Angola circunscrita às linhas dos romances, pudemos verificar que o condicionamento dos narradores estava estreitamente ligado ao horizonte que alicerça suas vozes. O distanciamento do período que marca a memória dos angolanos como período de guerra de libertação, a época da luta, resulta nessa alternância de postura narrativa. Assim temos que quanto mais próxima a narrativa está da luta de libertação (caso de $A$ geração), mais positividade encontramos nas vozes que narram os romances, pelo seu contrário, quanto mais distante os fatos narrados estão desse período (Predadores), maior a carga negativa presente no ato de narrar.

Se em A geração da utopia o espaço temporal proposto é da guerra de libertação até as primeiras negociações da guerra civil, temos um narrador que observa num primeiro momento com entusiasmo as possibilidades vislumbradas no futuro, colado na utópica Sara, respaldado pelo herói Aníbal e que depois, ao fim da narrativa, torna-se letárgico devido à perplexidade provocada pelos rumos tomados no pós-independência. $\mathrm{O}$ horizonte do narrador de Predadores, no entanto, está definido por um tempo recortado a partir das negociações para a independência até o fim oficial da guerra civil. Nessas condições, sua alternativa é tornar-se irônico para postular definitivamente seu incômodo e o distanciamento entre si e a história que se propõe narrar.

Assim, as marcas da diferenciação do tempo da história são fundamentais na estruturação das vozes narrativas de A geração da utopia e Predadores e definem as suas singularidades. Se a postura dos narradores se diferencia, também a postura de seus autores implícitos será diferente. Num primeiro momento de entusiasmo, o autor implícito de $A$ geração da utopia se apresenta para dar mais vazão à disposição para a luta, presente em todo o primeiro capítulo. Ao calar a sua voz, "prudente e definitivamente" (PEPETELA, 2013, p. 9) aproveita-se da sua posição de autoridade para dar amplas condições de fala ao seu herói, que passa então a ser o respaldo do narrador consternado. Nas condições em que se desenvolve a narrativa de Predadores, o autor implícito assume uma voz autônoma, recorrente e desafiadora, apresentando a si mesmo como respaldo do narrador e, mais importante, como contraponto da autoridade do anti-herói cuja história é desvelada na narrativa.

Aportadas, no entanto, em outra dimensão que as condicionam, as vozes se tornam consonantes. A ideologia que revelam as situa num mesmo campo de integração e reinvindicação: essas vozes se desenham opositoras dos caminhos que certa ideologia 
dominante desenhou para o país. Se a primeira opõe-se ao colonialismo, a segunda confrontará a nova elite que se estabelece no país pós-independência. A ideologia que possuem é evidenciada na postura narrativa que assumem principalmente com relação às suas personagens, afastam-se ou aproximam-se à medida em que apontam para a presença ou ausência de afinidades. Essas vozes são afins daqueles que parecem representar o ideal do homem novo projetado nos tempos de libertação pelo MPLA. Portanto, nesse momento da investigação, arriscamos dizer que a ideologia que as define é a ideologia do próprio partido, no início de sua formação, como procuramos apontar.

Diferentes vozes, dois romances, um mesmo projeto artístico-literário. Pepetela, dessa maneira, reafirma em sua escritura a preocupação com a história que, ao ser refletida a partir de certo filtro ideológico, acaba por estruturar-se à maneira que nos propomos a expor nesta dissertação. Firma-se assim o compromisso do escritor com o processo histórico do país. Firmam-se assim características que circundam e entoam suas vozes narrativas.

Mas o que o escritor tem a fazer é chamar a atenção, levar as pessoas a refletir sobre certas coisas. Penso que esse é o papel do filósofo. $O$ escritor, no fundo, é um filósofo... Ou então invetar mundos que não existem, mas baseando-se na própria (PEPETELA in CHAVES, 2009, p. 37) realidade. 


\section{REFERÊNCIAS BIBLIOGRÁFICAS}

ABDALA JUNIOR, Benjamin. Literatura, História e Política. São Paulo: Ateliê Editorial, 2007.

De vôos e ilhas. São Paulo: Ateliê Editorial, 2003.

ADORNO, Theodor W. Notas de Literatura I. São Paulo: Duas Cidades, 2003.

ANDERSON, Benedict. Nação e consciência nacional. São Paulo: Ática, 1989.

ANDERSON, Perry. Portugal e o fim do ultracolonialismo. Rio de Janeiro: Civilização Brasileira, 1966

ARAUJO, Kelly Cristina Oliveira de. "Um só povo, uma só nação": o discurso do Estado para a construção do homem novo em Angola (1975-1979). 2005. 122 f. Dissertação (Mestrado em História)-Faculdade de Filosofia Letras e Ciências Humanas, Universidade de São Paulo, 2005.

AUERBACH, Erich. Mimesis. São Paulo: Perspectiva, 2002.

BALANDIER, George. As dinâmicas sociais: sentido e poder. São Paulo: Dief, 1976.

BAKHTIN, Mikhail. Questões de literatura e de estética. São Paulo: Hucitec Editora, 2010

BARTHES, Roland. Análise estrutural da narrativa. Petrópolis: Editora Vozes Ltda, 1971.

BENJAMIN, Walter. Obras Escolhidas I. 2. ed. São Paulo: Brasiliense, 1987.

BITTENCOURT, Marcelo. "Estamos Juntos" o MPLA e a luta anticolonial (19611974). Luanda: Kilombelombe, 2008. 2 v.

BLOCH, Ernest. O princípio esperança. Rio de Janeiro: EDUERJ: Contraponto, 2005.

BOOTH, Wayne. A retórica da ficção. Lisboa-Portugal: Ateliê Arcádia, 1980.

BOSI, Alfredo. Dialética da colonização. São Paulo: Companhia das Letras, 1992. 
Ideologia e Contraideologia. São Paulo: Companhia das Letras, 2010.

Literatura e resistência. São Paulo: Companhia das Letras, 2002.

BOXER, Charles Ralph. O império marítimo português 1415-1825. São

Paulo: Companhia de Letras, 2006.

BRAIT, Beth. Ironia em perspectiva polifônica. Campinas: Ed. UNICAMP

BRUNNACCI, Maria Isabel. Gracilano Ramos: um escritor personagem. Belo Horizonte: Autêntica Editora, 2008.

CANDIDO, Antonio. Literatura e Sociedade. Rio de Janeiro: Ouro Sobre Azul, 2006.

. O discurso e a cidade. 4. ed. São Paulo: Ouro Sobre Azul, 2010.

Tese e antítese. Rio de Janeiro: Ouro sobre azul, 2006.

CHAUÍ, Marilena de Souza. O que é ideologia? São Paulo: Brasiliense, 2009.

CHAVES, Rita de Cássia Natal. Angola e Moçambique: experiência colonial e territórios literários. São Paulo: Ateliê editorial, 2005.

. Formação do Romance Angolano: entre intenções e gestos. São Paulo: FFLCH-USP, 1999.

; MACEDO, Tânia. (Org.). Portanto... Pepetela. São Paulo: Ateliê Editorial, 2009.

CHAVES, Rita; MACÊDO, Tania; VECCHIA, Rejane (Org.). A Kianda e a Missanga.

São Paulo: Cultura Acadêmica; Luanda: Nizla, 2007.

EAGLETON, Terry. et al. Ideologia. São Paulo: Boitempo, 1997.

Nationalism, colonialism, and literature. Minneapolis: Universidad of Minnesota Press, 2001.

Teoria da Literatura: uma introdução. São Paulo: Martins Fontes, 2006.

ERVEDOSA, Carlos. Roteiro da literatura angolana. Luanda: União dos Escritores Angolanos, [199-?]. 
FANON, Frantz. Os condenados da terra. Rio de Janeiro: Civilização Brasileira, 1979.

DAL FARRA, Maria Lucia. O narrador ensimesmado. São Paulo: Ática, 1978.

FERRO, Marc. História das colonizações. São Paulo: Companhia das Letras, 1996.

GUERRA, Henrique. Angola: estruturas econômicas e classes sociais. Luanda: União dos Escritores Angolanos, 1988.

GOLDMANN, Lucien. A sociologia do romance. Rio de Janeiro: Paz e Terra, 1976.

GRAMSCI, Antonio. Os intelectuais e a organização da cultura. Rio de Janeiro: Civilizações Brasileira, 1978.

HERNANDEZ, Leila Leite. A África na sala de aula. São Paulo: Selo negro, 2005.

HAMILTON, Russell. Literatura africana literatura necessária. Lisboa: Edições 70, 1983.

HOBSBAWN, Eric. A invenção das tradições. Rio de Janeiro: Paz e Terra, 1984. Nações e nacionalismo desde 1780. 5. ed. São Paulo: Paz e Terra, 2008.

HUTCHEON, Linda. Teoria e política da ironia. Tradução Julio Jeha. Belo Horizonte: Ed. UFMG, 2000.

JAMES, Henry. Pelos olhos de Maisie. São Paulo: Companhia das Letras, 2010.

JAMESON, Fredric. $O$ inconsciente político: a narrativa como ato socialmente simbólico. São Paulo: Ática, 1992.

KAYSER, Wolfgang. Análise e interpretação da obra literária. Coimbra: Armênio Amado Editora, 1985.

KI-ZERBO, Joseph. História da África negra. Lisboa: Europa-América, 2002. 2 v.

KONDER, Leandro. A questão da ideologia. São Paulo: Companhia das Letras, 2002.

LABAN, Michel. Angola: encontro com escritores. Porto: Fundação Eng. António de Almeida, 1991. 
LEÃO, Angela Vaz. (Org.) Contatos e ressonâncias: Literaturas africanas de Língua Portuguesa. Belo Horizonte: PUCMINAS, 2003.

LEITE, Ana Mafalda. Literaturas africanas e formulações pós-coloniais. Lisboa: Edições Colibri, 2003.

LIBERATTI, Marco Antonio. A guerra civil em Angola: dimensões históricas e contemporâneas. 1999. 145 f. Dissertação (Mestrado em História)-Faculdade de Filosofia, Letras e Ciências Humanas, Universidade de São Paulo, São Paulo, 1999.

LOURENÇO, Eduardo. A nau de Ícaro: seguido de imagem e miragem da lusofonia. Lisboa: Gradiva, 2004.

LUBBOCK, Percy. Técnica da ficção. São Paulo: Cultriz/EDUSP, 1976.

LUKÁCS, Georg. A teoria do romance. São Paulo: Editora 34, 2009. Marxismo e teoria da literatura. São Paulo: Expressão Popular, 2010.

MACÊDO, Tania Celestino. Angola e Brasil: estudos comparados. São Paulo: FFLCHUSP, 2002.

Os anos de pólvora: ficção, história e memórias em narrativas de Angola e Moçambique. Belo Horizonte: ANPOLL, 2008.

MARGARIDO, Alfredo. Estudos sobre literaturas das nações africanas de língua portuguesa. Lisboa: Sodilivros, 1980.

MARX, Karl; ENGELS, Friedrich. A ideologia alemã. São Paulo: Boitempo, 2007.

MEMMI, Albert. Retrato do colonizado precedido do retrato do colonizador. Rio de Janeiro: Paz e Terra, 1977.

MÉSZÁROS, István. Filosofia, ideologia e ciência social. São Paulo: Ensaio, 1993. O poder da ideologia. São Paulo: Boitempo, 2012.

MORAES, Dênis de. Combates e utopias: os intelectuais num mundo em crise. Rio de Janeiro: Record, 2002. 
MORETTI, Franco (Org.). A cultura do romance. São Paulo: Cosac Naify, 2009.

MOURÃO, Fernando Augusto Albuquerque. A sociedade angolana através da literatura. São Paulo: Ática, 1978.

MUNANGA, Kabengele. África: trinta anos de processo de independência. Revista da USP, São Paulo, n. 18, p. 102-111, jun./ago. 1993. Disponível em: http://www.usp.br/revistausp/18/09-kabengele.pdf Acesso em: 8 dez. 2013.

NITRINI, Sandra. Literatura comparada. São Paulo: EDUSP, 2000.

PEPETELA. A geração da utopia. São Paulo: Leya, 2013.

. Jaime Bunda: o agente secreto. Rio de Janeiro: Record, 2003. . Mayombe. São Paulo: Ática, 1982.

. Muana Puó. Lisboa: Publicações Dom Quixote, 1995.

. O cão e os caluandas. Lisboa: Publicação Dom Quixote, 1985.

O quase fim do mundo. 2. ed. Lisboa: Dom Quixote, 2008.

Parábola do Cágado Velho. Rio de Janeiro: Nova Fronteira, 2005.

Predadores. Rio de Janeiro: Língua Geral, 2008.

ROSENFELD, Anatol. Texto e contexto. São Paulo: Perspectiva, 1975.

RUIVO, Marina. Literatura e Resistência: estudo comparado de viagem à luta armada, de Carlos Eugênio da Paz, e a geração da utopia, de Pepetela. 2005. 285 f. Dissertação (Mestrado em Estudos Comparados de Literaturas de Língua Portuguesa)-Faculdade de Filosofia, Letras e Ciências Humanas, Universidade de São Paulo, São Paulo, 2005.

SAID, Edward W. Cultura e política. São Paulo: Boitempo, 2007. Representações do intelectual: as conferências de Reith de 1993. São Paulo: Companhia das Letras, 2005.

SANTILLI, Maria Aparecida. Africanidades. São Paulo: Ática, 1975. 
SECCO, Lincoln. A revolução dos cravos. São Paulo: Alameda, 2004.

WILLIAMS, Raymond. Cultura e sociedade: 1780-1950. São Paulo: Editora Nacional, 1960. 